PNL-6488

UC-70

\title{
Characterization of Unsaturated Hydraulic Conductivity at the Hanford Site
}

M. L. Rockhold

M. J. Fayer

C. W. Gee

July1988

Prepared for the U.S. Department of Energy under Contract DE-AC06-76RLO 1830

Pacific Northwest Laboratory

Operated for the U.S. Department of Energy

by Battelle Memorial Institute 


\section{DISCLAIMER}

This report was prepared as an account of work sponsored by an agency of the United States Government. Neither the United States Government nor any agency thereof, nor Battelle Memorial Institute, nor any or their employees, makes any warranty, expressed or implied, or assumes any legal liability or responsibility for the accuracy, completeness, or usefulness of any information, apparatus, product, or process disclosed, or represents that its use would not infringe privately owned rights. Reference herein to any specific commercial product, process, or serviceby trade name, trademark, manufacturer, or otherwise does not necessarily constitute or imply its endorsement, recommendation, or favoring by the United States Government or any agency thereof, or Battelle Memorial Institute. The views and opinionsof authorsexpressedherein do not necessarilystate or reflect thoseof the United States Government or any agency thereof, or Battelle Memorial Institute.

\section{PACIFIC NORTHWEST LABORATORY \\ operated by \\ BATTELLE MEMORIAL INSTITUTE \\ for the \\ UNITED STATES DEPARTMENTOF ENERGY \\ under Contract DE-AC06-76RLO 7830}

\begin{tabular}{|c|c|}
\hline \multicolumn{2}{|c|}{$\begin{array}{c}\text { Printed in the United States of Americ } \\
\text { Available from } \\
\text { National Technical Information Servi } \\
\text { United States Department of Commer } \\
5285 \text { Port Royal Road } \\
\text { Springfield, Virginia 22161 }\end{array}$} \\
\hline \multicolumn{2}{|c|}{$\begin{array}{l}\text { NTIS Price Codes } \\
\text { Microfiche A01 }\end{array}$} \\
\hline \multicolumn{2}{|c|}{ Printed Copy } \\
\hline Pages & $\begin{array}{l}\text { Price } \\
\text { Codes }\end{array}$ \\
\hline 001-025 & $\mathrm{A} 02$ \\
\hline $026-050$ & $\mathrm{~A} 03$ \\
\hline $051-075$ & A04 \\
\hline $076-100$ & A05 \\
\hline $101-125$ & $A 06$ \\
\hline $126-150$ & A07 \\
\hline $151-175$ & $\mathrm{~A} 0 \mathrm{~B}$ \\
\hline $176-200$ & A09 \\
\hline $201-225$ & $\mathrm{~A} 010$ \\
\hline $226-250$ & A011 \\
\hline $251-275$ & $\mathrm{~A} 012$ \\
\hline $276-300$ & $\mathrm{~A} 013$ \\
\hline
\end{tabular}


CHARACTERIZATION OF UNSATURATED HYDRAULIC CONDUCTIVITY AT THE HANFORD SITE

M. L. Rockhold

M. J. Fayer

G. W. Gee

July 1988

Prepared for the U.S. Department of Energy under Contract DE-AC06-76RLO 1830

Pacific Northwest Laboratory Richland, Washington 99352 


\section{EXECUTIVE SUMMARY}

The quantification of water movement in the unsaturated zone is an objective of the Hanford Site Performance Assessment Program, sponsored by the U.S. Department of Energy. This program is being conducted by the Pacific Northwest Laboratory (PNL) and Westinghouse Hanford Company. To accomplish this objective, PNL has undertaken a study to evaluate methods for measuring and predicting unsaturated hydraulic conductivities. This report details some recent field measurements and compares predicted and measured values of hydraulic conductivities for three locations at the Hanford Site.

Measurements from small (6-cm-dia.) "point" and large (2-m by 2-m) "plot" areas utilized infiltration and drainage techniques to obtain in situ data for field-saturated and unsaturated hydraulic conductivity. The Guelph permeameter was used for point sampling, and the unsteady drainage-flux method was used on plots for field-saturated and unsaturated hydraulic conductivity measurements. Steady-state techniques were used to measure unsaturated hydraulic conductivities in small columns in the laboratory for one of the three soils tested to provide a comparison with data obtained from the field.

The sandy soil at the Buried Waste Test Facility near the 300 North Area burial grounds yielded hydraul ic conductivity values that ranged over five orders of magnitude $(6 \times 10-3$ to $9 \times 10-8 \mathrm{~cm} / \mathrm{s})$. These values represent a water content range from field saturation to "field capacity" (i .e., well drained), corresponding to values of 0.303 and $0.096 \mathrm{~cm}^{3} / \mathrm{cm}^{3}$, respectively. The laboratory and field measurements agree within a factor of five for the range of measured values. A power function relationship describes the fieldmeasured hydraulic conductivity data fairly well for typical water contents observed in the field.

The Grass site is approximately $3 \mathrm{~km}$ southwest of the Buried Waste Test Facility. The soil profile at the Grass site is layered, with loamy sand overlying sand. Hydraulic head data indicate that lateral spreading of water in the upper layers of soil occurred during the drainage phase of the experiment at this site. Calculations of hydraulic conductivity by the unsteady drainage-flux method assume one-dimensional (vertical) flow. Therefore, data 
from the unsteady drainage-flux experiment at this site were not used to calculate unsaturated hydraul ic conductivities. The experiment was repeated with modifications to ensure one-dimensional (vertical) water movement, and these data are being evaluated.

The McGee Ranch is approximately $37 \mathrm{~km}$ northwest of the Buried Waste Test Facility. The unsteady drainage-flux method was used to calculate hydraulic conductivity for the fine (loam and silt loam) soil that occurs at this site. The unsaturated hydraulic conductivities at the McGee Ranch range from approximately $9 \times 10^{-4}$ to $8 \times 10^{-7} \mathrm{~cm} / \mathrm{s}$ over a water content range of 0.40 to $0.16 \mathrm{~cm}^{3} / \mathrm{cm}^{3}$, i.e., from field saturation to field capacity.

Measured unsaturated hydraulic conductivities and those predicted from particle-size distribution and bulk density data agree within one-half to one and one-half orders of magnitude, depending on soil type. To use a particlesize distribution to estimate water retention characteristics and, subsequently, to predict unsaturated hydraulic conductivities, measurements of water-retention characteristics are necessary to determine a parameter value used in one of the models. Additional soil types would need to be analyzed to determine if a single value of the parameter can be used that will enable adequate prediction of hydraulic conductivities for the soil types of interest on the Hanford Site. If the predictive techniques can be refined and correlated with field measurements, unsaturated hydraul ic conductivities could be adequately estimated without actual field measurements. This information could then be used in the evaluation of potential remediation or disposal sites or for characterizing larger areas for recharge estimation.

No single method for measuring or calculating unsaturated hydraul ic conductivities is appropriate for all Hanford Site soils. Ideally, several methods should be used to take advantage of the strengths of each method, considering the data needs and resources avai lable. 


\section{ACKNOMEDGMENTS}

We would like to acknowledge John McBride, Paula Heller, and Randy Hayden of the Pacific Northwest Laboratory (PNL) for performing laboratory analyses used in this report. We also express special thanks to Tim Jones (PNL) for reviewing this document, and to Dr. James B. Sisson (Kansas State University) for helpful discussions. Thanks are also expressed to Chris Morgan (PNL) for word processing assistance. 


\section{CONTENTS}

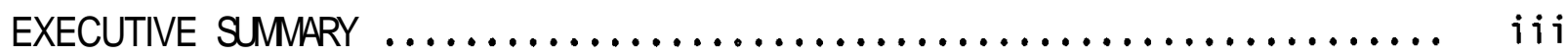

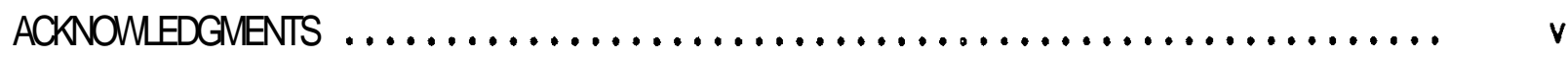

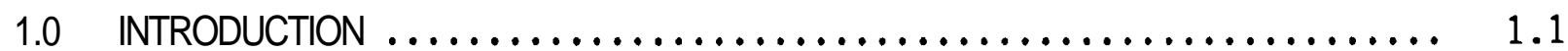

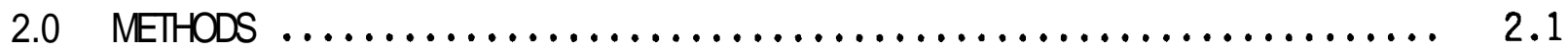

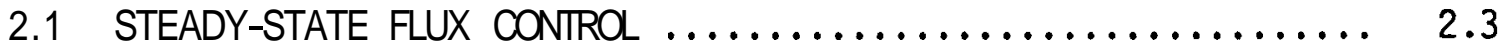

2.2 UNSTEADY DRAINAGE-FLUX $\ldots \ldots \ldots \ldots \ldots \ldots \ldots \ldots \ldots \ldots \ldots, 2.4$

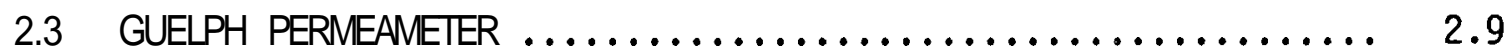

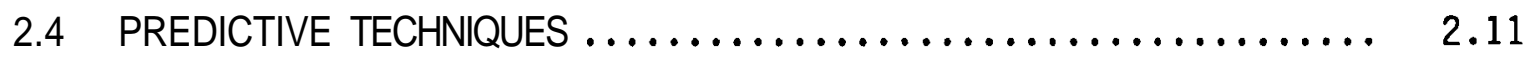

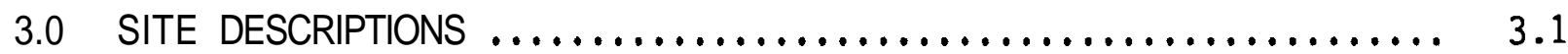

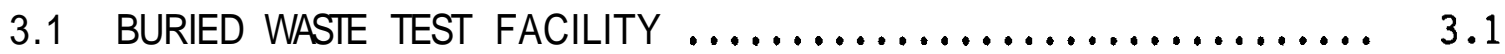

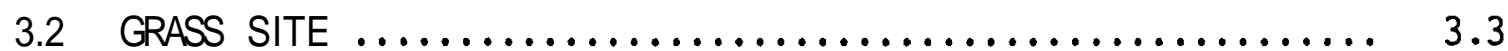

3.3 McGEE RANCH $\ldots \ldots \ldots \ldots \ldots \ldots \ldots \ldots \ldots \ldots \ldots \ldots \ldots \ldots \ldots, 3.4$

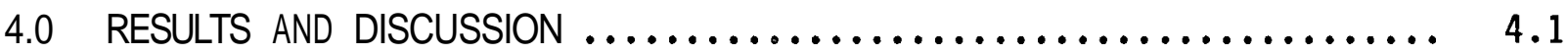

4.1 BURIED WASTE TEST FACILITY $\ldots \ldots \ldots \ldots \ldots \ldots \ldots \ldots \ldots \ldots \ldots, 4.1$

4.1.1 Steady-State Flux Control Method ................... 4.1

4.1.2 Unsteady Drainage-Flux Method ................... 4.1

4.1.3 Guelph Permeameter Method ....................... 4.14

4.1.4 Predictions ................................... 4.15

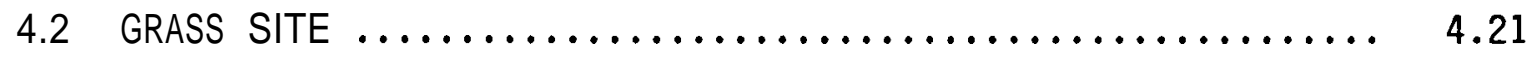

4.2.1 Unsteady Drainage-Flux Method .................. 4.21

4.2.2 Guelph Pemeameter Method ......................... 4.25

4.2.3 Predictions .................................. 4.26 
4.3 McGeE RANCH $\ldots \ldots \ldots \ldots \ldots \ldots \ldots \ldots \ldots \ldots \ldots \ldots \ldots \ldots \ldots \ldots, 4.26$

4.3.1 Unsteady Drainage-Flux Method ................... 4.26

4.3.2 Guelph Permeameter Method ..................... 4.29

4.3.3 Predictions ................................. 4.33

5.0 CONCLUSIONS AND RECOMMENDATIONS $\ldots \ldots \ldots \ldots \ldots \ldots \ldots \ldots \ldots \ldots \ldots . . \ldots .1$

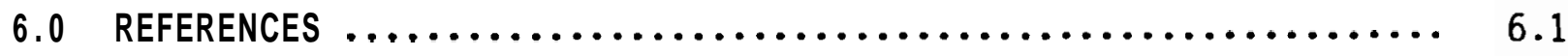

APPENDIX A - WATER RETENTION AND HYDRAULIC CONDUCTIVITY DATA ....... A.1

APPENDIX B - PARTICLE-SIZE DATA $\ldots \ldots \ldots \ldots \ldots \ldots \ldots \ldots \ldots \ldots \ldots \ldots \ldots \ldots \ldots \ldots \ldots \ldots$ 
FIGURES

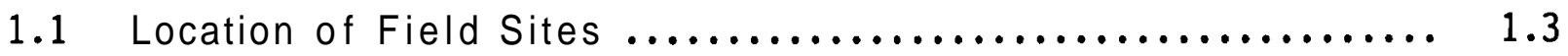

3.1 Soil Profiles at the Field Sites ......................... 3.1

3.2 Layout of the Buried Waste Test Facility Caissons $\ldots . . . \ldots \ldots .3 .2$

4.1 Measurements of Unsaturated Hydraulic Conductivity of L-Soil by the Steady-State Flux Control Method ................... 4.2

4.2 Water Content Profiles Observed During the Unsteady DrainageFlux Experiment in the Southeast Caisson .....................

4.3 Hydraulic Conductivity as a Function of Water Content from the Unsteady Drainage-Flux Experiment in the Southeast Caisson, from Repacked Columns in the Laboratory, and from the Lax Solution (Sisson, Ferguson, van Genuchten 1980) for the

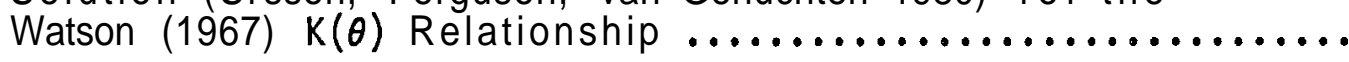

4.4 Depth ( $z$ )/Time ( $t$ ) Versus Water Content from the Unsteady Drainage-Flux Experiment in the Southeast Caisson ..............

4.5 Depth ( $z$ )/Time (t) Versus Scaled Water Content from the Unsteady Drainage-Flux Experiment in the Southeast Caisson ..... 4.8

4.6 Water Content Profiles Observed During the Unsteady DrainageFlux Experiment in the North Caisson

4.7 Hydraulic Head Profiles Observed During the Unsteady Drainage-Flux Experiment in the North Caisson

4.8 Hydraulic Conductivity as a Function of Water Content from the Unsteady Drainage-Flux Experiment in the North Caisson, from Repacked Columns in the Laboratory, and from the Lax Solution

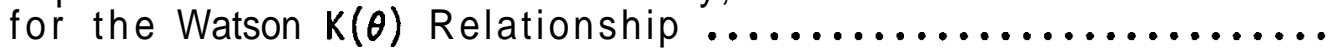

4.9 Hydraulic Conductivity as a Function of Matric Head from the Unsteady Drainage-Flux Experiment in the North Caisson, from Repacked Columns in the Laboratory, and the $K(h)$ Relationship Determined from the Average of 15 Sets of Guelph Permeameter Measurements at the Buried Waste Test Facility ............... 4.16

4.10 Water Retention Curves Fit to Data from the Unsteady DrainageFlux Experiment in the North Caisson and to Water Retention Characteristics Predicted by the Arya-Paris (AP) (1981) Model 
4.11 Hydraulic Conductivity as a Function of Water Content from the Unsteady Drainage-Flux Experiment in the North Caisson and Predicted Curves Based on the Arya-Paris (AP) (1981)

Model Results Shown in Figure 4.10

4.12 Water Content Profiles Observed During the Unsteady Drainage-

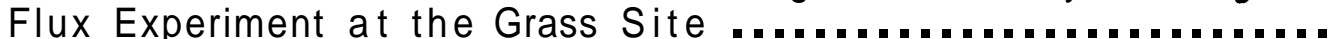

4.13 Water Retention Data from the Unsteady Drainage-Flux Experiment at the Grass Site.

4.14 Hydraulic Head Profiles Observed During the Unsteady Drainage-

Flux Experiment at the Grass Site ..........................

4.15 Water Content Profiles Observed During the Unsteady Drainage-

Flux Experiment at the McGee Ranch

4.16 Hydraulic Head Profiles Observed During the Unsteady Drainage-Flux Experiment at the McGee Ranch

4.17 Water Retention Data from the Unsteady Drainage-Flux

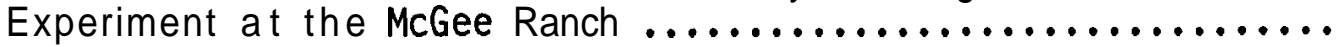

4.18 Hydraulic Conductivity as a Function of Water Content from the Unsteady Drainage-Flux Experiment at the McGee Ranch

4.19 Hydraulic Conductivity as a Function of Matric Head from the Unsteady Drainage-Flux Experiment at the McGee Ranch and the $K(h)$ Relationships Determined from the Average of 9 Sets of Guelph Permeameter Measurements at the McGee Ranch

4.20 Water Retention Curves Fit to Data from the Unsteady Drainage-Flux Experiment at the McGee Ranch and to Water Retention Characteristics Predicted by the Arya-Paris (AP) (1981) Model

4.21 Hydraulic Conductivity as a Function of Water Content from the Unsteady Drainage-Flux Experiment at the MoGee Ranch and Predicted Curves Based on the Arya-Paris (AP) (1981) Model Results Shown in Figure 4.20 


\section{$\underline{\text { TABLES }}$}

4.1 Results from the Guelph Permeameter for the Buried Waste Test

Facility

4.2 Curve-Fitting Results from the RETC.F77 Computer Program Based on Data from the Buried Waste Test Facility ..................

4.3 Results from the Guelph Permeameter for the Grass Site .........

4.4 Results from the Guelph Permeameter for the McGee Ranch ........

4.5 Curve-Fitting Results from the RETC.F77 Computer Program Based on Data from the McGee Ranch

A.1 Steady-State Flux Control Method Results for L-Soil ........... A.1

A.2 Water Content Data from the BWIF Southeast Caisson $\ldots \ldots \ldots \ldots$ A.2

A.3 Hydraulic Conductivity Data from the BWIF Southeast Caisson .... A.2

A.4 Water Content Data from the BWIF North Caisson ............... A.3

A.5 Matric Head Data from the BNIF North Caisson .................. A.3

A.6 Hydraulic Conductivity Data from the BWIF North Caisson ........ A.4

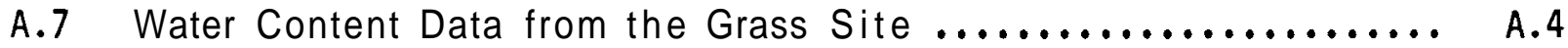

A.8 Matric Head Data from the Grass Site ....................... A.5

A.9 Water Content Data from the McGee Ranch ................... A.5

A.10 Matric Head Data from the McGee Ranch ..................... A.6

A.11 Hydraulic Conductivity Data from the McGee Ranch .............. A.7

B.1 Particle-Size Distribution Data from the Buried Waste Test Facility .......................................... B.1

B.2 Particle-Size Distribution Data from the Grass Site .......... B.3

B.3 Particle-Size Distribution Data from the McGee Ranch .......... B.5 


\subsection{INTRODUCTION}

Various disposal systems have been reviewed for the long-term disposal and isolation of hazardous wastes. At the Hanford Site, one concern is that water draining through the unsaturated sediments may carry contaminants to the water table. A fundamental property of the unsaturated sediments that controls the rate at which water transports contaminants is the hydraulic conductivity (U.S. Department of Energy 1987, Appendix M) . For this reason, the Hanford Site Performance Assessment (HSPA) program is evaluating various procedures for measuring and predicting hydraul ic conductivities of soils at the Hanford Site. Although this report uses the term "soils", the methods outlined can be applied to most of the near-surface unsaturated sediments found on the Hanford Site. Note that this report considers the simple case where water is the only wetting fluid. Whenever multiphase flow and physicochemical interactions are significant, these methods must be modified.

The purpose of this report is to present the results of one research project that used three techniques to measure and one technique to predict unsaturated hydraulic conductivities of soils from three locations on the Hanford Site. Objectives of this study were not only to measure and predict unsaturated hydraul ic conductivities by various methods, but also to compare the methods and, if possible, determine which technique(s) provides the most reliable results.

For each measurement technique used, water flow was measured and the hydraulic conductivity calculated from the appropriate form of Darcy's Law. The technique used in this study for making measurements in the laboratory is a modification of the steady-state flux method of Klute and Dirksen (1986). The modification involved controlling the flux of water into the soil columns with equipment described by Wierenga et al. (1986). The techniques used for making measurements at the field sites included the unsteady drainage-flux method (Green, Ahuja, and Chong 1986) and the Guelph permeameter method (Reynolds and El rick 1985). The steady-state flux and unsteady drainage-flux methods have traditional ly been the most accurate techniques. Both techniques are relatively time consuming. Consequently, they may be impractical for making the large number of measurements needed to characterize areas 
(Ni el sen, Biggar, and Erh 1973). The Guel ph permeameter was used in addition to the other methods because of its speed, low-water-use requirements, and portability.

Methods of predicting unsaturated hydraulic conductivity rely on description of the water retention curve (WRC) rather than measurements of water flow. Mualem (1986) and van Genuchten (1978) describe many of these methods. A WRC relates the volumetric water content to the soil water potential. The WRC can be determined in the laboratory or in the field. Field measurements of water retention require more effort than laboratory measurements, especial ly for relatively dry conditions. An alternative to measuring water retention characteristics is to predict them from soil textural and structural properties. This can be done in a variety of ways, including multipie regression techniques that relate water contents at specified soil-water pressures to texture and bulk density (e.g., Hall et al. 1977; Gupta and Larson 1979).

In this study, prediction of water retention characteristics is based on an empirical model by Arya and Paris (1981) which also uses particle-size distribution and bulk density data. This type of analysis is potentially attractive for use at the Hanford Site because particle-size distribution data have already been collected from numerous test and observation wells (i .e., the Westinghouse Hanford Company grain-size data base).

This report provides hydraulic conductivity data for three test locations at the Hanford Site (see Figure 1.1) : 1) the Buried Waste Test Facility (BWTF), described by Phil lips et al. (1979) ; 2) the Grass site, described by Gee and Kirkham (1984); and 3) the McGee Ranch, described by Last et al. (1987). The methods used for measurements, predictions, and data interpretations of unsaturated hydraulic conductivity are presented in the sections that follow. Physical property data from the three test locations are provided in the appendixes. 


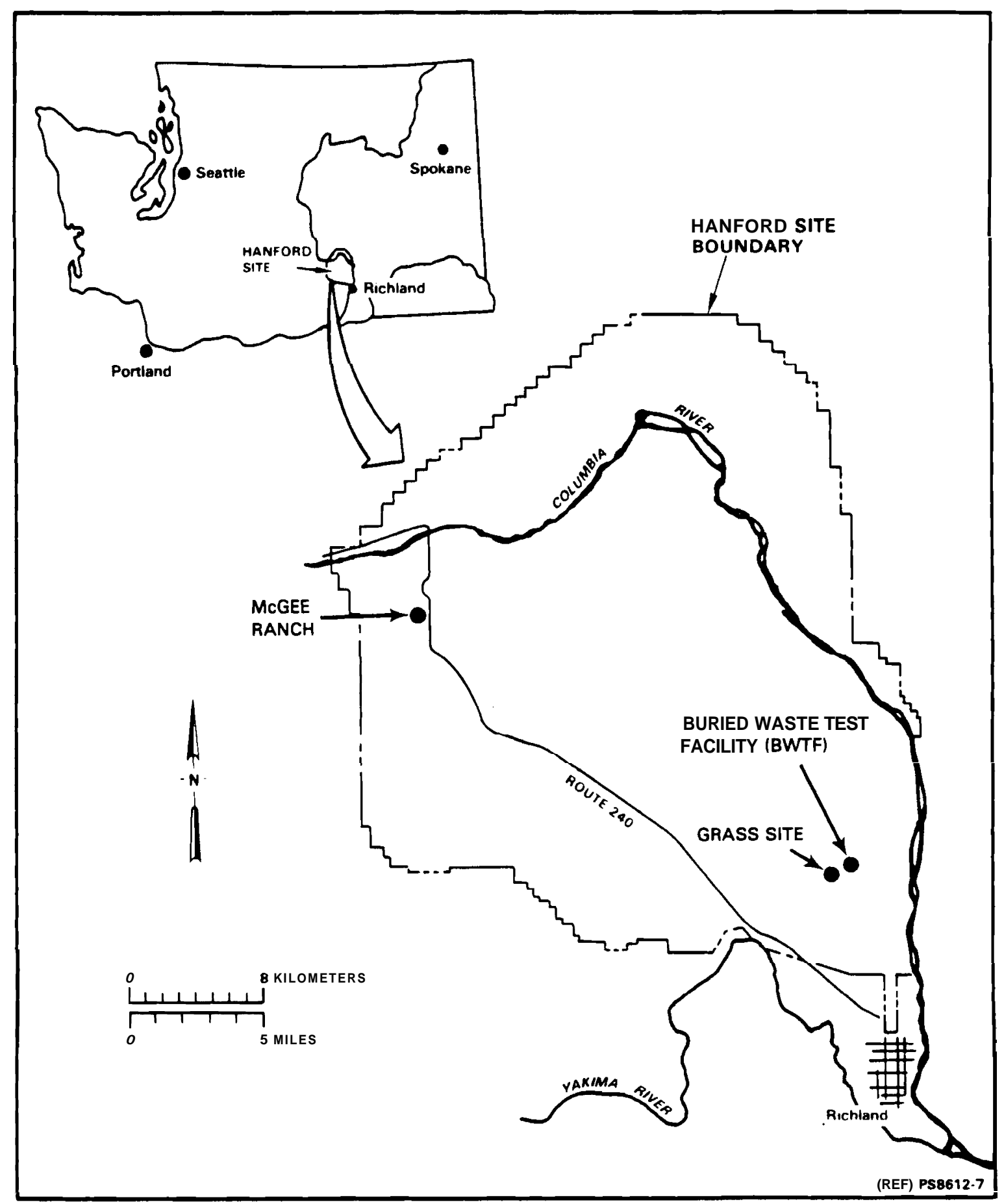

FIGURE 1.1. Location of Field Sites 


\subsection{METHODS}

Various methods have been developed for measuring the hydraulic conductivity of soils in the laboratory and field (Klute and Dirksen 1986). Field measurements are generally considered to be more representative of actual soil properties and conditions than laboratory measurements, but require more effort. Good agreement between field and laboratory data is often difficult to obtain because the natural soil heterogeneity of in situ soils is usually not represented in laboratory samples. Valid correlations are also made difficult by problems encountered in field studies, such as incomplete saturation, hysteresis effects, and preferential flow.

Methods that predict hydraulic conductivity based on particle-size distribution and bulk density data are generally easier to use than field or laboratory methods, but yield results with more uncertainties than those determined experimentally. These methods are usually based on simplifying assumptions and typically require a considerable amount of field or laboratory data for initial parameter estimation, and in order to make defensible predictions.

A problem affecting all methods is the attainment of a high degree of accuracy. In addition, no technique is completely reliable or adequately deals with all problems of measurement scale, spatial variability, and sample representativeness for all conditions. Consequently, the approach used in this study wi 11 be to compare the results of several techniques, and to use the results of the steady-state flux and unsteady drainage-flux methods as standards of relative accuracy.

To understand how various measurement techniques work, it is important to understand the processes controlling water flow in soil. Water moves in an unsaturated soil as liquid and vapor. Under isothermal conditions, water generally moves from regions of higher to lower potential energy. This potential energy, $\mathrm{H}$, can be expressed as

$$
H=h_{p}+h_{s}+h_{m}+h_{z}
$$


where $h_{p}=$ pressure potential

$h_{\mathbf{s}}=$ solute potential

$h_{m}=$ matric potential

$h_{\mathbf{z}}=$ gravitational potential.

Pressure potential represents external forces, such as water ponded on the surface of a field plot during the infiltration phase of an unsteady drainage-flux method experiment. Solute potential represents the attractive forces of water to higher solute concentration or osmotic forces. Matric potential represents the capillary and adsorptive forces which attract and bind water to the soil matrix. Gravitational potential is the energy associated with the location of water in the Earth's gravitational field, measured with respect to some reference point such as the soil surface. In most cases, pressure and solute potential are considered negligible. Consequently, the total potential, in the context of this report, is the sm of the matric potential, $\mathbf{h}(\mathbf{c m})$, and the gravitational potential (or vertical distance from the soil surface), $\mathbf{z}(\mathbf{c m})$. The sm of matric and gravitational potentials, when expressed on an equivalent height-of-water basis, is known as the hydraulic head. The total hydraulic head, as used in this report, consists of the matric head and the gravitational head.

The flux (q) of water through soil is proportional to the hydraulic head gradient $(\mathrm{dH} / \mathrm{dz})$. For saturated soils, the flux can be determined with the Darcy flow equation

$$
q=-K_{s} \frac{d H}{d z}
$$

where $K_{\mathbf{S}}$ is the saturated hydraulic conductivity (i.e., the proportionality factor). For unsaturated soils, the hydraulic conductivity is nonl inearly related to the matric head or water content. Equation (2.2) is usually modified to be

$$
q=-K(\theta) \frac{d H}{d z}
$$


where $\mathrm{K}$ is defined as the flux of water per unit gradient of hydraulic head and $\theta$ is the volumetric water content or volume of water per unit bulk volume of soil. To describe transient, vertical flow, Equation (2.3) must be combined with the equation of continuity

$$
\frac{\partial \theta}{\partial t}=-\frac{\partial g}{\partial z}
$$

where $\mathbf{t}$ is time and $\mathrm{z}$ is depth. This combination is commonly known as the Richards equation (Richards 1931).

$$
\frac{\partial \theta}{\partial t}=\frac{\partial}{\partial z}\left[K(\theta) \frac{\partial H}{\partial z}\right]
$$

\subsection{STEADY-STATE FLUX CONTROL}

Laboratory determinations of hydraul ic conductivities by the steadystate flux control method were made using the general method described by Kl ute and Dirksen (1986). The method was modified by control ling the flux of water into the soil columns with equipment described by Wierenga et al. (1986). An acrylic cylinder of known volume was packed with soil to a prescribed bulk density. The lower end of the cylinder was covered with a porous stainless steel plate (bubbling pressure $=245 \mathrm{~m} \mathrm{H}_{2} \mathrm{O}$ ) within an acrylic end cap. The end cap had a fitting to allow connection to a vacuum chamber. Rubber O-ring seals within the cap ensured an airtight seal between the cyl inder and the cap. The upper end of the cylinder was covered by an acrylic cap with a fitting that allowed connection to a syringe pump and solution reservoir. The top end cap was fitted loosely on the cylinder, so that the air above the soil was at atmospheric pressure. The acrylic cylinder had two tensiometer ports, at $5 \mathrm{~m}$ and $25 \mathrm{~m}$ above the stainless steel plate.

The syringe pump was adjusted to pulse a small volume of water at regular intervals to establish steady-state flow conditions through the soil column. The pulse volume was minimized and pulse frequency maximized to the 
extent possible. The starting point was a flux equal to the saturated hydraulic conductivity, with a unit gradient or hydraulic head difference equal to the distance between tensiometers $(20 \mathrm{~cm})$. To establish unsaturated condi. tions within the column, vacuum was applied to the vacuum chamber and the bottom of the column. The syringe pump was adjusted to reduce the flux of water into the top of the column, so that the fluxes entering and exiting the cylinder were equal. This steady-state condition was determined by monitoring the tensiometers with a TENSIMETER pressure transducer (Soi 1 Measurement Systems, 1906 South Espina, Las Cruces, NM 88001). When the readings of both tensiometers were equal, steady hydraulic flow and a uniform volumetric water content were assumed to exist (i .e., unit gradient conditions). For these unit gradient conditions, Equation (2.3) reduces to $q=-K(\theta)$ and the conductivity is equal to the input flux. The water content associated with the input flux (i .e., hydraulic conductivity) was determined by weighing the entire soil column. The reference weight for the soil column was the weight at approximately $100 \%$ saturation. As a datum check at the end of each experiment, the soil was removed from the column and oven dried to calculate a gravimetric water content. Applying higher suctions to the bottom of the column and reducing the input flux appropriately al lowed measurement of unsaturated hydraulic conductivities over the range of 0 to $-196 \mathrm{~cm}$ of matric head.

This method was only used for determining unsaturated hydraulic conductivities of L-soil (97\% sand, 2\% silt, 1\% clay), which is the laboratory designation for soil collected from the BWTF site in 1978 (Phillips et al. 1979; Cass, Campbell, and Jones 1981). Two repetitions with L-soil were conducted at each of two bulk densities, 1.6 and $1.7 \mathrm{~g} / \mathrm{cm}^{3}$. We assumed that these laboratory samples are texturally equivalent to samples subsequently collected from this site.

\subsection{UNSTEADY DRAINAGE-FLUX}

The unsteady drainage-flux method is based on Darcian analysis of transient in situ soil-water content and hydraulic head profiles during vertical drainage from field plots. The method, as used in this study, consisted of 
ponding water on the surface of a plot until the profile was wetted beyond the maximum depth of interest. The soil surface was then covered with clear plastic and a thin (approximately 3-cm-thick) layer of soil to prevent evaporation and to minimize thermal effects. Isothermal conditions were assumed to exist in the profile during drainage. Water contents and hydraulic heads were then monitored as the water in the profile redistributed and drained.

Ponding was facilitated by using existing caisson walls (e.g., at the BWTF site), using planking installed in narrow trenches around which soil was thoroughly compacted (e.g., at the Grass site), or by berming soil around the plot (e.g., at the McGee Ranch site). Water was supplied from an observation well via an electric pump at the BWTF site, and by hauling water by truck to the other two sites. Water contents were monitored with a model 503DR Hydroprobe (Campbell Pacific Nuclear Corp., 2830 Howe Rd., Martinez, CA 94553) inserted into steel or aluminum access tubes installed vertically in each plot. Matric heads were measured with tensiometers and a TENSIMETER pressure transducer.

Tensiometer and neutron probe readings were taken every 10 to $15 \mathrm{~min}$ during the initial drainage and redistribution phase of each experiment, and less frequently as time passed. The tensiometers were placed at 15- to 30-cm-depth increments, down to $180 \mathrm{~cm}$ at the BWTF and Grass sites and to $120 \mathrm{~cm}$ at the McGee Ranch site. All tensiometer measurements were referenced to the soil surface. Neutron probe readings were taken at depths corresponding to tensiometer placement, with the exception of the BWTF southeast caisson study, where no tensiometers were installed. Tensiometers were not installed in the southeast caisson because the caisson was not large enough to place them far enough away from the neutron access tube so that probe readings would not be affected by the water in the tensiometers. Volumetric water content was determined from neutron probe count readings by field calibrations at each site.

The unsteady drainage-flux method was first used for field measurements by Richards, Gardner, and Ogata (1956). Further developments in the method were made by Nielsen et. al (1964); Rose, Stern, and Drummond (1965); and 
Watson (1966). The actual computations of hydraulic conductivity used in this study are based on the time-averaging method used by Rose, Stern, and Drummond (1965), and the instantaneous profile method (after Watson 1966).

To obtain the value of $K$ at depth, $I$, Equation (2.5) can be integrated with respect to $z$, from the soil surface $(z=0)$ to the maximum depth of interest $(z=-L)$, by the following equation

$$
\int_{0}^{-L} \frac{\partial \theta}{\partial t} d z=\left.\left.K \frac{\partial H}{\partial z}\right|_{z=-L^{-}} K \frac{\partial H}{\partial z}\right|_{z=0}
$$

Because there is no flow across the plastic-covered soil surface, the second term on the right-hand side of Equation (2.6) effectively becomes zero. Substituting $(h+z)$ for $\mathrm{H}$ and rearranging Equation (2.6) yields

$$
K(\theta)=\frac{\int_{0}^{-L} \frac{\partial \theta}{\partial t} d z}{\frac{\partial h}{\partial z}+1}
$$

The values on the right-hand side of Equation (2.7) are evaluated to determine $K(\theta)$ at selected times for each depth of measurement.

Using a time-averaging approach, the integral, $1 \partial \theta / \partial \mathrm{t} d z$, of Equation (2.7) can be estimated by trapezoidal approximation for each depth interval, as described by Green, Ahuja, and Chong (1986). The water content from the surface $(z=0)$ to the first depth of measurement is taken as that measured at the first depth. For example, for data points at 30 -cm-depth intervals and at depth, $z_{1}$,

$$
\int_{0}^{z 1} \partial \theta / \partial t d z=30 \theta_{1}+\sum_{i=1}^{n-1} 30\left(\theta_{i}+\theta_{j+1}\right) / 2
$$

where $\theta_{i}$ is the soil-water content measured at the $i^{\text {th }}$ point in the profile, measured from the top of the profile, and $n$ is the number of data points down to depth, $z_{1}$. The total head gradients are then approximated by 


\section{$\partial H / \partial z=\left[h\left(\operatorname{depth}_{z+1}, t\right)-h\left(\operatorname{depth}_{z}, t\right) /\left(\operatorname{depth}_{z+1}-\operatorname{depth}_{z}\right)\right]-1$}

where all variables have been defined previously. Alternatively, head gradients can be determined by curve-fitting techniques as outlined by Green, Ahuja, and Chong (1986). Fluxes are calculated at each depth and measurement time to be equal to the volume change in water stored between measurement depths during a given time interval, as determined from the previously described trapezoidal integration procedure. Time-averaged gradients and water contents are then calculated, and hydraulic conductivity values corresponding to the time-averaged water content are determined by dividing the calculated fluxes by the time-averaged gradients.

Using an instantaneous profile approach, volumetric water content is plotted versus time for each depth of measurement, and curves are fit to these data. The slopes of these curves $(-\partial \theta / \partial t)$ are then measured at selected times and multiplied by their respective depth increments to obtain the per-layer rate of water content change. The flux through the bottom of each layer is then calculated by accumulating the water content increments of all layers overlying that depth $[i$.e., $q=(\partial \theta / \partial t) / d z]$. Matric head values are plotted versus time, and the depth of each tensiometer is added to each matric head value to obtain total hydraulic head profiles. Then, the hydraulic conductivity is calculated by dividing the flux values by their corresponding hydraul ic head gradient values.

The time-averaging and instantaneous profile procedures should yield similar results, especially with data from soil profiles that are relatively uniform by depth. Differences between the results obtained by the two procedures are caused by the different approximations of the differential and integral quantities.

Black, Gardner, and Thurtell (1969) studied drainage losses from lysimeters and noted that the "unit gradient" condition was often valid. Davidson et al. (1969) rewrote Equation (2.5) in unit gradient form such that

$$
\frac{\partial \theta}{\partial t}=\frac{\partial}{\partial z}[-K(\theta)]
$$


Using Equation (2.7) to estimate hydraul ic conductivities requires knowledge of the rate of change in water content and the hydraulic head gradient. The unit gradient method modifies this data requirement by assuming that the head gradient is uniformly equal to 1 . This condition arises when the water content is nearly uniform with depth, and results in $\partial \mathrm{h} / \partial \mathrm{\partial z} \approx 0$ and $\partial \mathrm{H} / \partial \mathrm{\partial z} \approx 1$.

Sisson, Ferguson, and van Genuchten (1980) solved Equation (2.10) by using a solution scheme proposed by Lax (1972). This solution can be used in two ways. First, if soil hydraulic properties are known, the solution describes the water content profile between the soil surface and the advancing drainage front. Second, if water content is measured during drainage, the solution can be used to estimate soil hydraulic properties. Both applications are limited by the validity of the unit gradient assumption.

Sisson (1987) extended the concept of a unit gradient to a "fixed gradient", where $\partial H / \partial z$ may not be identical to 1 , but is a function of depth, and is invariant with time. Scaling theory is incorporated into the assumption of a fixed gradient to define new water content and space variables. The fixed gradient thereby becomes a unit gradient, when written in terms of the scaled variables. This extension al lows the fixed-gradient problem to be solved using unit gradient solutions.

The fixed gradient analyses used in this study assume a power function relationship between hydraulic conductivity and water content. This relationship is the Watson (1967) model

$$
K=K_{f s}\left(\theta / \theta_{\mathbb{m}}\right)^{1 / \beta}
$$

where $K_{f s}$ is the field-saturated hydraulic conductivity, $\theta_{m}$ is the maximum water content obtained during ponding, and $\boldsymbol{\beta}$ is an unknown parameter. When the ponding phase of an unsteady drainage-flux method experiment has ended, the final rate of infiltration is used to estimate $K_{f s}$, and $\theta_{\mathrm{m}}$ is approximated by averaging the water contents at each depth to the deepest depth of interest. Multiple regression is then performed on $\log (z / t)$ versus $\log \theta$ to determine the slopes and intercepts of least-squares fits of straight lines to the data. The depth, $\mathrm{z}$, is measured from the soil surface, and the time, 
$\mathbf{t}$, is the time at which neutron probe measurements are taken after ponded water disappears from the surface of the plot. These slopes and intercepts are then used to scale the data and to determine the $\boldsymbol{\beta}$ parameter in the Watson (1967) model.

\subsection{GUELPH PERMEAMEIER}

The Guelph permeameter method (Reynolds and Elrick 1985) measures the steady-state rate of water intake from a cylindrical auger hole in which a constant depth of water is maintained. The air-inlet tube of the Guelph permeameter is used to establish and maintain a constant head level, H, while the corresponding discharge rate, $Q$, is measured as the rate of discharge from the permeameter water reservoir. This method simultaneously measures in situ field-saturated hydraulic conductivity, $K_{f s}$, and matric flux potential, $\phi_{m}$, in the unsaturated zone. The Guelph permeameter used in this study was obtained from Soil Moisture Equipment Corp., P.O. Box 30025, Santa Barbara, CA 93105.

The matric flux potential is defined by Gardner (1958) as

$$
\phi_{m}=\int_{h}^{0} K(h) d h ;-\infty \leq h \leq 0
$$

where $K(h)$ is the hydraulic conductivity-matric head relationship. Calculations using the Guelph permeameter method assume the exponential $\mathrm{K}(\mathrm{h})$ relationship of Gardner (1958)

$$
\mathrm{K}=\mathrm{K}_{\mathrm{fs}} \exp (\mathrm{ah}) ; \mathrm{h}_{\mathrm{i}} \leq \mathrm{h} \leq \mathbf{0}
$$

where a is the slope of the curve $\ln (K)$ versus $h$, and $h_{j}$ is the initial matric head in the soil. Substituting Equation (2.13) into (2.12) and integrating produces

$$
\phi_{m}=\frac{K_{f s}}{a}\left[1-\exp \left(a h_{i}\right)\right]
$$


which simplifies to

$$
a=K_{f s} / \phi_{m}
$$

for many soils at "field capacity" or drier conditions (Scotter, Clothier, and Harper 1982). Field capacity is not a quantitatively defined water content. However, it can be qualitatively defined as the water content of a relatively uniform, deep soil that has drained for 2 to $\mathbf{3}$ days after thorough wetting. This is generally considered to be a water content reached under conditions of no evaporation or water uptake by plants.

Steady-state recharge depends on $\mathbf{K}_{\mathbf{f s}}$ and $\phi_{\mathbf{m}}$. The steady-state recharge rate, $Q$, is given by

$$
Q=\frac{2 \pi H^{2}}{C} K_{f s}+\pi a^{2} K_{f s}+\frac{2 \pi H}{C} \phi_{m}
$$

where the first, second, and third terms on the right-hand side of the equation represent the pressure, gravity, and capillarity components, respectively. Equation (2.16) is an approximate analytical solution based on saturated-unsaturated flow theory (Reynolds and Elrick 1985), where $\mathrm{H}$ is the head level in the well, a is the well radius, and $\mathrm{C}$ is the shape of the saturated soil "bulb" surrounding the well hole. The value of $\mathrm{C}$ is primarily a function of $\mathrm{H} / \mathrm{a}$ in saturated soils, but also depends on soil structure, texture, and initial matric head in unsaturated soils. Values of $\mathrm{C}$ were obtained from standard C-curves in the operating instructions for the Guelph permeameter. These standard curves were developed from numerical simulations of steady, saturated-unsaturated flow around wells in coarse sand, Guel ph loam, and unstructured clay.

The field-saturated hydraulic conductivity and matric flux potential in this study were calculated from steady-state recharge rates by a simultaneous equation approach, referred to as the Richards analysis (GP-R) by Reynolds, Elrick, and Clothier (1985) using Equation (2.16). The GP-R analysis requires two or more constant head level discharge measurements. Therefore, 
when steady-state flow is reached at one head level, the air-inlet tube is simply raised to a different height, and the steady-state recharge at that head level is measured.

\subsection{PREDICTIVE TECHNIQUES}

The RETC.F77 computer program (van Genuchten 1985) was used to fit a mathematical function to the measured and predicted water retention data, and to predict unsaturated hydraulic conductivities. This program uses nonlinear, least-squares curve fitting to fit a soil WRC of the form

$$
\theta=\theta_{r}+\left(\theta_{s}-\theta_{r}\right)\left[\frac{1}{1+(\alpha h)^{n}}\right]^{m}
$$

where $\theta_{r}=$ residual soil water content

$\boldsymbol{\theta}_{\mathbf{S}}=$ saturated soil water content

$\mathrm{h}=$ matric head

$a, m$, and $n=$ curve-fitting parameters.

Mualem (1976) developed a general model to predict the hydraul ic conductivity from the soil WRC. This model has the form

$$
K=K_{s} s_{e}^{l}\left[f\left(s_{e}\right) / f(1)\right]^{2}
$$

where

$$
f\left(S_{e}\right)=\int_{0}^{S_{e}} \frac{1}{h\left(S^{\prime}\right)} d S_{e}^{\prime}
$$

$$
S_{e}=\left(\theta-\theta_{r}\right) /\left(\theta_{s}-\theta_{r}\right) \text {, and } 2 \text { is a parameter. }
$$

Assuming that $m=1 \cdot 1 / n$, van Genuchten (1978) derived a closed-form solution to Equation (2.17). This solution is

$$
k_{r}\left(S_{e}\right)=s_{e}^{1 / 2}\left[1-\left(1-s_{e}^{1 / m}\right) m\right]^{2}
$$


or in terms of matric head

$$
K(h)=\frac{\left\{1-(a h)^{n-1}\left[1+(a h)^{n}\right]-m\right\}^{2}}{\left\{[1+(a h)]^{n}\right\}^{m / 2}}
$$

where $\mathbf{K}_{\mathbf{r}}$ (or relative hydraulic conductivity) is the hydraulic conductivity divided by the saturated hydraulic conductivity.

One method for predicting the WRC is the physicoempirical model by Arya and Paris (1981). This is essentially a capillary pore model that first translates the particle-size distribution into a pore-size distribution. Cumulative pore volumes, corresponding to increasing pore radii, are divided by the sample bulk volume to give volumetric water content. The pore radii are converted to equivalent matric head values by using the equation of capillarity

$$
h_{i}=2 \gamma \operatorname{cosa} / \rho_{w} g r_{i}
$$

where $\mathbf{h}_{\mathbf{j}}=$ soil matric head corresponding to the $i^{\text {th }}$ pore increment

7 = surface tension of water

$\mathrm{a}=$ contact angle of water with soil particles

$\rho_{\mathrm{W}}=$ density of water

$g$ = gravitational acceleration

$r_{i}=$ radius of the $i^{\text {th }}$ pore.

In this study, the surface tension was taken as that of pure water at $25^{\circ} \mathrm{C}$ $(71.97$ dynes $/ \mathrm{cm})$, and the contact angle was assumed to be zero.

To compute the pore volumes and radii, the particle-size distribution is divided into segments. The solid mass in each segment is assumed to form a matrix with a bulk density equal to that of a natural structure sample. For a unit of sample mass, an equivalent pore volume is computed from

$$
v_{i}=\left(w_{i} / \rho_{p}\right) e_{i} i=1,2, \ldots, n
$$


and the corresponding pore radius from

$$
r_{i}=R_{i}\left[4 e n_{i}^{(1-a)} / 6\right]^{1 / 2}
$$

where $v_{v_{j}}=$ pore volume

$$
\begin{aligned}
\boldsymbol{W}_{\mathbf{i}} & =\text { solid mass } \\
\rho_{\mathbf{p}} & =\text { particle density } \\
e & =\text { void ratio } \\
\mathbf{r}_{\mathbf{i}} & =\text { mean pore radius } \\
\mathbf{R}_{\mathbf{i}} & =\text { mean particle radius } \\
\mathbf{n}_{\mathbf{i}} & =\text { number of particles } \\
\mathbf{a} & =\text { an empirical constant } .
\end{aligned}
$$

The formulation for the pore radius assumes spherical particles and cylindrical pores.

During the auguring of some of the well holes used for the Guelph permeameter measurements, known volumes of soi 1 were removed from each auger hole at the depth at which permeameter measurements were taken. These samples were sealed in plastic bags to maintain original water content and then oven dried in the laboratory for soil bulk density measurements. A brass cylinder sampler was also used to collect bulk density samples from the Grass site and McGee Ranch unsteady drainage-flux experiment plots.

Bulk density samples were also used for determining particle-size distribution by a sieve analysis and hydrometer method (Gee and Bauder 1986). These particle-size distribution and bulk density data were then used to predict water retention characteristics by using the model of Arya and Paris (1981). Predicted water retention characteristics were then fit with the RETC.F77 computer program, and hydraulic conductivities were calculated with the program using Mualem's (1976) hydraulic conductivity model. In general, this and other models work best when the predicted hydraulic conductivity values are scaled to one or more measured values. The most common approach is to scale the predicted values using the measured saturated hydraulic conductivity as a matching point between curves. 


\subsection{SITE DESCRIPTIONS}

Three locations at the Hanford Site were selected for unsaturated hydraulic conductivity measurements: the BWIF, Grass, and McGee Ranch sites. The locations of these sites are shown in Figure 1.1. These sites represent three distinct soil profiles as shown in Figure 3.1.

The BWIF and Grass sites are research sites from which data are being collected for validation studies of the UNSAT-H unsaturated flow code (Fayer, Gee, and Jones 1986). Soil from the McGee Ranch site is currently being tested as the surface cover for the Hanford Site Protective Barriers (Kirkham and Gee 1987). The influence of texture, bulk density, and layering on the hydraulic properties of soils from these three locations is of interest for barrier system design and development, as well as for model validation.

\subsection{BURIED WASTE TEST FACILITY}

The BWTF is located adjacent to the 300 North Area burial grounds (see Figure 1.1). The facility consists 'of an array of seven corrugated,

BWTF

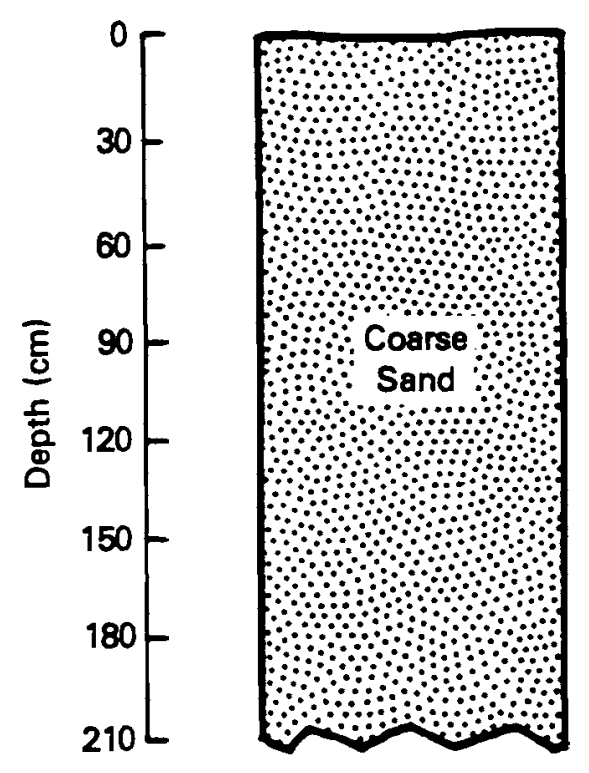

FIGURE 3.1. Soil Profiles at the Field Sites
Grass Site
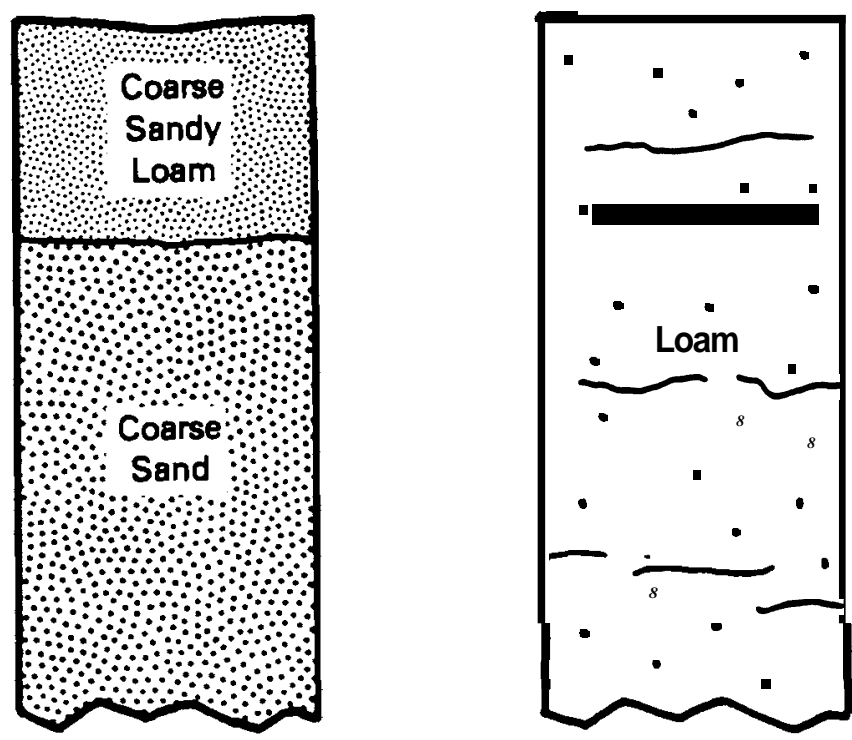
galvanized-steel caissons of two different diameters, bolted together in the arrangement shown in Figure 3.2, and two weighing lysimeters (not shown). All seven caissons are $7.6 \mathrm{~m}$ long. The three large caissons are 2.7-m dia. and the four small caissons are $0.6-\mathrm{m}$ dia. These caissons are filled with a relatively uniform material, consisting of approximately $97 \%$ sand, $2 \%$ silt, and $1 \%$ clay (L-soi 1). This soil consists of the same material that was excavated for the facility, but with particles greater than 1.27-cm dia. screened out. This facility was originally designed for field water balance and radionuclide transport studies. Construction and originhl instrumentation specifications are described by Phillips et al. (1979).

Samples of L-soil were collected in 1978 during the construction of the BWTF. During the summer of 1986 , laboratory measurements of hydraulic conductivity were made on these samples using the steady-state flux control method, described in Section 2.1.

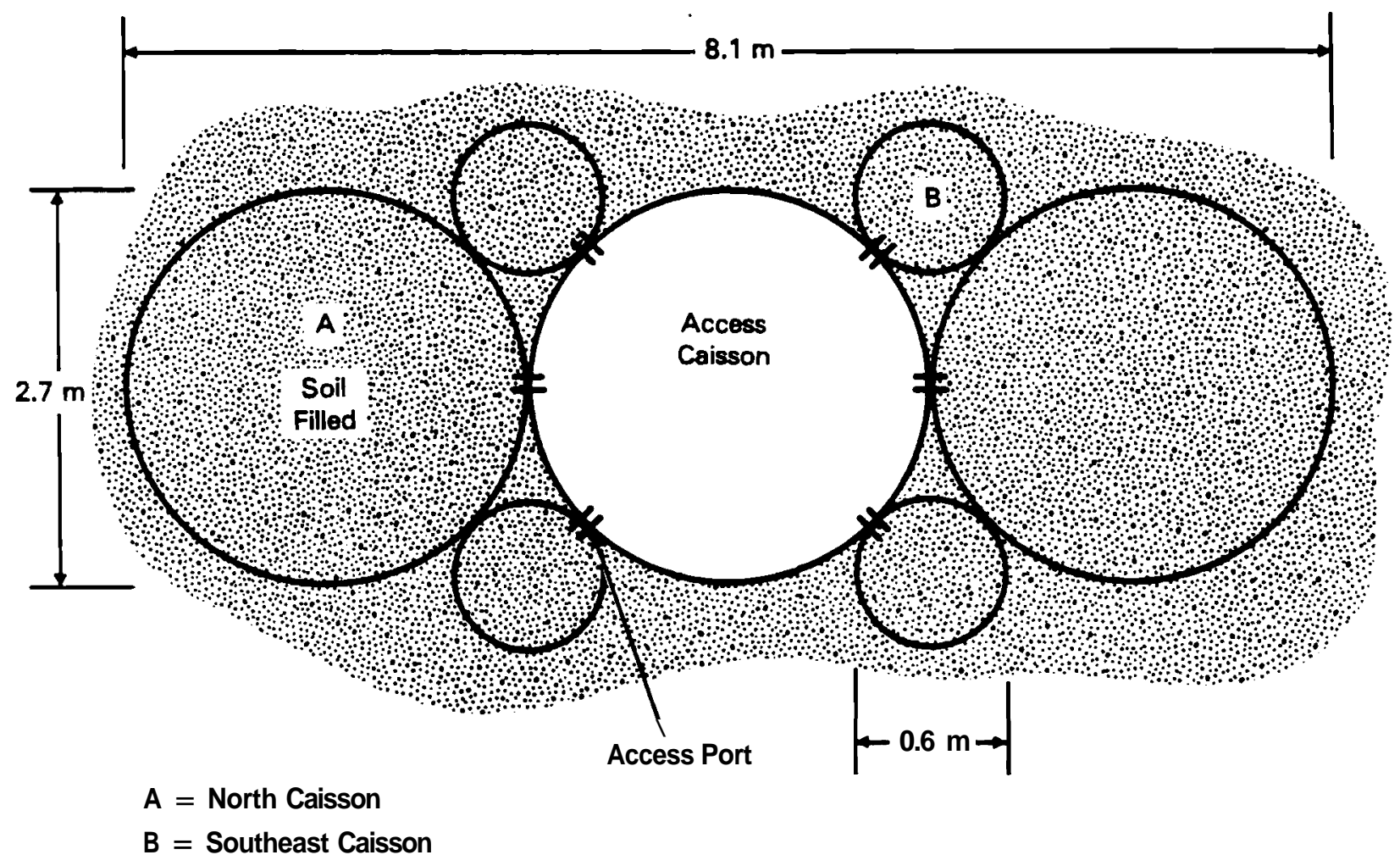

FIGURE 3.2. Layout of the Buried Waste Test Facility Caissons 
Two unsteady drainage-flux method studies were conducted at the BWTF in October 1986. These studies were in the large north caisson and the small southeast caisson (A and B, respectively, in Figure 3.2). The upper 20 and $10 \mathrm{~m}$ of fill material were removed from caissons $A$ and $B$, respectively, to expose the tops of the caissons. These exposed ends of the caissons acted as enclosures for ponding water during infiltration. In the southeast caisson, an additional $60 \mathrm{~m}$ of soil was excavated to remove a previously emplaced plastic liner. The removed soi 1 was packed back into the caisson after removing the liner.

Guelph permeameter measurements were taken in the area around the caissons in September and October 1986, and within the north caisson in July 1987.

\subsection{GRASS SITE}

The Grass site is located approximately $3 \mathrm{~km}$ southwest of the BWTF. It is situated in a broad, shallow topographic depression approximately $900 \mathrm{~m}$ wide and several hundred meters long in a northeast-southwest direction. Ongoing water balance and transpiration studies are being conducted at this location (Gee and Kirkham 1984).

The soil at the Grass site is $3.5 \mathrm{~m}$ thick and is well drained. The upper-most $0.6 \mathrm{~m}$ of the soil profile contains approximately $74 \%$ sand, $21 \%$ silt, and 5\%clay, and is classified as a sandy loam to loamy sand [borderline, but previously classified as a loamy sand by Gee and Kirkham (1984)]. From 0.6 to $3.5 \mathrm{~m}$, the soil consists of approximately $91 \%$ sand, $6 \% \mathrm{silt}$, and 3\%clay, and is classified as a sand. A gravel layer that lies below the $3.5-\mathrm{m}$ depth is estimated to be several meters thick, based on excavations at adjacent sites.

This site is instrumented with 25 neutron-probe access tubes arrayed in a 5 by 5 grid with a $6-\mathrm{m}$ spacing between tubes. The unsteady drainage-flux experiment conducted at this site in July 1987 was a repeat of a previous study (Gee and Kirkham 1984), using the same plot ( $2 \mathrm{~m}$ by $2 \mathrm{~m}$ ) and neutronprobe access tube (No. 25). The 1984 study was repeated in an attempt to 
investigate a wider range of water content and to measure hydraulic head that was not measured successfully in the first study.

Guelph permeameter measurements were made at depths of 20- and 60-cm for various locations around the grid of neutron-probe access tubes in September and October 1986. Additional measurements were made in July and August 1987, both around and within the unsteady drainage-fl ux experiment plot.

\subsection{MCGEE RANCH}

The MoGee Ranch is approximately $37 \mathrm{~km}$ northwest of the BWTF. This site has been characterized for near-surface soil texture and other physical properties (Last et al. 1987). The soil texture at this site ranges from silt loam to sandy loam. The average particle-size distribution of soil samples collected from the MoGee Ranch during this study is 36\% sand, 49\% silt, and $15 \%$ clay, which classifies the soil as a loam. The ground surface at the MoGee Ranch slopes 3\% to 5\% to the south.

An unsteady drainage-flux experiment was conducted at this site in July 1987. The location of the $2 \mathrm{~m}$ by $2 \mathrm{~m}$ study plot was between the north-south MoGee Ranch road and a borrow pit from which fine soils were taken for the Field Lysimeter Test Faci lity. Several thin $(<1-\mathrm{cm})$ caliche layers were encountered during installation of tensiometers at depths of approximately 35,80 , and $100 \mathrm{~cm}$.

Guelph permeameter measurements were taken in July and August 1987, at various locations around the borrow pit at the MoGee Ranch and within the unsteady drainage-flux experiment plot at this site. 


\subsection{RESULTS AND DISCUSSION}

The following sections describe the results of the methods used at each site. Collected data are reported in tabular and graphic form in the following sections, and in tabular form in the appendixes.

\subsection{BURIED WASTE TEST FACILITY}

Laboratory measurements of unsaturated hydraulic conductivity were made on L-soil collected from the BWTF using the steady-state flux control method. Two unsteady drainage-flux method experiments were conducted in the southeast and north caissons (see Figure 3.2). Guelph permeameter measurements were made in the area immediately surrounding the BWTF site and within the north caisson. Soil samples were collected from the permeameter auger holes and were used for particle-size analysis and subsequent water retention characteristic predictions using the Arya and Paris (1981) model. Predicted water retention curves (WRCs) were then used to predict hydraulic conductivities with the RETC.F77 computer program, using Mualem's (1976) predictive conductivity model.

\subsubsection{Steady-State Flux Control Method}

Hydraul ic conductivity data from two replications and two bulk densities for L-soil are displayed on Figure 4.1. The actual 8, $h$, and $k$ values are listed in Appendix A, Table A.1. The bulk density variation had little discernible effect on the measured hydraulic conductivity values. Each replicated test required one week to pack and saturate the samples and approximately six weeks to collect six to seven data points. Obtaining data points for the lower water contents (achieved with a low flux rate) took the majority of the six-week period, because the time necessary to achieve steady-state flow was longer (because of the low flux rates).

\subsubsection{Unsteady Drainaage-Flux Method}

Water content data for the southeast caisson drainage study are plotted on Figure 4.2 and 1isted in Appendix A, Table A.2. Because there was no collection of matric head data during this experiment, we assumed that a unit gradient condition existed. Hydraulic conductivities were then calculated 


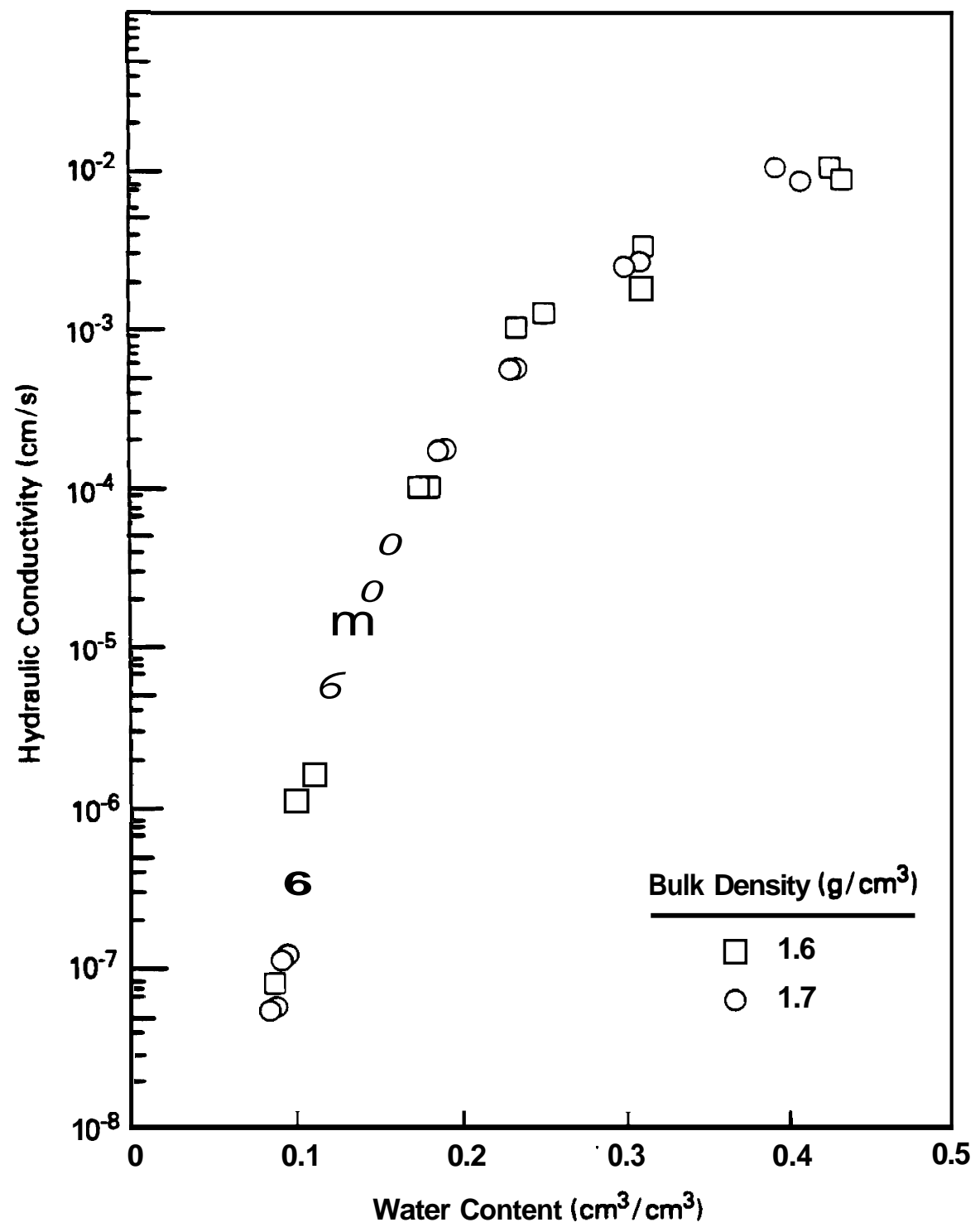

FIGURE 4.1 Measurements of Unsaturated Hydraulic Conductivity of L-Soil by the Steady-State Flux Control Method

using the instantaneous profile method (Watson 1966) and the Lax solution method (Si sson, Ferguson, and van Genuchten 1980).

Hydraulic conductivities determined using the instantaneous profile method are plotted on Figure 4.3 and are listed in Appendix A, Table A.3. The hydraulic conductivity data for soil depths below $90 \mathrm{~cm}$ are grouped relatively close together. The hydraulic conductivity data for the three depths above $90 \mathrm{~cm}$, however, show more variance with respect to water content. We 


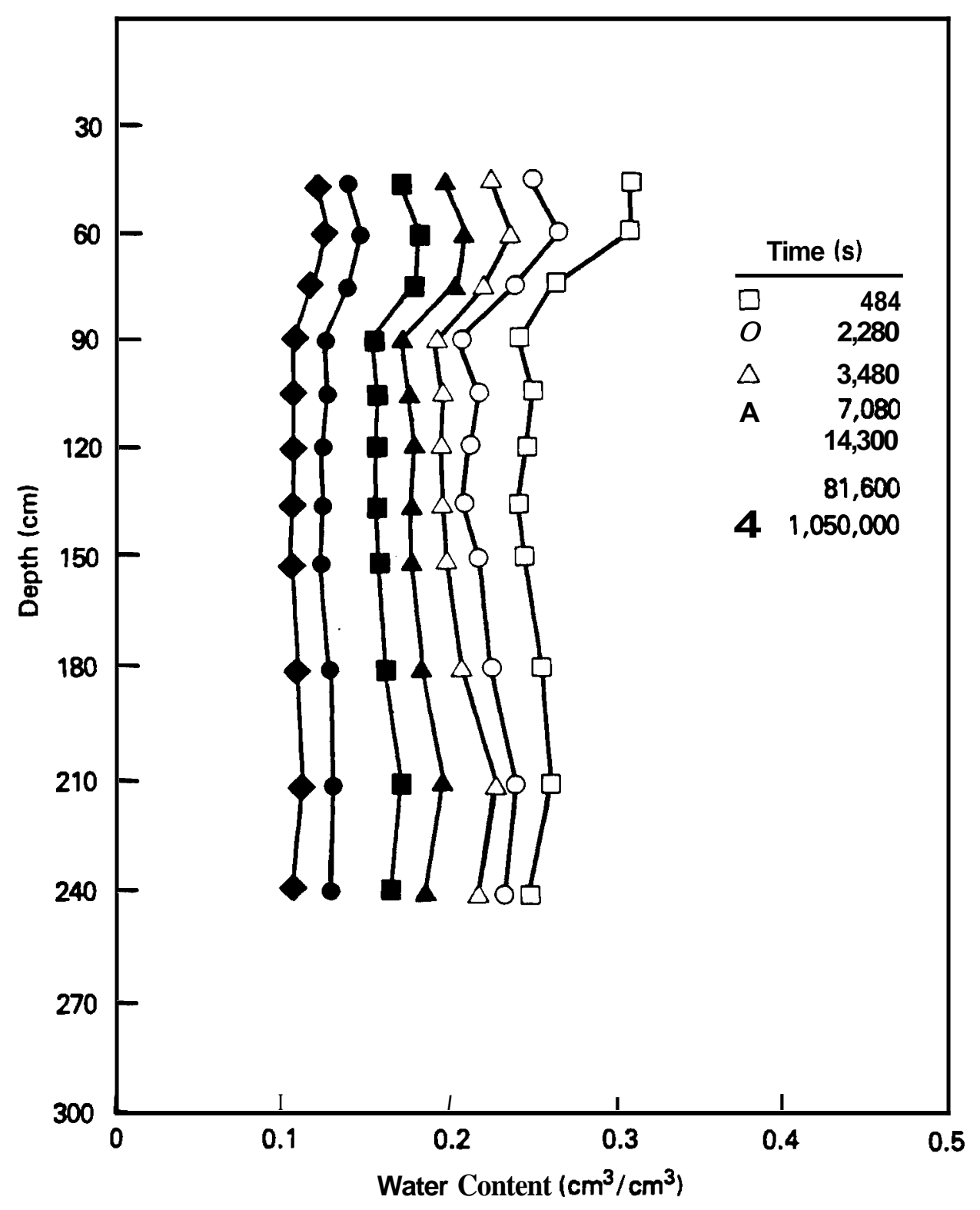

FIGURE 4.2. Water Content Profiles Observed During the Unsteady Drainage-Flux Experiment in the Southeast Caisson

believe this difference resulted from the upper $60 \mathrm{~m}$ of soil being disturbed (to remove a previously emplaced plastic liner) and repacked just prior to beginning the experiment. The effect of this disturbance was to create a zone with a lower bulk density than at the lower depths (i.e., a layering effect). 


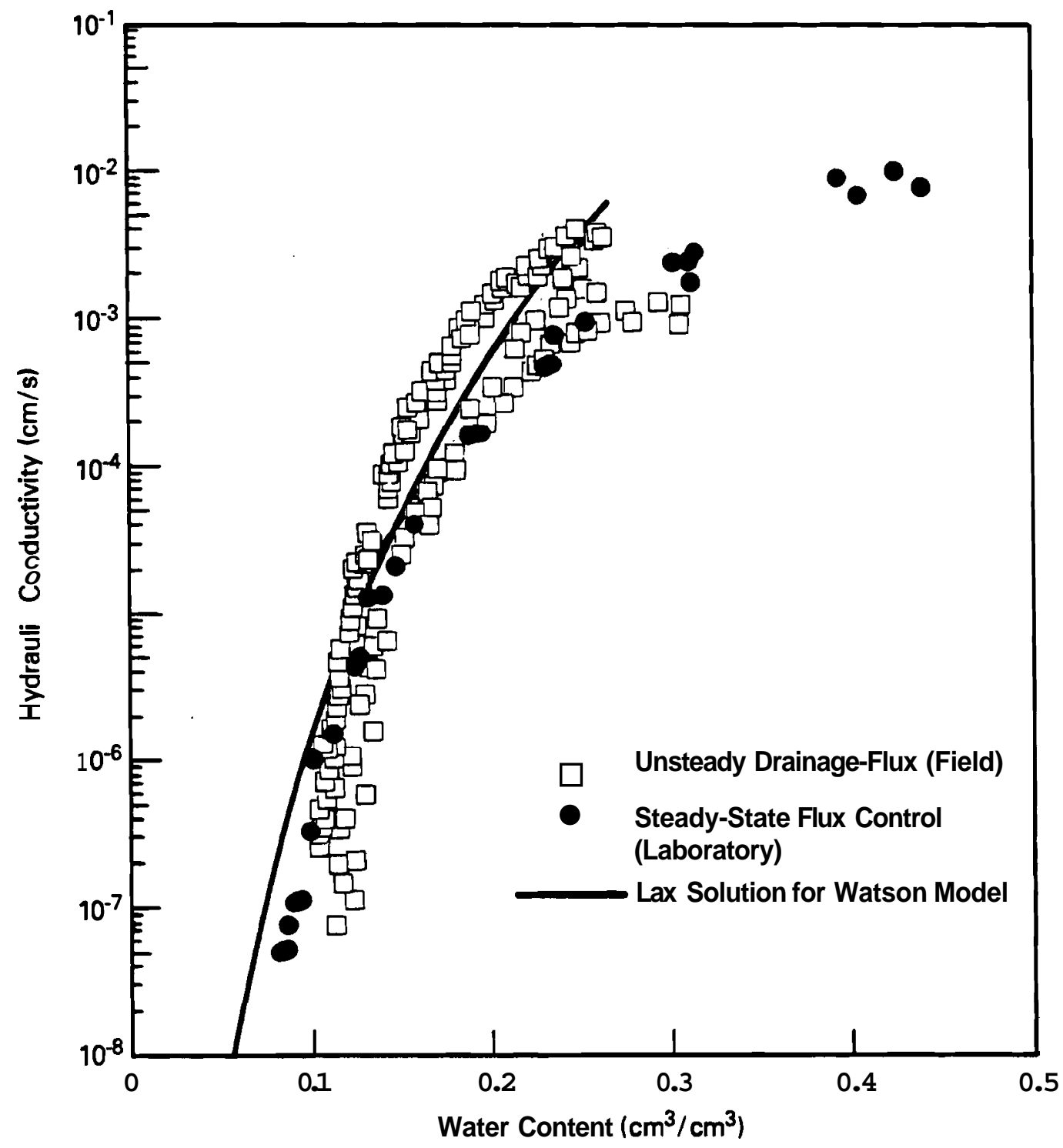

FGURE 4.3. Hydraulic Conductivity as a Function of Water Content from the Unsteady Drainage-Flux Experiment in the Southeast Caisson, from Repacked Columns in the Laboratory, and from the Lax Solution (Sisson, Ferguson, van Genuchten 1980) for the Watson (1967) $K(\theta)$ Relationship

Also plotted on Figure 4.3 are the laboratory data from Figure 4.1. The field data from the upper three depths in the caisson agree with the laboratory data fairly we11, suggesting similar bulk density and packing characteristics between the L-soil in the laboratory and the upper three depths in the caisson. Between water contents of approximately 0.12 and $0.25 \mathrm{~cm}^{3} / \mathrm{cm}^{3}$, hydraulic conductivities from the lower depths are higher than 
the laboratory values by as much as a factor of five. For water contents between 0.10 and $0.12 \mathrm{~cm} 3 / \mathrm{cm}^{3}$, the field-measured conductivities match the laboratory conductivities more closely.

There are several possible explanations for the differences between the laboratory and the field conductivities. As mentioned previously, the variation in packing density expected for field conditions (compared to the relative uniformity of packing within a laboratory column) could have contributed to the differences. Figure 4.1, however, indicates that a bulk density variation of $0.1 \mathrm{~g} / \mathrm{cm}^{3}$ had no discernible effect on the laboratorymeasured conductivity values. Another explanation is that the neutron probe was not adequately calibrated for the caissons. The neutron probe that was used is undergoing recalibration, but a preliminary analysis of the new calibration curve indicates that water contents will not change by much more than $0.01 \mathrm{~cm}^{3} / \mathrm{cm}^{3}$, and that calculated conductivities will not change by more than about 5\%. A third possibility is that, early in the experiment, a significant amount of entrapped air may have been present (the caisson side ports were sealed and the bottom was partially sealed). The entrapped air would have affected the hydraulic head gradients. Unfortunately, we have no measure of hydraulic head gradients during the experiment and have relied on the assumption of a unit gradient.

Complete saturation of a soil profile is very difficult, if not impossible, to obtain in a field experiment. All pores are not interconnected or open, and air may become trapped in some of the open pore spaces, effectively preventing water from filling them. If an unlimited water supply were available, and water could be ponded on the plot or the plot irrigated for an extended period of time, much of the entrapped air would dissolve. Unfortunately, such conditions are not possible for most field studies of this type. Therefore, curves fit to field-measured water retention data from most unsteady drainage-flux method experiments do not represent true desorption curves, but are actually intermediate scanning curves representing the effects of hysteresis (the nonuniqueness of the water content-matric head relationship). In a typical laboratory setup, columns of soil are saturated from the bottom, or under a vacuum, so that air is driven out the top of the 
col umn as the soi 1 becomes saturated. Therefore, 1aboratory WRCs generally represent true desorption curves. These differences are part of the reason why laboratory and field-measured retention and hydraulic conductivity data typically are not in complete agreement.

The second method for analyzing the southeast caisson data is based on the Lax solution (Sisson, Ferguson, and van Genuchten 1980). Multiple regression of $\log (z / t)$, which equals $\log (d k / d \theta)$, versus $\log 8$ by the method of dumy variables, was performed to determine the slopes and intercepts of these lines for parameter estimation in the Watson (1967) model. The depth, $z(\mathrm{~cm})$, is measured from the soil surface, and the time, $t$ (days), is measured from when water first disappeared from the soil surface (i.e., time zero).

The lines shown on Figure 4.4 are least-squares fits to data from each depth. Eleven regression lines are portrayed on this figure (one for each depth), but some of them fall on top of each other. Although the sand in the caisson is relatively uniform with respect to particle-size distribution, the regression lines representing data from the upper three depths are separated from the other regression lines. It is apparent that the disturbed soil was packed to a lower bulk density than the rest of the caisson soil, and that the hydraulic properties of the upper $70 \mathrm{~m}$ were thus altered, as indicated by the separation between regression lines. This same conclusion was reached after reviewing the instantaneous profile calculations and is consistent with data from layered soil profiles (Sisson 1987).

In Figure 4.5, the water content from each depth was adjusted by the amount, $\left(\theta / \theta_{\mathrm{m}}\right) \times 10^{\mathrm{B}_{\mathrm{k}} / \mathrm{B}_{\mathrm{o}}}$, and replotted as a single curve with the average intercept of the curves shown on Figure 4.4. The $\theta_{\mathrm{m}}$ value is the maximum water content reached at each depth. The regression coefficients, $B_{k}$ and $B_{0}$, are the intercepts and slopes, respectively, of least-squares fits of straight lines to data from each depth. Adjusting or scaling the data as shown on Figure 4.5 shows that a large portion of the variance observed in measured $K(\theta)$ values can be removed by adjusting or scaling specific water contents by a fixed amount that depends on spatial position [see Sisson (1987) for fixed gradient model details]. Scaling of the water content data in this way also enables outliers in the data set to be readily identified. 


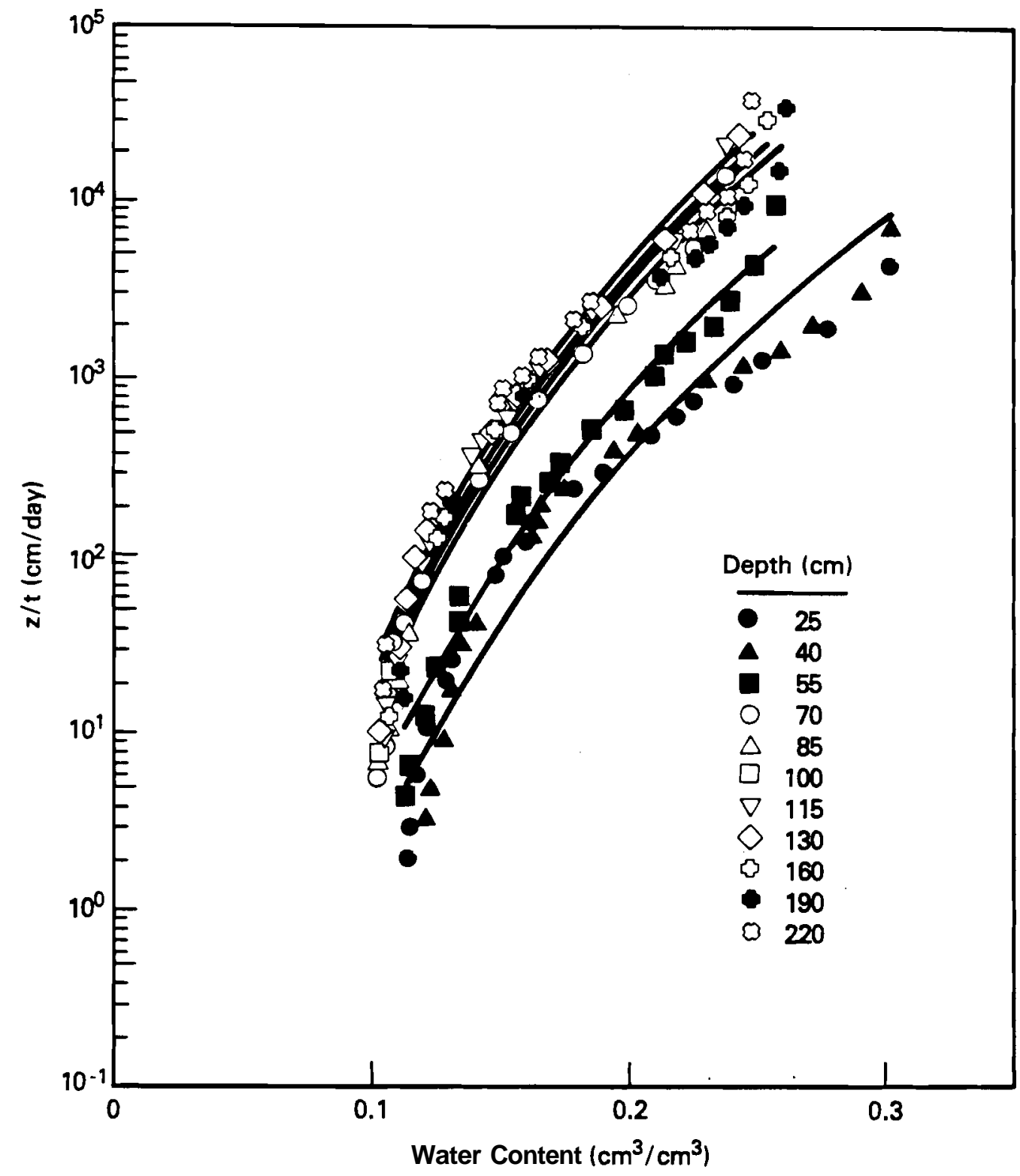

FIGURE 4.4. Depth (z)/Time (t) Versus Water Content from the Unsteady Drainage-Flux Experiment in the Southeast Caisson. Curves represent Lax solution (Sisson, Ferguson, van Genuchten 1980) to Watson (1967) $K(\theta)$ relationship, with individual curves fitted to data from each depth.

The infiltration rate at the end of the 2-h ponding period was $0.0063 \mathrm{~cm} / \mathrm{s}$. This value was used as an estimate of $\mathrm{K} \mathrm{fs}$. The volumetric water content of all depths was averaged to obtain an estimate of $\boldsymbol{\theta}_{\mathbf{s}}=0.262$ $\mathrm{cm}^{3} / \mathrm{cm}^{3}$. Substituting these $\boldsymbol{\theta}_{\mathbf{s}}$ and $K_{f s}$ values into the Watson (1967) equation resulted in the following $K(\theta)$ relationship: 


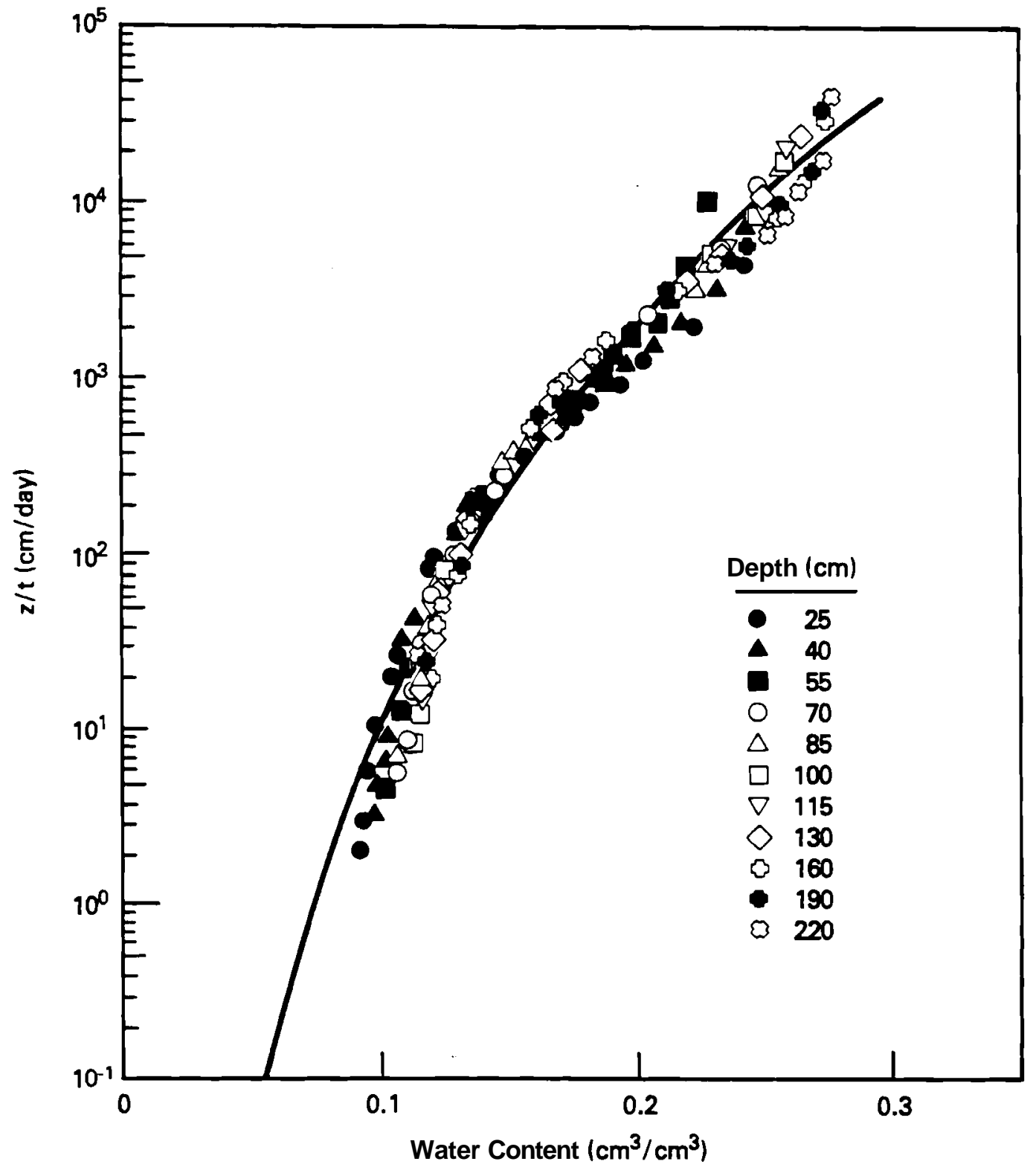

FIGURE 4.5. Depth ( $\mathbf{z}) /$ Time (t) Versus Scaled Water Content from the Unsteady Drainage-Flux Experiment in the Southeast Caisson. Curve shown'has the same slope and the average intercept of the curves shown in Figure 4.4.

$$
K(\theta)=0.0063(\theta / 0.262)^{8.59}
$$

where 8.59 is the slope of the $\log (z / t)$ versus $\log \theta$ regression line, plus 1 , after scaling the data. Taking the derivative of the Watson (1967) equation results in the following equation: 


$$
\mathrm{dK} / \mathrm{d} \theta=\mathrm{K}_{\mathrm{fs}} / \beta \theta_{\mathrm{m}}\left(\theta / \theta_{\mathrm{m}}\right)^{1 / \beta-1}
$$

where $1 / \beta-1$ is the slope of the regression line. Therefore, 1 must be added to the slope before substituting back into the original equation for $1 / \beta$. The solid line shown on Figure 4.3 shows the $K(\theta)$ relationship (Watson 1967) determined from this analysis.

The unsteady drainage-flux method was also used to determine hydraulic conductivities in the north caisson at the BWTF site. Water content profiles for several times during the north caisson drainage study are plotted on Figure 4.6 and listed in Appendix A, Table A.4. The maximum water content during ponding was approximately $0.30 \mathrm{~cm}^{3} / \mathrm{cm}^{3}$ for all depths, or $75 \%$ saturation for a total porosity calculated to be 0.397 assuming bulk and particle densities of 1.7 and $2.82 \mathrm{~g} / \mathrm{cm}^{3}$, respectively. These densities were determined from laboratory analysis of L-soil. This maximum value of water content is approximately $25 \%$ higher than the maximum value for the southeast caisson data for depths below $60 \mathrm{~cm}$. The fact that both experiments resulted in a water content significantly less than the total porosity suggests that entrapped air was present. The presence of entrapped air would prevent the attainment of complete saturation (Klute 1986). The difference in maximum water content between the two caissons may reflect the fact that not all of the north caisson surface was ponded. The electric pump that supplied water for ponding on the surface of the caissons did not have a high enough flow rate to pond water over the entire surface of the north caisson. Therefore, water was only ponded on a wedge-shaped section of the north caisson, representing approximately one-third of its total area. By not ponding water over the entire caisson surface, air could escape more easily from the north caisson than from the southeast caisson. If this were true, this mechanism may be partly responsible for the higher average water content $\left(0.305 \mathrm{~cm}^{3} / \mathrm{cm}^{3}\right)$ in the north caisson, than in the southeast caisson $\left(0.262 \mathrm{~cm}^{3} / \mathrm{cm}^{3}\right)$.

Another observation based on Figure 4.6 is the rapidity with which the profile drained. More than half of all the water that eventually drained, drained during the first hour. From this observation, we conclude that 


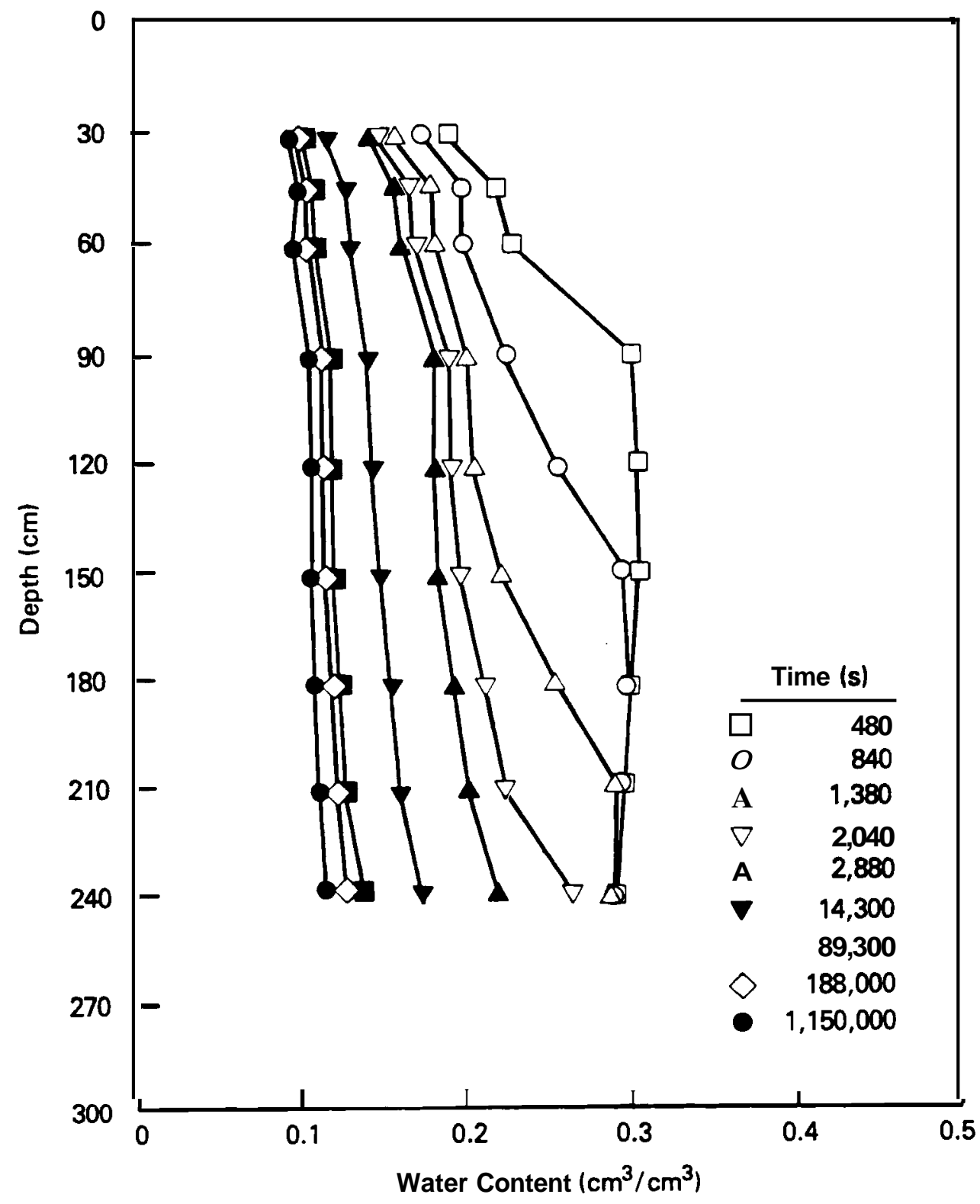

FIGURE 4.6. Water Content Profiles Observed During the Unsteady DrainageFlux Experiment in the North Caisson

during the early drainage phase, many measurements are needed to clearly delineate the shape of the $d \theta / d t$ curve. Also, the rapid rate of drainage creates a problem, in that a finite amount of time is needed to obtain a water content measurement at each depth, and the total time necessary to scan all depths is significant. To simplify calculations, the recorded time of measurement was taken as the time at the beginning of the first reading. In 
retrospect, especially for the early drainage times, it may have been more appropriate to correct for the intervals of time needed to lower the neutron probe and to obtain readings at each depth.

The matric head data in Appendix A, Table A.5 were used to calculate hydraulic head values for the BWTF north caisson experiment. These head values were used to construct the head profiles shown on Figure 4.7. Although the head profiles indicate unit gradient conditions throughout most of the drainage phase of the experiment, there are times when the gradient near the surface is less than unity. Therefore, hydraulic conductivity calculations using the north caisson data were made with the actual gradient measurements (i.e., a unit gradient was not assumed). Hydraul ic conductivities were calculated by the instantaneous profile method for each measurement time and are listed in Appendix A, Table A.6.

Figure 4.8 contains a plot of hydraulic conductivity versus water content for all depths of the BWTF north caisson, and a plot of the laboratory data from Figure 4.1. The results are similar to the results from the southeast caisson with respect to their general relationship to water content. In fact, the data indicate that the north caisson, like the southeast caisson, has hydraulic conductivities that are higher than the laboratory data at water contents exceeding $0.12 \mathrm{~cm}^{3} / \mathrm{cm}^{3}$. Higher conductivities at lower water content in the caissons suggest that flow through macropores may have had a much greater effect on water content changes in the caissons than in the laboratory columns at water contents exceeding $0.12 \mathrm{~cm}^{3} / \mathrm{cm}^{3}$. If this were true, it is probably the result of differences in packing density between the caissons and the laboratory columns.

Analysis of the north caisson data by the Lax solution method (Sisson, Ferguson, and van Genuchten 1980) and fixed gradient analysis (Sisson 1987) resulted in the following $\mathrm{K}(8)$ relationship for the Watson (1967) model:

$$
K(\theta)=0.025(\theta / 0.305)^{8.08}
$$

The value of $0.025 \mathrm{~cm} / \mathrm{s}$ represents the infiltration rate at the end of the $1.5-\mathrm{h}$ ponding period. The water content value of $0.305 \mathrm{~cm} 3 / \mathrm{cm}^{3}$ is the average of the water content values for all depths at the end of the 


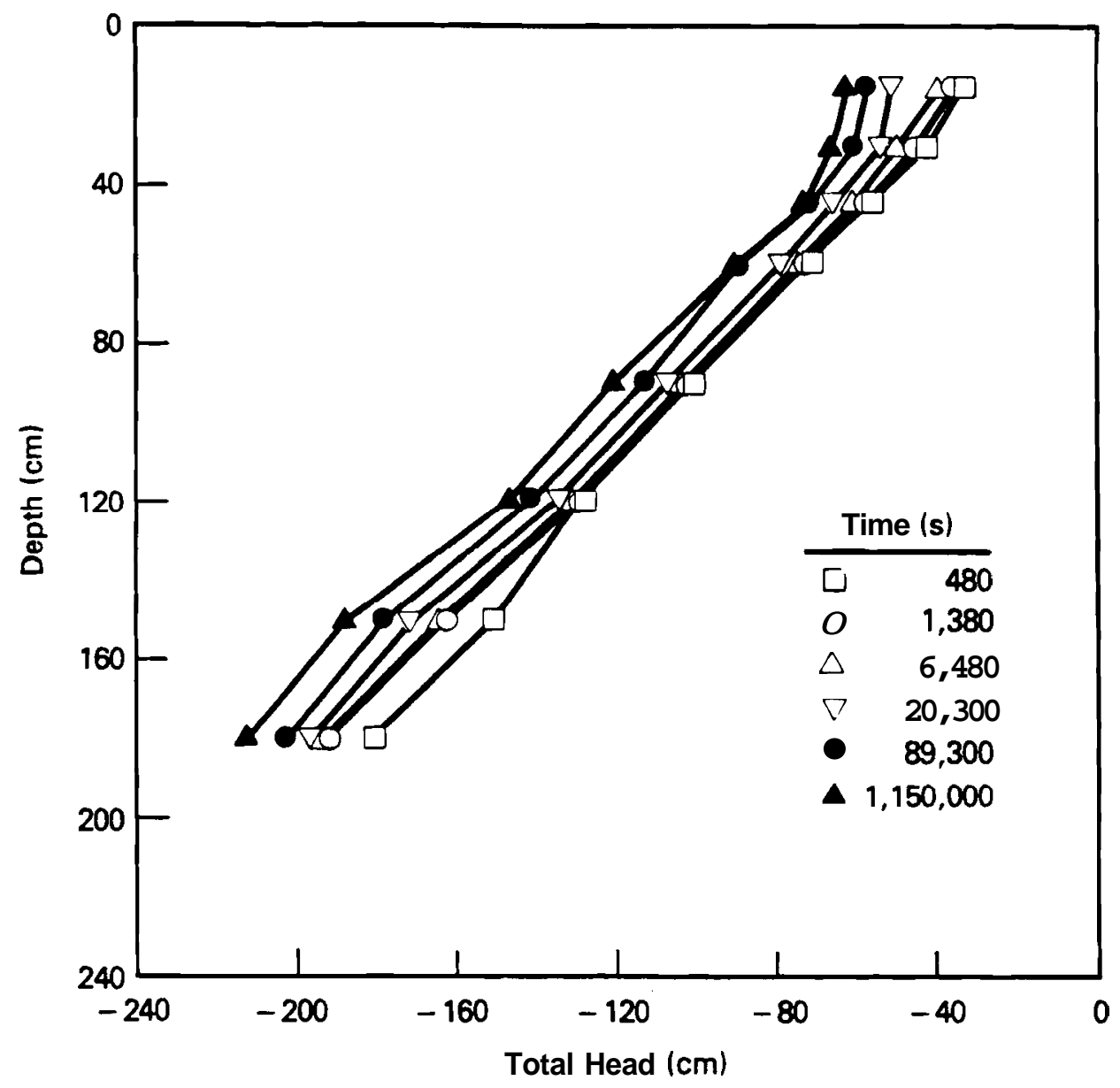

FIGURE 4.7. Hydraulic Head Profiles Observed During the Unsteady Drainage-Flux Experiment in the North Caisson

infiltration and start of drainage. The slope of the $\log (z / t) \cdot$ versus $\log \theta$ regression line was 7.08. Scaling the data had very little effect on regression parameters because of the uniformity of the profile. The solid line on Figure 4.8 resulted from substituting values of $\theta$ into Equation (4.3) and plotting the resulting $K(\theta)$ values.

The $K_{f s}$ of $0.025 \mathrm{~cm} / \mathrm{s}$ from the north caisson is four times larger than the $\mathrm{Kfs}$ of $0.0063 \mathrm{~cm} / \mathrm{s}$ at the southeast caisson. The potential for threedimensional flow resulting from not ponding water over the entire surface of the caisson could explain the higher $\mathrm{K}_{\mathrm{fs}}$ value obtained in the north caisson. Once the profile is wetted and ponding has ceased however, flow is essentially vertical in both caissons. The higher $\mathrm{K}_{\mathrm{fs}}$ in the north caisson could also be a result of the higher degree of saturation. 


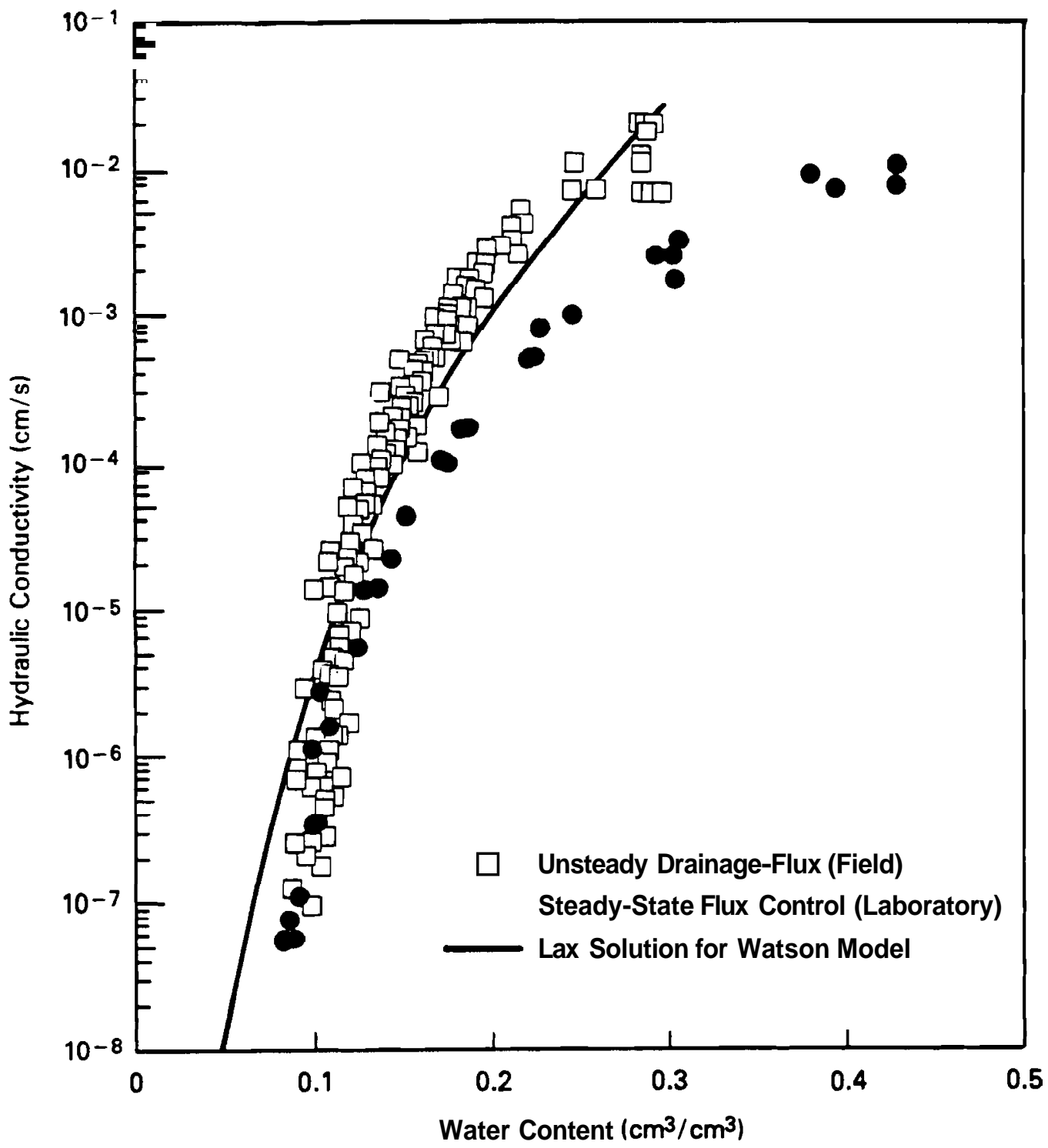

FIGURE 4.8. Hydraulic Conductivity as a Function of Water Content from the Unsteady Drainage-Fl ux Experiment in the North Caisson, from Repacked Columns in the Laboratory, and from the Lax Solution for the Watson $K(\theta)$ Relationship

The rate of infiltration of the ponded water after approximately $2 \mathrm{~h}$ of ponding may not be truly representative of the field-saturated hydraulic conductivity. The infiltration rate was not measured as a function of time; consequently, the actual steady-state infiltration rate normally ascribed to $\mathrm{K}_{\mathrm{fs}}$ may not have been reached. Better estimates of the $\mathrm{K}_{\mathrm{fs}}$ value used in the Watson (1967) model could probably be obtained by the Guelph permeameter or other methods. 
The Watson (1967) model curves show higher hydraulic conductivities than are indicated by laboratory data and lower conductivities than are indicated by most of the field data for the southeast and north caissons at water contents between 0.10 and $0.30 \mathrm{~cm}^{3} / \mathrm{cm}^{3}$. At lower water contents, the curves show higher conductivities than are indicated by measured data. Overall, this Watson (1967) model $\mathbf{K}(\theta)$ relationship provides a fairly good description of the measured data from the BWTF site.

\subsubsection{Guelph Permeameter Method}

The Guelph permeameter method measures $K_{f s}$ rather than the actual saturated conductivity, $\mathbf{K}_{\mathbf{s}}$. Field-saturated hydraulic conductivities are generally lower than actual saturated conductivities, because the presence of entrapped air reduces the pore space available for flow as previously described. Studies by Stephens et al. (1983) and Stephens, Lambert, and Watson (1984) suggest that reasonably accurate estimates of $\mathbf{K}_{\mathbf{s}}$ can usually be obtained by simply doubling the $\mathrm{K}_{\mathrm{fs}}$ measurement obtained from the Guelph permeameter method. The arithmetic mean value of $\mathrm{K}_{\mathrm{fs}}$ for 15 sets of measurements by the Guelph permeameter at the BWTF site is $0.0045 \mathrm{~cm} / \mathrm{s}$. The arithmetic mean of the four laboratory measurements of $\mathbf{K}_{\mathbf{s}}$ (Appendix A, Table A.1) is $0.0084 \mathrm{~cm} / \mathrm{s}$. Hence, for the BWTF soil, the Stephens et al. (1983) and Stephens, Lambert, and Watson (1984) approximations appear to be val id.

Table 4.1 shows the results of the Guelph permeameter analyses from 15 sets of measurements taken around the BWTF site and within the north caisson at the BWTF site. Plotted on Figure 4.9 is the exponential $\mathbf{K}(\mathrm{h})$ relationship determined from the average of these 15 measurements. This relationship is

$$
K=0.0045 \exp [0.0573 \mathrm{~h})]
$$

where 0.0045 is the field-saturated hydraul ic conductivity $(\mathrm{cm} / \mathrm{s}), 0.0573$ is the slope of the lognormal $\mathrm{K}$ versus $\mathrm{h}$ line, and $\mathrm{h}$ is the matric head. Included on Figure 4.9 are the laboratory and field measurements of unsaturated hydraul ic conductivity (see Appendix A). Examination of Figure 4.9 raises the question of whether or not the exponential $\mathrm{K}(\mathrm{h})$ relationship assumed in the Guelph permeameter analysis adequately describes the $\mathbf{K}(\boldsymbol{h})$ 
TABLE 4.1. Results from the Guelph Permeameter for the Buried Buried Waste Test Facility

$\begin{array}{cccc}\frac{K_{f s}, \mathrm{~cm} / \mathrm{s}}{\text { Location }} & & \phi_{\mathrm{m}, \mathrm{cm}} 2 / \mathrm{s} & \alpha \\ \begin{array}{c}\text { Outside Caissons, } \\ \text { 30-cm depth }\end{array} & & & \\ 1 & 0.0006 & 0.0063 & 0.0952 \\ 2 & 0.0010 & 0.0860 & 0.0116 \\ 3 & 0.0051 & 0.0367 & 0.1390 \\ 4 & 0.0031 & 0.0297 & 0.1044 \\ 5 & 0.0058 & 0.0925 & 0.0627 \\ 7 & 0.0026 & 0.1140 & 0.0228 \\ 8 & 0.0029 & 0.0122 & 0.2377 \\ 13 & 0.0005 & 0.0326 & 0.0153 \\ 14 & \underline{0.0002} & \underline{0.0727} & \underline{0.0028} \\ \text { Average } & 0.0024 & 0.0536 & 0.0448\end{array}$

Within North Caisson

$\begin{array}{cccc}15 \mathrm{~A} & 0.0051 & 0.2286 & 0.0223 \\ 17 \mathrm{~B} & 0.0008 & 0.1340 & 0.0060 \\ 18 \mathrm{~A} & 0.0159 & 0.0547 & 0.2907 \\ 18 \mathrm{~B} & 0.0065 & 0.0785 & 0.0828 \\ 19 \mathrm{~A} & 0.0108 & 0.1119 & 0.0965 \\ 19 \mathrm{~B} & \underline{0.0069} & \underline{0.0892} & \underline{0.0774} \\ \text { Average } & 0.0077 & 0.1162 & 0.0663 \\ \text { Overall Average } & 0.0045 & 0.0786 & 0.0573\end{array}$

$A=30-\mathrm{cm}$ depth.

$B=60-\mathrm{cm}$ depth.

relationship of this soil. This exponential relationship matches the laboratory data within approximately 1 order of magnitude over the range of matric heads shown. The field data show more of a straight-1ine $K(h)$ relationship than the laboratory data, but the slope of the line constructed from the Guelph permeameter data does not match the trend of the field data from the unsteady drainage-flux method experiment.

\subsubsection{Predictions}

Figure 4.10 shows field-measured water retention data from the unsteady drainage-flux experiment in the north caisson. The solid line was fit to the data by the RETC.F77 computer program with the Mualem-based (1976) restriction, $m=1-1 / n$. Also shown on Figure 4.10 are RETC.F77 curve fits to water 


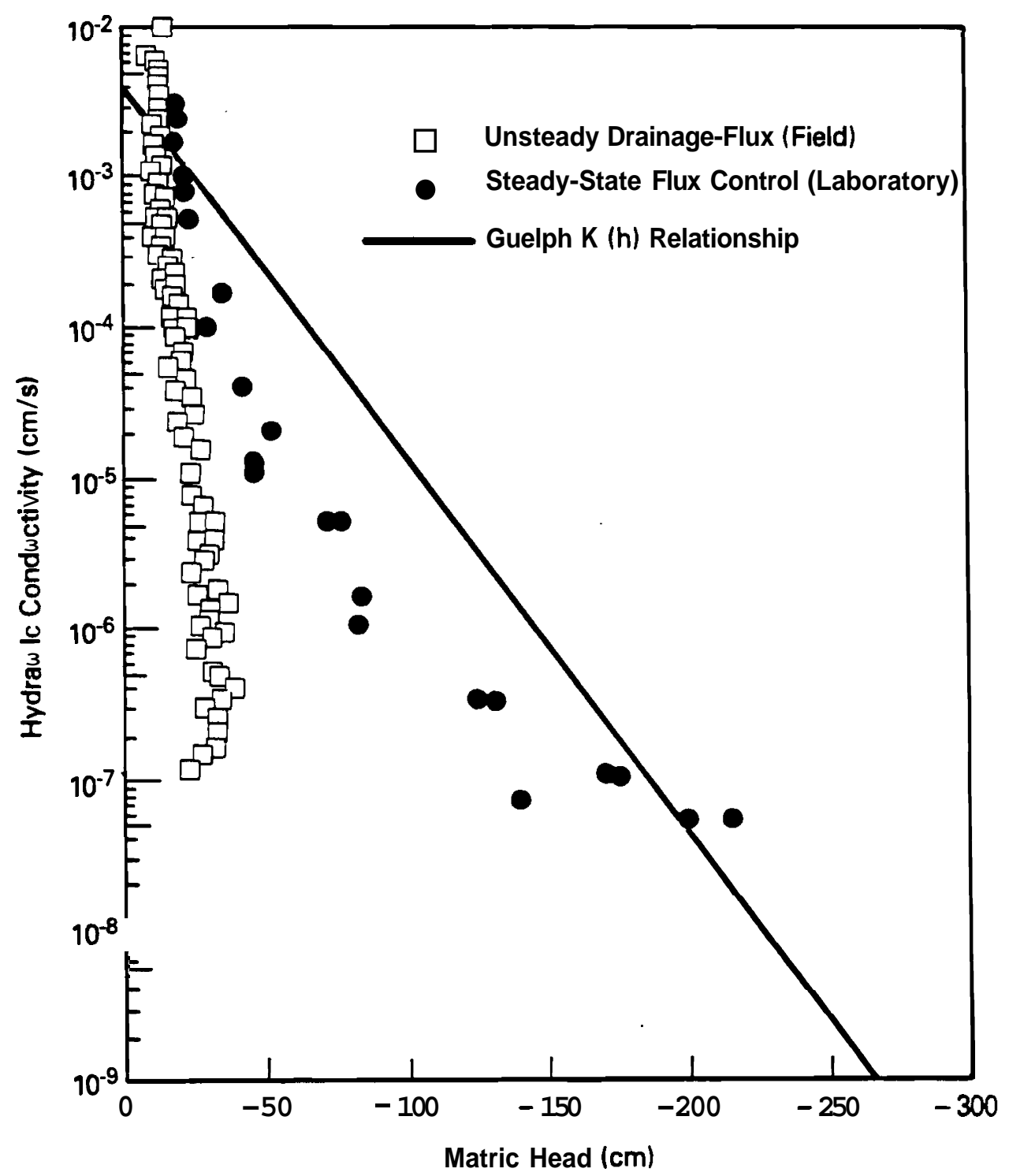

FIGURE 4.9. Hydraulic Conductivity as a Function of Matric Head from the Unsteady Drainage-Fl ux Experiment in the North Caisson, from Repacked Columns in the Laboratory, and the $K(h)$ Relationship Determined from the Average of 15 Sets of Guelph Permeameter Measurements at the Buried Waste Test Facility

retention values predicted by the Arya and Paris (1981) model. These water retention predictions are based on a composite particle-size distribution of samples BWTF-18A and $-18 \mathrm{~B}$ collected within the north caisson at depths of 30 and $60 \mathrm{~cm}$, respectively. A bulk density of $1.7 \mathrm{~g} / \mathrm{cm}^{3}$ and a particle density of $2.82 \mathrm{~g} / \mathrm{cm}^{3}$ were used in the model to calculate a saturated volumetric water content of $0.397 \mathrm{~cm}^{3} / \mathrm{cm}^{3}$. The dashed line is a curve fitted to 


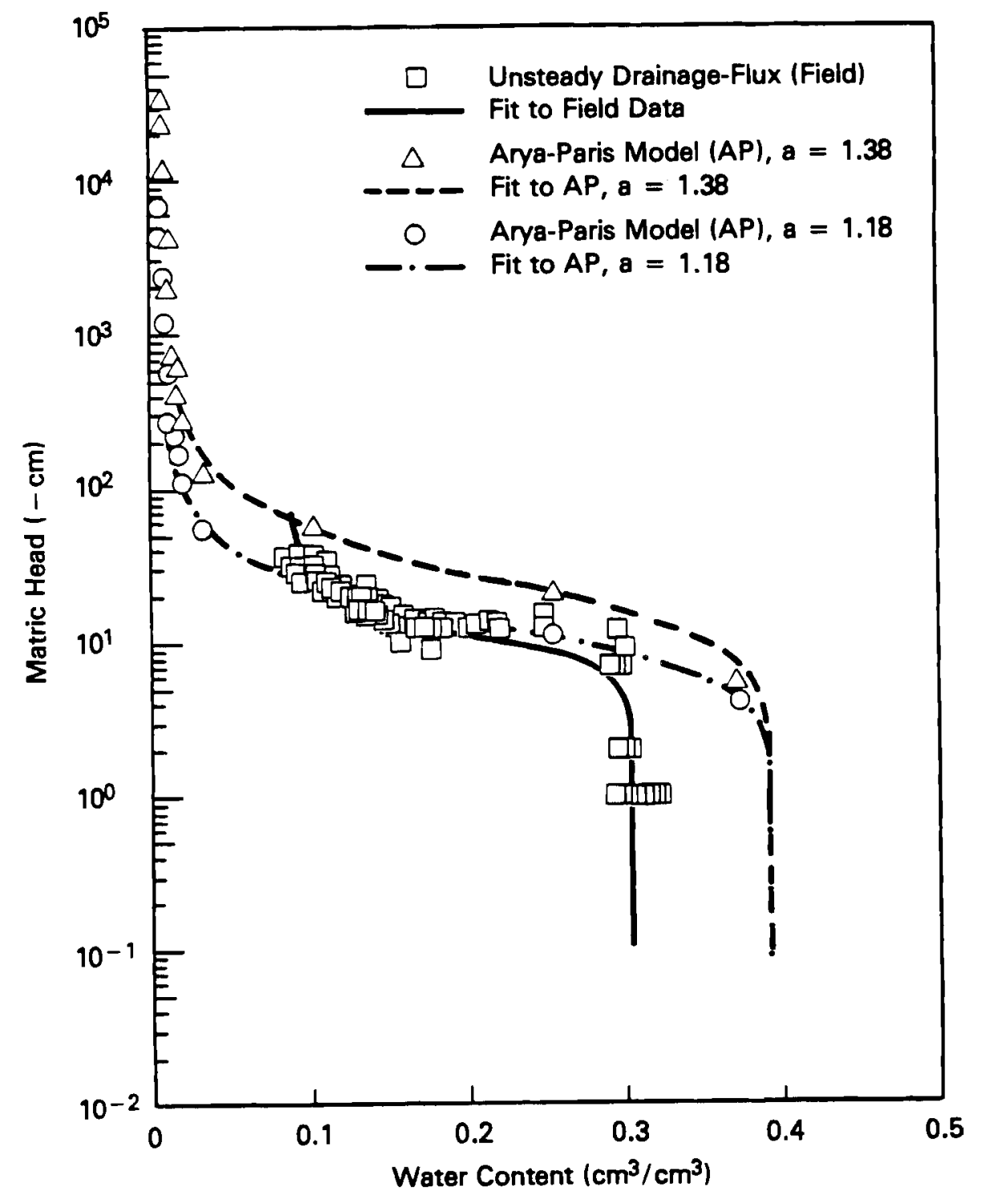

BOURE 4.10. Water Retention Curves Fit to Data from the Unsteady Drainage-Flux Experiment in the North Caisson and to Water Retention Characteristics Predicted by the Arya-Paris (AP) (1981) Model. Predicted values were generated from a composite particle-size distribution of Samples $18 \mathrm{~A}$ and $18 \mathrm{~B}$ with the AP model "a" $=1.38$ and 1.18

water retention predictions with the "a" term in the Arya and Paris (1981) model set at 1.38. This value was the best-fit value of the "a" parameter determined by Arya and Paris (1981) for the range of soils in their study. 
The dashed-dotted line is a curve fitted to water retention predictions with the "a" term set at 1.18. This value of "a" was determined by visual fit to the measured data.

Hydraul ic conductivities calculated by the instantaneous profile method for the north caisson data are shown on Figure 4.11. Also shown on Figure 4.11 is the hydraulic conductivity curve based on field-measured water

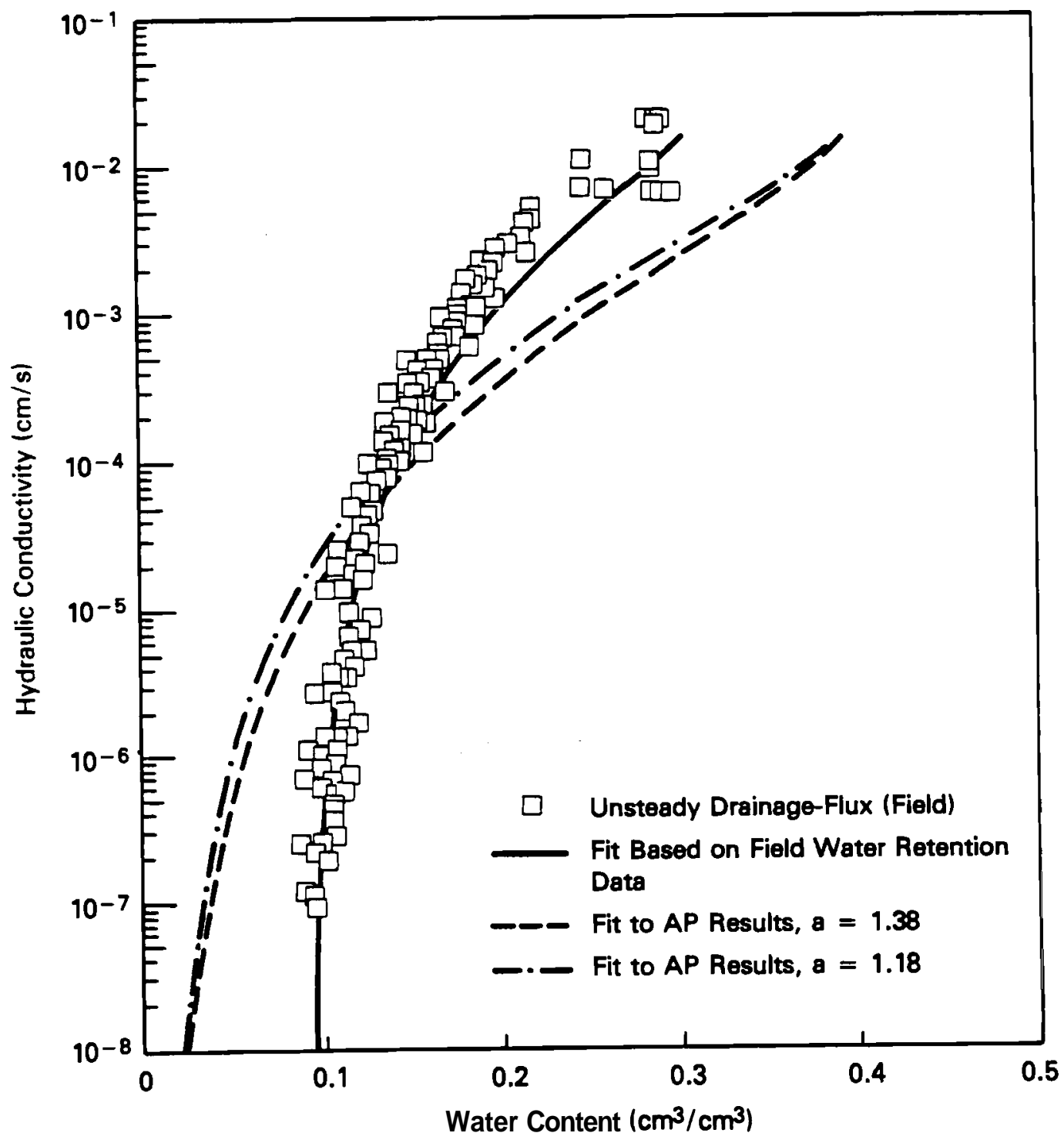

FIGURE 4.11. Hydraulic Conductivity as a Function of Water Content from the Unsteady Drainage-Flux Experiment in the North Caisson and Predicted Curves Based on the AryaParis (AP) (1981) Model Results Shown in Figure 4.10 
retention data with the $K_{\mathbf{s}}$ value fixed at $0.0154 \mathrm{~cm} / \mathrm{s}$ and the $\theta_{\mathbf{S}}$ value internally fitted by the program at $0.309 \mathrm{~cm} 3 / \mathrm{cm}^{3}$. This $K_{\mathbf{s}}$ value is two times the arithmetic mean of nine Guelph $\mathrm{K}_{\mathrm{fs}}$ measurements within the north caisson (see Appendix B, Table B.1). The " $\ell$ " parameter used in the Mualem (1976) model was fixed at 0.5, which was the best-fit value of the parameter determined by Mualem (1976) in an analysis of several soils. The restrictions of $m=1-1 / n$ and $\ell=0.5$ were imposed on all of the curves fit to measured data. The fit to the measured hydraulic conductivity data can be improved by allowing the RETC.F77 program to fit values for $\mathrm{m}$ and $\ell$ and/or by simultaneously fitting water retention and hydraulic conductivity data. As shown on Figure 4.11, the measured data could apparently be fit better by fixing $\boldsymbol{K}_{\mathbf{s}}$ at a higher value or by allowing the program to fit a $\mathbf{K}_{\mathbf{s}}$ value.

The dashed line on Figure 4.11 represents hydraulic conductivities calculated from the water retention values predicted by the Arya and Paris (1981) model, with $\mathrm{a}=1.38$ and $\mathrm{K}_{\mathrm{fs}}$ and $\theta_{\mathrm{S}}$ fixed at $0.0154 \mathrm{~cm} / \mathrm{s}$ and 0.397 $\mathrm{cm}^{3} / \mathrm{cm}^{3}$, respectively. The calculated $\theta_{\mathrm{s}}$ value of 0.397 was fixed to correspond with the $\mathbf{K}_{\mathbf{s}}$ value of $0.0154 \mathrm{~cm} / \mathrm{s}$ in the curve-fitting process. The dashed-dotted line represents hydraul ic conductivities calculated by the same method with $\mathrm{a}=1.18$. Predicted and measured conductivities differ from one another by an order of magnitude or less at water contents exceeding 0.10 $\mathrm{cm}^{3} / \mathrm{cm}^{3}$. At lower water contents, however, differences between measured and predicted values are much greater.

Changing the "a" term in the Arya and Paris (1981) model from 1.38 to 1.18 lowered the predicted matric head values by a factor of 2 to 6 between water contents of 0.40 and $0.025 \mathrm{~cm}^{3} / \mathrm{cm}^{3}$. Differences between predicted matric head values at lower and higher water contents were relatively small and almost negligible at saturation and at water contents less than approximately $0.025 \mathrm{~cm}^{3} / \mathrm{cm}^{3}$. Changing the "a" parameter had very little effect on the predicted hydraulic conductivities shown on Figure 4.11. The general shapes of the water retention and hydraulic conductivity curves in Figure 4.11 are very similar.

The hydraulic conductivities based on the Arya and Paris (1981) model water retention predictions agree more closely with the laboratory data than the field data from the north caisson (see Figure 4.8). The calculations of 
pore volumes associated with each soil-particle grain-size fraction in the Arya and Paris model assume that particles in each size fraction are packed in a discrete domain and that, when all domains are considered, the resulting assemblage has a bulk density equal to that measured for a natural-structure sample. The model also assumes that the total pore space calculated from the particle and bulk densities is available for filling and is filled at saturation. Therefore, predicted hydraulic conductivities are likely to agree more closely with the laboratory data than with the field data. This is a result of the uniform packing of the laboratory columns to the bulk density used for predicting water retention values and the thorough saturation of the laboratory col umns. The RETC. F77 computer program curve-fitting results are shown in Table 4.2. See Section 2.2 for parameter descriptions.

\subsection{GRASS SITE}

An unsteady drainage-flux experiment was conducted at the Grass site. Guelph permeameter measurements were made around the neutron probe access well grid at the site, and within the unsteady drainage-flux experiment plot.

TABLE 4.2. Curve-Fitting Results from the RETC.F77 Computer Program Based on Data from the Buried Waste Test Facility

\begin{tabular}{|c|c|c|c|c|c|c|c|}
\hline \multirow[b]{2}{*}{ Data Set } & \multicolumn{7}{|c|}{ Parameters (a) } \\
\hline & $\theta_{r}$ & $\theta_{s}$ & $\underline{a-}$ & m & $\mathrm{n}$ & 1 & $\mathrm{~K}_{\mathrm{S}}$ \\
\hline $\begin{array}{l}\text { BWTF-North Caisson } \\
\text { Water Retention } \\
\text { Data }\end{array}$ & 0.09 & 0.307 & 0.0931 & $\mathrm{R}$ & 3.6956 & $0.5^{\star}$ & $0.0154^{*}$ \\
\hline $\begin{array}{l}\text { AP-Predicted Water } \\
\text { Retention from } \\
\text { Samples 18A and } \\
18 \mathrm{~B}(\mathrm{a}=1.38)\end{array}$ & 0.0095 & $0.397^{\star}$ & 0.0531 & $\mathrm{R}$ & 2.2719 & $0.5^{\star}$ & $0.0154^{\star}$ \\
\hline $\begin{array}{l}\text { AP-Predicted Water } \\
\text { Retention from } \\
\text { Samples } 18 \mathrm{~A} \text { and } \\
18 \mathrm{~B}(\mathrm{a}=1.18)\end{array}$ & 0.0106 & $0.397^{*}$ & 0.0972 & $\mathrm{R}$ & 2.5554 & $0.5^{\star}$ & $0.0154^{*}$ \\
\hline
\end{tabular}

(a) See Section 2.2 for Parameter definitions. $\mathrm{AP}=$ Arya and Paris (1981) model

$\underset{*}{R}=$ Mualem (1976) based restriction, $m=1-1 / n$ = Value was fixed 
Soi 1 samples, collected from the auger holes used for permeameter measurements, were used for particle-size analysis.

\subsubsection{Unsteady Drainage-Fl ux Method}

At the Grass site, water content and matric head were measured as functions of depth and time. These data are in Appendix A, Tables A.7 and A.8, respectively. Figure 4.12 shows the water content profiles as a function of time. The maximum water content reached at the $15-\mathrm{cm}$ depth was $0.218 \mathrm{~cm}^{3} / \mathrm{cm}^{3}$. The maximum water content reached at the $180-\mathrm{cm}$ depth was

$0.142 \mathrm{~cm}^{3} / \mathrm{cm}^{3}$. These water content values are much less than the total porosity of each soil layer (approximately 0.5 for the upper layer and 0.4 for the lower layer). The tensiometer data listed in Appendix A, Table A.8 indicate near-saturated flow conditions at the maximum water content shown. These results suggest that entrapped air is preventing complete saturation, at least for the upper soil layer. The lower soil layer, which is coarser textured than the upper layer, could not be wetted to complete saturation, because the maximum flux through the upper soil layer is not sufficient to maintain saturation in the lower layer.

During infiltration, the wetting front essentially stops at the coarsegrained layer until the matric head increases (to nearly zero), at which time the larger pores in the coarser-textured zone begin to fill with water. Lateral flow will occur until this matric potential is reached. Hence, differences between the maximum water content reached in the upper and lower soi 1 layers at the Grass site can be attributed to the effect of the soi 1 layering.

According to Hillel (1980), the advance of a wetting front across a boundary from a fine-grained to a coarse-grained horizon may not be even and sudden "breakthrough flows" may occur in specific locations, where fingerlike intrusions take place. This unstable flow phenomenon has been the subject of numerous studies (e.g., Raats 1973; Philip 1975; Parlange and Hill 1976; Starr, Parlange, and Frink 1986). Preferential flow along the tensiometers installed at the Grass site would be somewhat analogous to the "breakthrough flows" described by Hillel (1980). The resulting effect could be saturated conditions immediately surrounding the tensiometer cups when the rest of the profile was actually unsaturated. For such conditions, the tensiometers 


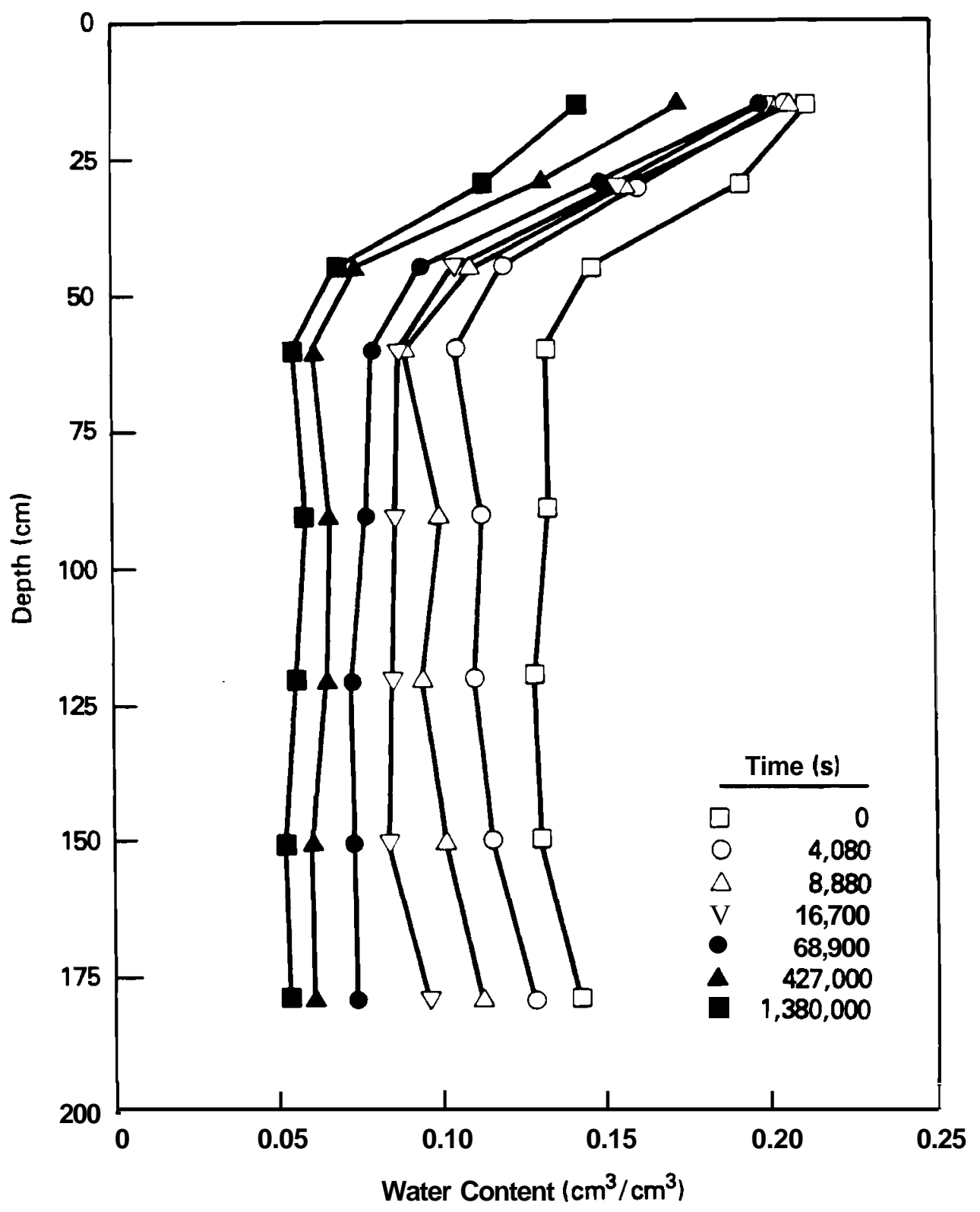

FIGURE 4.12. Water Content Profiles Observed During the Unsteady Drainage-Flux Experiment at the Grass Site

would not accurately measure matric heads in the plot profile, at least during early drainage measurements.

Figure 4.13 shows the field-measured water retention data for the Grass site. Because of entrapped or encapsulated air, complete saturation of the profile was not attained. 


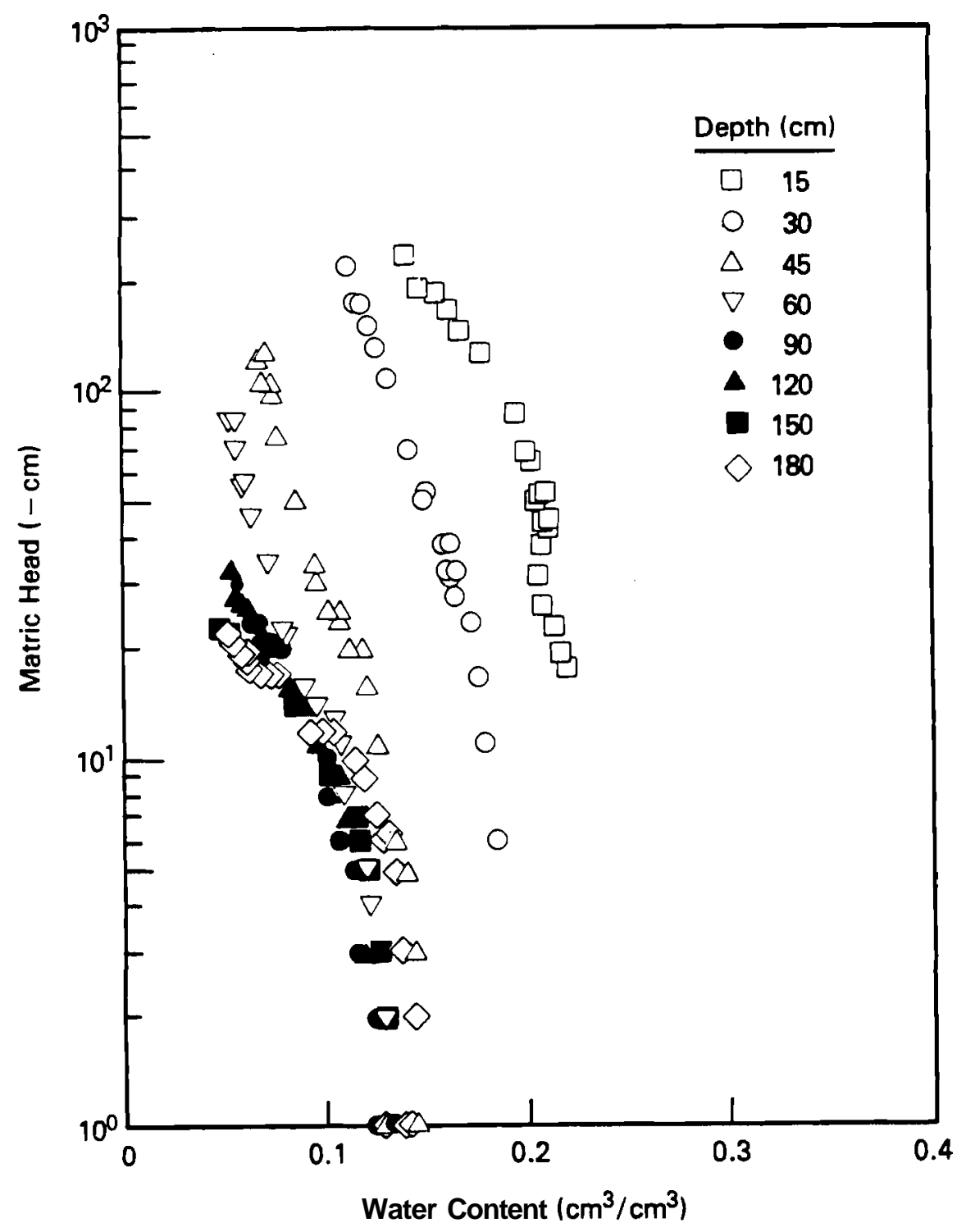

FGURE 4.13. Water Retention Data from the Unsteady DrainageFlux Experiment at the Grass Site

Figure 4.14 shows total head plotted against depth for various times during drainage at the Grass site. Note that hydraulic head values in the upper $60 \mathrm{~m}$ decreased much more rapidly than in the lower part of the soi 1 profile. This observation suggests that water moved out of the upper soil layer by some process other than drainage (e.g., evaporation, transpiration, or lateral flow). Because the plot was covered and the vegetation surrounding the plot was dormant, lateral flow is the likely cause of the hydraulic head changes. Tensiometers in the upper soil layer, 


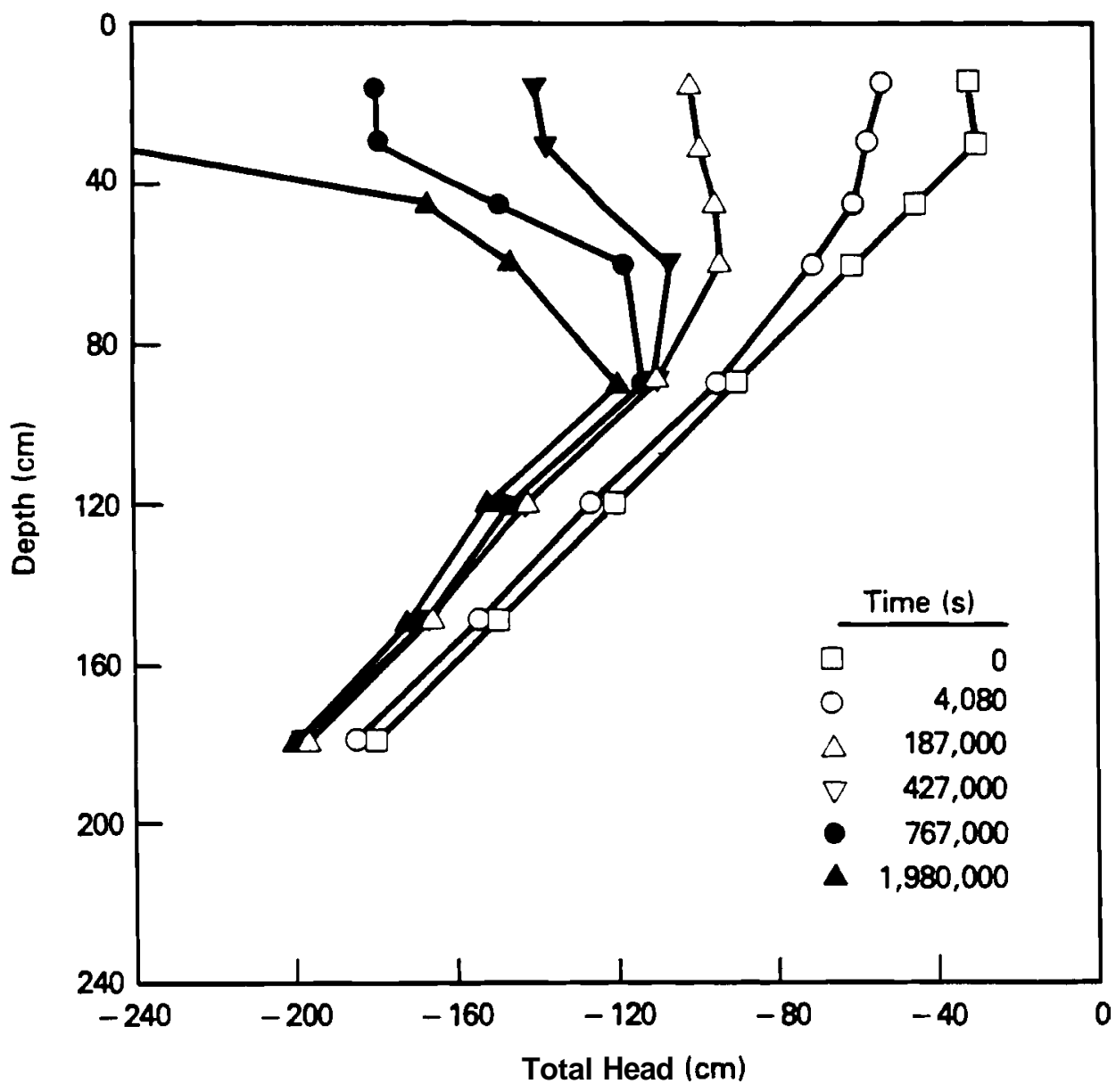

FIGURE 4.14. Hydraulic Head Profiles Observed During the Unsteady Drainage-Flux Experiment at the Grass Site

approximately $12 \mathrm{~m}$ from the test plot at the Grass site, indicated dry conditions exceeding the range of tensiometer measurement (<-800 cm) prior to running the experiment. These adjacent tensiometers were not close enough to detect lateral flow out of the study plot, but matric head gradients between the plot and the surrounding dry soil may have been great enough for water to be drawn laterally out of the upper soil layer.

An important assumption of the unsteady drainage-flux method is that lateral flow in or out of the test plot profile is negligible. This assumption is usually justified by ponding water over a large enough area for a sufficiently long period of time, so that a buffer zone is created which minimizes the lateral flow component within the test plot during drainage. This assumption is reasonable for the BWTF drainage 
experiments, where caisson walls physically restricted any lateral movement of water out of the test plot profile. However, this assumption does not appear to be justified for the drainage experiment at the Grass site. Therefore, the instantaneous profile method was not used to calculate hydraulic conductivities from these data.

The Lax solution method (Sisson, Ferguson, and van Genuchten 1980) is based on a unit gradient assumption. From Figure 4.14, it is obvious that unit gradient conditions do not exist across the entire profile, although they do appear to exist below the $60-\mathrm{cm}$ depth. The fixed gradient analysis (Sisson 1987) assumes that the hydraulic head gradient may vary by depth, but is invariant with time. However, Figure 4.14 shows that the gradient varies with time above the $60-\mathrm{cm}$ depth. Therefore, neither the Lax solution nor the fixed gradient analysis was used with the Grass Site data. Efforts are in progress to repeat this experiment, with modifications to eliminate lateral movement within the upper $60 \mathrm{~m}$ of the profile.

\subsubsection{Guelph Permeameter Method}

Results for the Guelph permeameter analyses from measurements at the Grass site are shown in Table 4.3. The mean $\mathrm{K}_{\mathrm{fs}}$ value of $0.0092 \mathrm{~cm} / \mathrm{s}$ for

TABLE 4.3. Results from the Guelph Permeameter for the Grass Site

\begin{tabular}{|c|c|c|c|}
\hline Location & $\mathrm{K}_{\mathrm{fs}}, \mathrm{cm} / \mathrm{s}$ & $\phi \mathrm{m}, \mathrm{cm}^{2} / \mathrm{s}$ & $a$ \\
\hline \multicolumn{4}{|c|}{ 20-cm depth } \\
\hline $\begin{array}{r}2 \\
3 \\
5 \\
6 \mathrm{~A} \\
7 \mathrm{~A} \\
9 \mathrm{~A} \\
10 \mathrm{~A}\end{array}$ & $\begin{array}{l}0.0002 \\
0.0006 \\
0.0008 \\
0.0009 \\
0.0014 \\
0.0025 \\
0.0007 \\
\end{array}$ & $\begin{array}{l}0.0030 \\
0.0032 \\
0.0084 \\
0.0010 \\
0.0047 \\
0.0050 \\
\underline{0.0096} \\
\end{array}$ & $\begin{array}{l}0.0667 \\
0.1875 \\
0.0952 \\
0.9000 \\
0.2979 \\
0.5000 \\
0.0729 \\
\end{array}$ \\
\hline Average & 0.0010 & 0.0050 & 0.2000 \\
\hline \multicolumn{4}{|c|}{ 60-cm depth } \\
\hline $\begin{array}{r}6 \mathrm{~B} \\
7 \mathrm{~B} \\
9 \mathrm{~B} \\
10 \mathrm{~B}\end{array}$ & $\begin{array}{l}0.0019 \\
0.0084 \\
0.0037 \\
0.0228 \\
\end{array}$ & $\begin{array}{l}0.2130 \\
0.1320 \\
0.0197 \\
0.0312 \\
\end{array}$ & $\begin{array}{l}0.0089 \\
0.0636 \\
0.1878 \\
0.7308 \\
\end{array}$ \\
\hline Average & 0.0092 & 0.0990 & 0.0929 \\
\hline
\end{tabular}


the lower soil layer is approximately 9 times larger than the mean value of $0.001 \mathrm{~cm} / \mathrm{s}$ for the upper layer. This difference supports the contention that the upper soil layer restricts water infiltration to the lower layer by limiting the flux, such that the lower layer cannot be completely saturated during an infiltration experiment.

\subsubsection{Predictions}

Particle-size distribution data from the Grass site (see Appendix B, Table B.2) will be used in the Arya and Paris (1981) and Mualem (1976) models to predict hydraulic conductivities after repeating the unsteady drainage-flux experiment at that site. This second set of data will then be available to further assess the predictive capabilities of these models in layered soil profiles.

\subsection{MCGEE RANCH}

An unsteady drainage-flux experiment was conducted at the McGee Ranch. Guelph permeameter measurements were taken around the borrow pit at the site, and within the unsteady drainage-flux test plot. Soil samples, collected from the auger holes used for Guelph permeameter measurements, were used for particle-size analysis and WRC prediction by the Arya and Paris (1981) model. These predictions were then used in the Mualem (1976) model to predict hydraulic conductivities.

\subsubsection{Unsteady Drainage-Flux Method}

The water content data for the unsteady drainage-flux experiment at the McGee Ranch are listed in Appendix A, Table A.9. The water content profiles on Figure 4.15 show that water content decreased uniformly with depth during drainage. Data from the $120-\mathrm{cm}$ depth were not analyzed, because steady-state flow had not been reached at that depth, and time constraints and water availability limited additional infiltration. After approximately 15 days of drainage, matric head values had reached -323 to $-340 \mathrm{~cm}$ for all depths under consideration (see Appendix A, Table A.10). Figure 4.16 shows total head versus depth for various times during drainage at this site. The mean head gradient is equal to 0.83 . If lateral flow were appreciable at the McGee Ranch site, it would not be as 


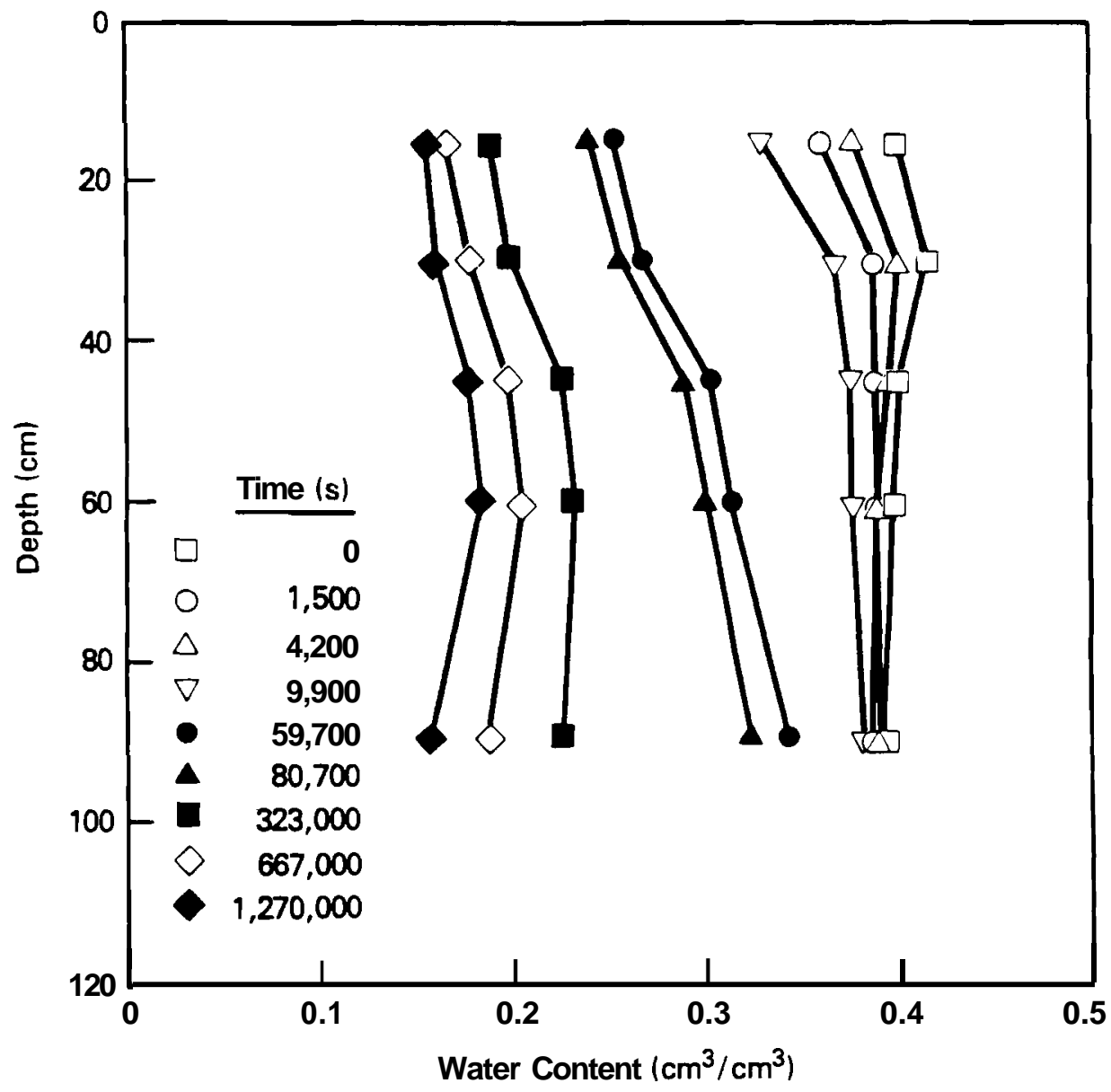

FIGURE 4.15. Water Content Profiles Observed During the Unsteady Drainage-Flux Experiment at the McGee Ranch

apparent in the total head data of Figure 4.16 as it was on Figure 4.14, because of the relative uniformity of the soil profile.

Field-measured water retention data for the McGee Ranch site are listed in Appendix A, Tables A.9 and A.10. These data are plotted on Figure 4.17. Hydraulic conductivities were calculated by a time-averaging approach (Rose, Stern, and Drummond 1965), using actual head gradients rather than an assumed unit gradient. These data are listed in Appendix A, Table A.11, and are plotted on Figure 4.18. The close grouping of the data on Figure 4.18 indicate that the upper $1 \mathrm{~m}$ of soil at this site is relatively uniform with respect to hydraul ic conductivity. 


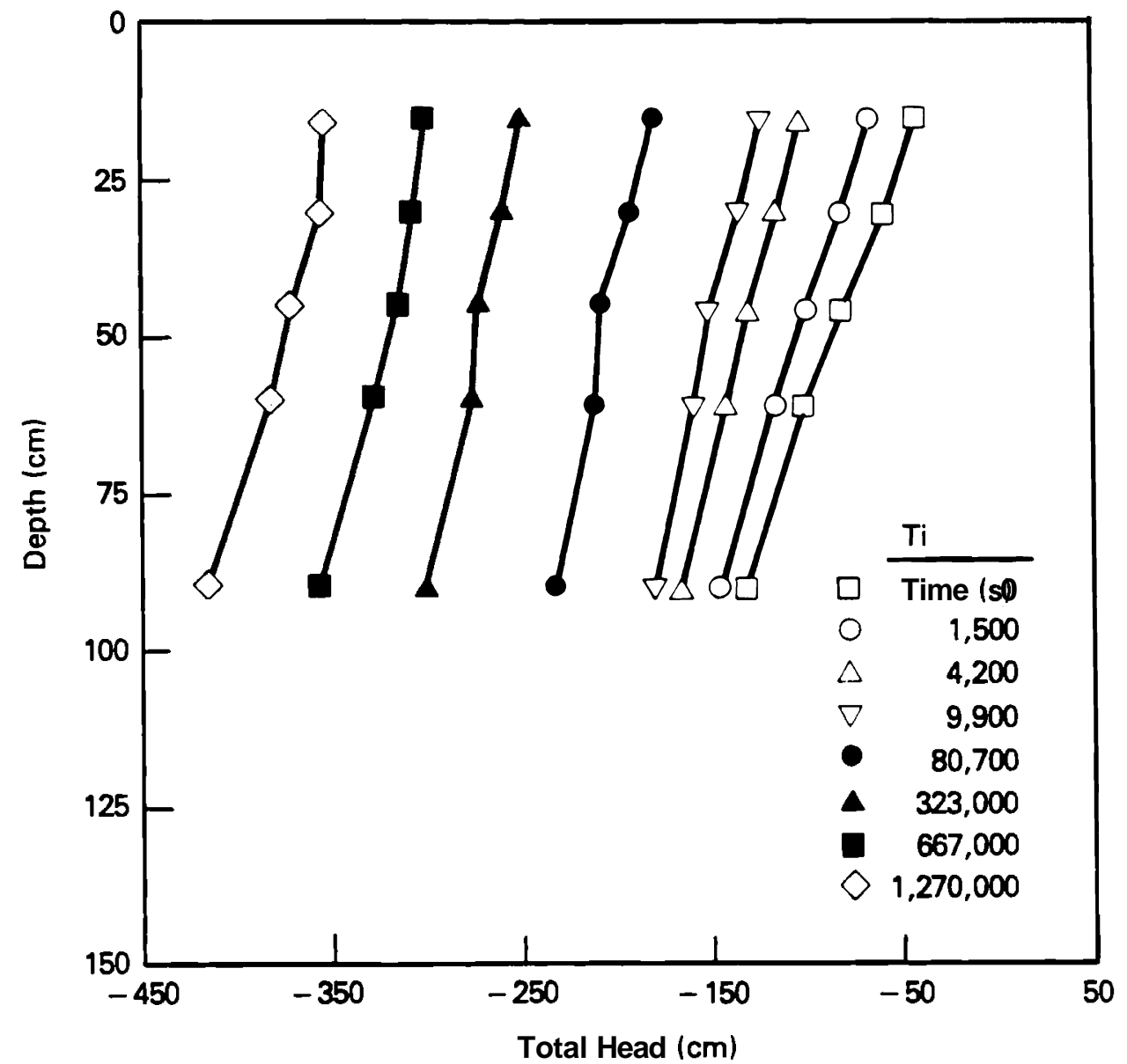

FIGURE 4.16. Hydraulic Head Profiles Observed During the Unsteady Drainage-Flux Experiment'at the MoGee Ranch

Figure 4.16 indicates that unit gradient conditions did not exist at the McGee Ranch site during the unsteady drainage-flux experiment. Based on Figure 4.16 it appears as though the gradients are relatively constant in time. Therefore, the Lax solution (Sisson, Ferguson, and van Genuchten 1980 ) and fixed gradient analysis were used to determine the parameters in the Watson (1967) model for the McGee Ranch data. Scaling of the water content data had very little effect on the regression parameters, because of the uniformity of the profile. The resulting Watson (1967) model relationship determined from this analysis is

$$
K=0.0017(\theta / 0.399)^{8.53}
$$




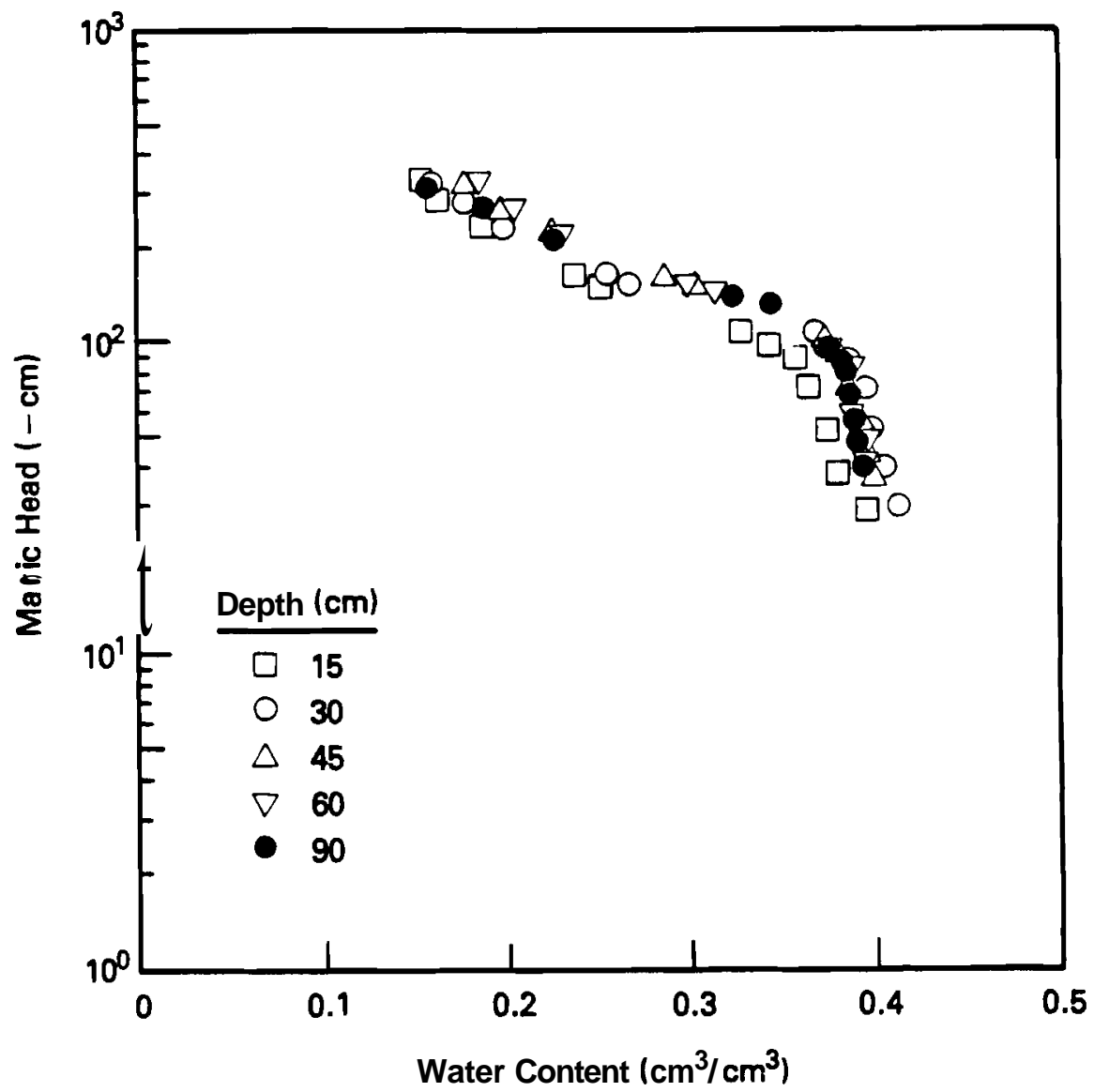

FIGURE 4.17. Water Retention Data from the Unsteady DrainageFlux Experiment at the MoGee Ranch

where $0.0017 \mathrm{~cm} / \mathrm{s}$ is the rate of fall of the level of ponded water on the surface of the test plot. The average water content for all depths at time zero was $0.399 \mathrm{~cm}^{3} / \mathrm{cm}^{3}$, and the slope of the $\log (z / t)$ versus $\log \theta$ line is 7.53. This $K(\theta)$ relationship is shown as the solid line in Figure 4.18 .

\subsubsection{Guelph Permeameter Method}

Results of analysis of the Guelph permeameter data from around the borrow pit and within the unsteady drainage-flux plot at the MoGee Ranch are shown in Table 4.4. Figure 4.19 shows the field-measured $K(h)$ data from the MoGee Ranch unsteady drainage-flux experiment. The solid line on Figure 4.19 represents the average $K(h)$ relationship determined from 


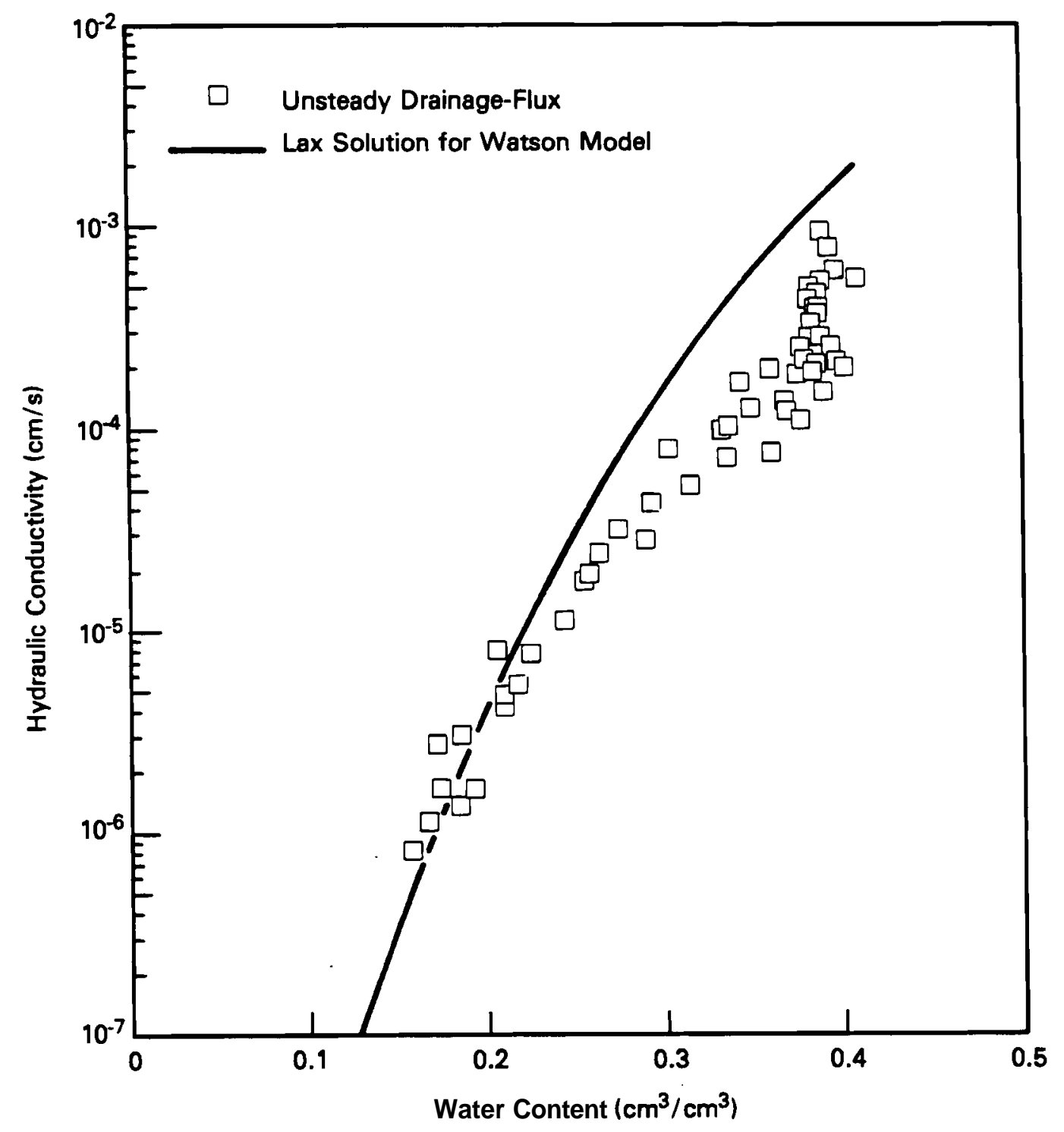

FIGURE 4.18. Hydraulic Conductivity as a Function of Water Content from the Unsteady Drai nage-Flux Experiment at the McGee Ranch

analysis of nine Guelph permeameter measurements shown in Table 4.4. The arithmetic mean value of $\mathrm{Kfs}_{\mathrm{f}}$, based on analysis of the 9 Guelph permeameter measurements, is $0.0009 \mathrm{~cm} / \mathrm{s}$. The $K f s$ val ues calculated from Guelph permeameter data for samples $9 A$ and $9 B$, which were measured within the unsteady drainage-flux study plot, are 0.0005 and $0.0007 \mathrm{~cm} / \mathrm{s}$, respectively. The $K(h)$ relationships determined from these data are also 
TABLE 4.4. Results from the Guelph Permeameter for the McGee Ranch

\begin{tabular}{|c|c|c|c|}
\hline Location & $\mathrm{K}_{\mathrm{fs}}, \mathrm{cm} / \mathrm{s}$ & $\phi_{\mathrm{m}}, \mathrm{cm}^{2} / \mathrm{s}$ & $a$ \\
\hline \multicolumn{4}{|l|}{ 20-cm depth } \\
\hline $\begin{array}{r}1 A \\
2 A \\
3 A \\
9 A \\
10 A\end{array}$ & $\begin{array}{l}0.0007 \\
0.0002 \\
0.0006 \\
0.0005 \\
0.0011 \\
\end{array}$ & $\begin{array}{l}0.0034 \\
0.0111 \\
0.0044 \\
0.0042 \\
0.0060 \\
\end{array}$ & $\begin{array}{l}0.2059 \\
0.0180 \\
0.1364 \\
0.1190 \\
0.1833 \\
\end{array}$ \\
\hline Average & 0.0006 & 0.0058 & 0.1034 \\
\hline \multicolumn{4}{|l|}{ 60-cm depth } \\
\hline $\begin{array}{l}\text { 1B } \\
3 \mathrm{~B} \\
4 \mathrm{~B} \\
9 \mathrm{~B}\end{array}$ & $\begin{array}{l}0.0024 \\
0.0004 \\
0.0015 \\
0.0007 \\
\end{array}$ & $\begin{array}{l}0.0176 \\
0.0165 \\
0.0052 \\
0.0167 \\
\end{array}$ & $\begin{array}{l}0.1364 \\
0.0242 \\
0.2885 \\
0.0419 \\
\end{array}$ \\
\hline Average & 0.0013 & 0.0140 & 0.0929 \\
\hline Overall Average & 0.0009 & 0.0095 & 0.0947 \\
\hline
\end{tabular}

plotted on Figure 4.19 as the dashed and dashed-dotted 1ines, representing samples $9 \mathrm{~A}$ and $9 \mathrm{~B}$, respectively. The slope of the line determined from analysis of Guelph permeameter results of sample $9 \mathrm{~B}$ comes closest to matching the trend of the measured hydraul ic conductivity values. There is less than an order of magnitude difference between values that fall on this line and the measured values at matric heads of about $-60 \mathrm{~cm}$. This difference increases to almost 3 orders of magnitude at a matric head of $-300 \mathrm{~cm}$. This relationship suggests that the calculation of the slope of the line comparing lognormal $\mathrm{K}$ to $\mathrm{h}$ that was used in the assumed exponential $K(h)$ relationship, may not be appropriate for the soils in this study [see Equation (2.15)]. However, this failure of the $\mathbf{k}(\mathbf{h})$ line based on analysis of Guelph permeameter data, to fit the measured $\boldsymbol{K}(\boldsymbol{h})$ data may be a result of natural soil heterogeneity within the plot and across the McGee Ranch site.

The Guel ph permeameter measures hydraul ic conductivity in the vicinity of the auger hole. The neutron probe and tensiometers measure water contents and matric heads over a larger volume of soil such that the measurements and subsequent hydraulic conductivity calculations represent 


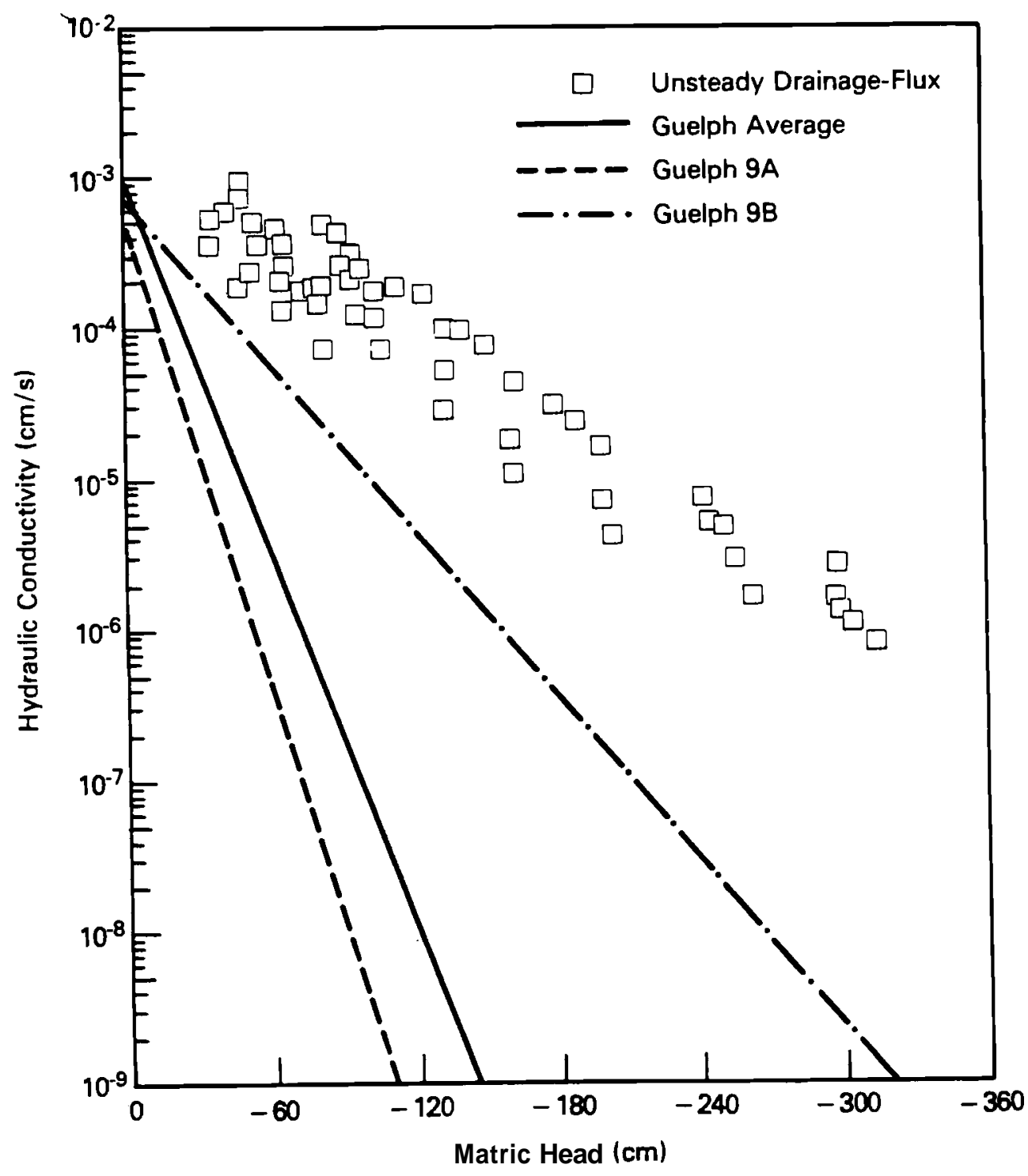

FIGURE 4.19. Hydraulic Conductivity as a Function of Matric Head from the Unsteady Drainage-Flux Experiment at the McGee Ranch and the $\mathrm{K}(\mathrm{h})$ Relationships Determined from the Average of 9 Sets of Guelph Permeameter Measurements at the McGee Ranch. Guelph 9A and 9B represent 2 sets of measurements, from the $20-\mathrm{cm}(9 \mathrm{~A})$, and $60-\mathrm{cm}(9 B)$ depths, within the unsteady drainage-flux experiment field plot

more of the natural heterogeneity. Consequently, differences in hydraulic conductivity obtained by the Guelph permeameter and unsteady drainage-flux methods likely result from spatial variability and scale differences 
between the two methods. Differences may also result from different approximations of differential and integral quantities in the two methods.

\subsubsection{Predictions}

Figure 4.20 shows field-measured water retention data from the McGee Ranch. The solid line represents a least-squares fit to the data using the RETC.F77 computer program. The dashed line curve is fit 'to predicted water retention values based on the particle-size distribution composited from samples MCG-9A and -9B (listed in Appendix B, Table B.3). These samples were collected from the $20-$ and $60-\mathrm{cm}$ depths within the unsteady drainage-flux study plot at the McGee Ranch. The measured bulk density of $1.54 \mathrm{~g} / \mathrm{cm}^{3}$ and particle density of $2.77 \mathrm{~g} / \mathrm{cm}^{3}$ were used with the "a" parameter in the Arya and Paris (1981) model set at 1.38 to calculate predicted water retention values. The dashed-dotted line on Figure 4.20 is fit to predicted water retention values based on the same particle-size distribution, with the same bulk and particle densities, but with $\mathrm{a}=$ 1.10. This value was determined by visual fit of a curve to the measured data. With $\mathrm{a}=1.10$, the predicted water retention values agree with the measured data within a factor of 3 of matric head values, between water contents of approximately 0.10 to $0.40 \mathrm{~cm}^{3} / \mathrm{cm}^{3}$.

Figure 4.21 shows field-measured hydraul ic conductivity data from the unsteady drainage-flux experiment at the McGee Ranch. The solid curve was fit to field-measured water retention data using the RETC. F77 computer program with Mualem's (1976) predictive conductivity model. The Ks value was fixed at $0.0012 \mathrm{~cm} / \mathrm{s}$, which is 2 times the average $\mathrm{K}_{\mathrm{fs}}$ value for samples MCG-9A and -9B, as determined by analysis of the Guelph permeameter data. The curve does not fit the measured data very well. As mentioned previously, a much closer fit to the measured data can be obtained with RETC.F77 if $\mathrm{m}$ and $\ell$ are fitted independently and/or if a simultaneous fit to retention and hydraulic conductivity data is made. The fit could probably also be improved if more data for the drier portion of the range of soil moisture conditions were available. The RETC.F77 program fit the $\theta_{r}$ value at $0.0 \mathrm{~cm}^{3} / \mathrm{cm}^{3}$. This value would be difficult, if not impossible, to reach under field conditions. 


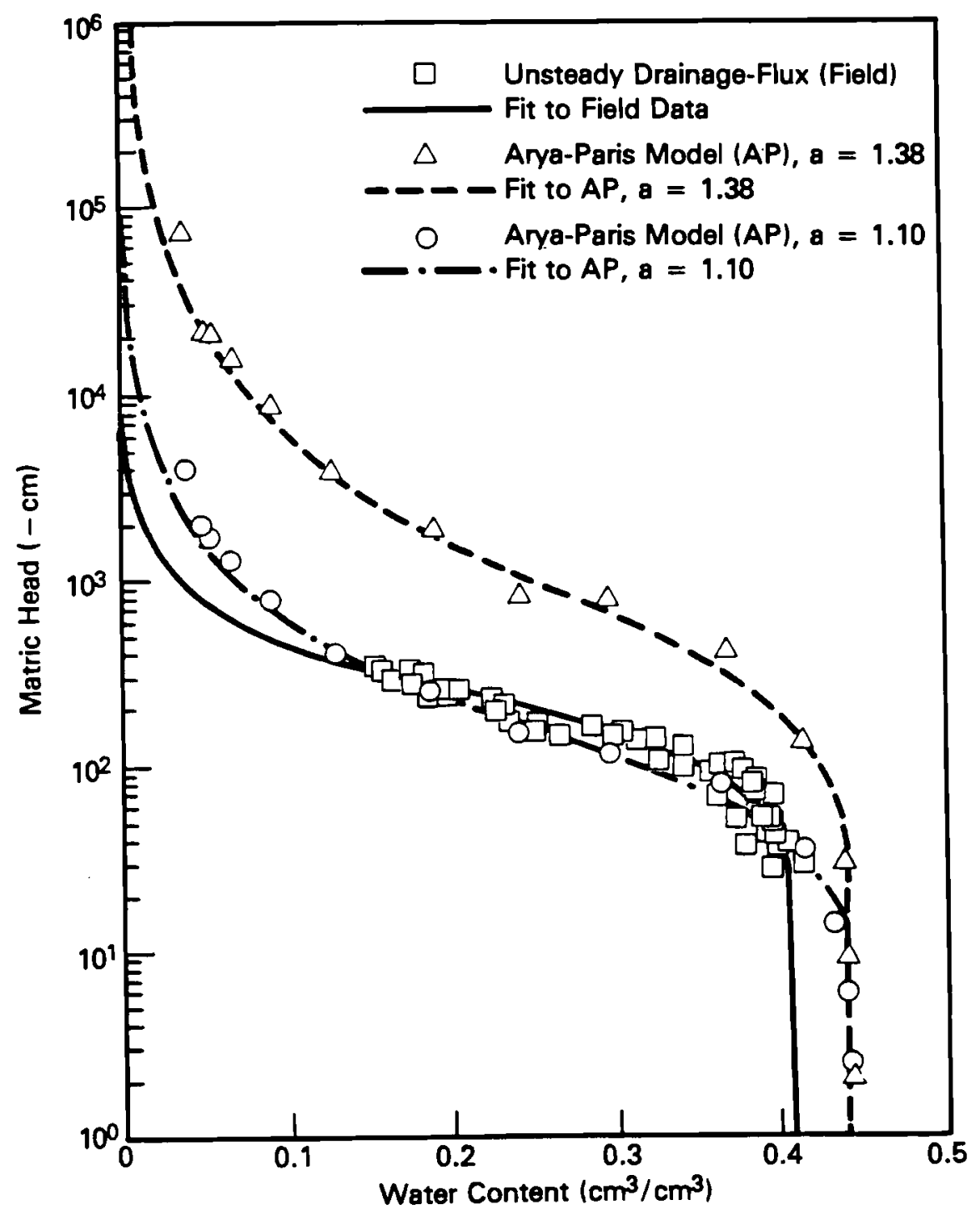

FIGURE 4.20. Water Retention Curves Fit to Data from the Unsteady Drainage-Flux Experiment at the McGee Ranch and to Water Retention Characteristics Predicted by the Arya-Paris (AP) (1981) Model. Predicted values were generated from a composite particle-size distribution o.f Samples $9 \mathrm{~A}$ and $9 \mathrm{~B}$ with the AP model "a" $=1.38$ and 1.10

The dashed line shown on Figure 4.21 corresponds to the dashed line on Figure 4.20, which is based on Arya and Paris (1981) model predictions with $\mathrm{a}=1.38$. The dashed-dotted line on Figure 4.21 corresponds to the dashed-dotted line on Figure 4.20 with $a=1.10$. Both of these lines match measured hydraulic conductivity data within a factor of five up to a 


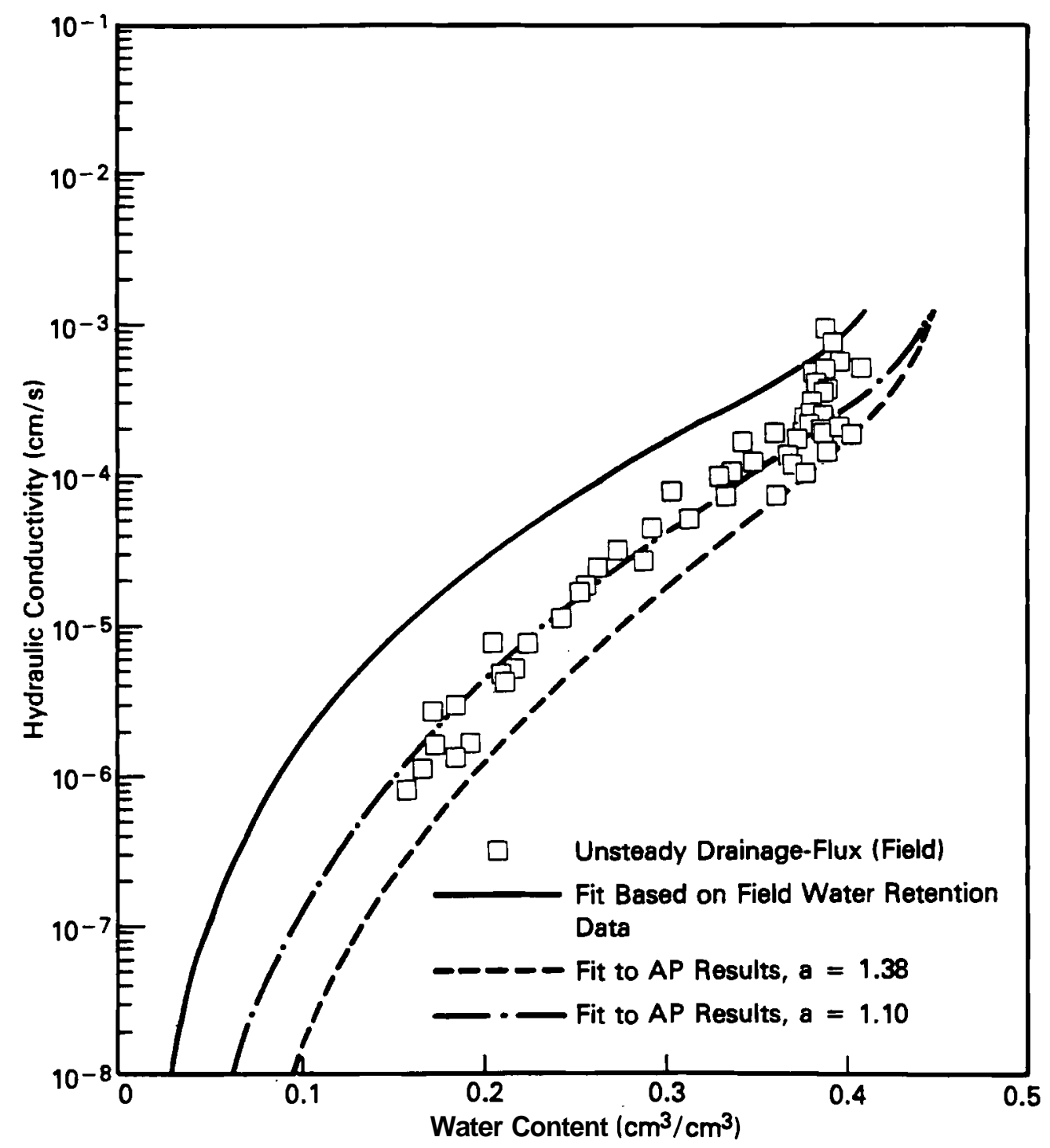

FIGURE 4.21. Hydraulic Conductivity as a Function of Water Content from the Unsteady Drainage-Flux Experiment at the McGee Ranch and Predicted Curves Based on the AryaParis (AP) (1981) Model Results Shown in Figure 4.20

water content of approximately $0.40 \mathrm{~cm} 3 / \mathrm{cm}^{3}$. The value of $\mathrm{a}=1.10$ gives a much better fit to measured water retention and hydraulic conductivity data than $a=1.38$. These curves were generated by fixing the $\mathbf{K}_{\mathbf{s}}$ value at $0.0012 \mathrm{~cm} / \mathrm{s}$ as was done with the curve $\mathrm{fit}$ to measured data. The $\theta_{\mathbf{s}}$ value for these curves was fixed at a water content value of $0.444 \mathrm{~cm}^{3} / \mathrm{cm}^{3}$ (determined from the particle and bulk densities), but the $\theta_{\mathbf{s}}$ value for 
the curve fit to measured data was fitted by the program at a water content value of $0.392 \mathrm{~cm} 3 / \mathrm{cm}^{3}$. Therefore, differences between measured and predicted conductivities at water contents above $0.392 \mathrm{~cm} 3 / \mathrm{cm}^{3}$ do not necessarily reflect on the predictive ability of the Arya and Paris (1981) model. Table 4.5 shows the RETC.F77 curve-fitting results for MoGee Ranch data.

In the sense that the "a" parameter is empirically determined, the Arya and Paris (1981) model is not truly predictive. However, Arya and Paris used an iterative procedure to determine a best-fit "a" (1.38) that minimized the sum of the absolute value of the log of the measured matric head values minus the $\log$ of the calculated matric head values for a range of soils. They then used this value for predicting water retention values

TABLE 4.5. Curve-Fitting Results from the RETC.F77 Computer Program Based on Data from the MoGee Ranch

\begin{tabular}{|c|c|c|c|c|c|c|c|}
\hline \multirow[b]{2}{*}{ Data Set } & \multirow[b]{2}{*}{$\theta_{r}$} & \multicolumn{5}{|c|}{ Parameters $(a)$} & \multirow[b]{2}{*}{$K_{S}$} \\
\hline & & $\theta_{s}$ & $\mathrm{a}$ & $\mathrm{m}$ & $\mathrm{n}$ & 1 & \\
\hline $\begin{array}{l}\text { MoGee Ranch Water } \\
\text { Retention Data }\end{array}$ & 0.000 & 0.409 & 0.0058 & $\mathbf{R}$ & 2.3563 & $0.5^{\star}$ & $0.0012^{*}$ \\
\hline $\begin{array}{l}\text { Simultaneous Fit } \\
\text { to McGee Ranch } \\
\text { Water Retention } \\
\text { and Conductivity } \\
\text { Data }\end{array}$ & 0.019 & 0.409 & 0.0059 & $\mathrm{R}$ & 2.4299 & 1.897 & 0.0006 \\
\hline $\begin{array}{l}\text { AP-Predicted } \\
\text { Water Retention } \\
\text { Based on Samples } \\
\text { MCG-9A and -9B } \\
(\mathrm{a}=1.38)\end{array}$ & 0.000 & $0.444^{\star}$ & 0.0024 & $\mathrm{R}$ & 1.5420 & $0.5^{\star}$ & $0.0012^{*}$ \\
\hline $\begin{array}{l}\text { AP-Predicted } \\
\text { Water Retention } \\
\text { Based on Samples } \\
\text { MCG-9A and -9B } \\
(\mathrm{a}=1.65)\end{array}$ & 0.000 & $0.444^{\star}$ & 0.0110 & $\mathbf{R}$ & 1.7619 & $0.5^{\star}$ & $0.0012^{*}$ \\
\hline
\end{tabular}

(a) See Section 2.2 for Parameter definitions.

$\mathrm{AP}=$ Arya and Paris (1981) model

$\underset{\star}{R}=$ Mualem (1976) based restriction, $m=1-1 / \mathrm{n}$

$=$ Value was fixed 
for other soils in their study. They did not use water retention predictions for estimating hydraulic conductivities, however. For the soils studied here, the best-fit "a" value differs from the value of 1.38 determined by Arya and Paris. This observation raises the question of whether a single value of "a" would be appropriate for predicting water retention characteristics and subsequently predicting hydraulic conductivity for all Hanford Site soils. The question can be answered only by analyzing additional Hanford Site soils.

Differences between measured and predicted water retention values could be real, thereby suggesting limitations in the Arya and Paris (1981) model, or they could result from errors in the particle-size analysis or bulk density measurements. According to Arya and Paris, uncertainties of $\pm 5 \%$ in the particle-size analysis and t0.1 $\mathrm{g} / \mathrm{cm}^{3}$ in the bulk density are not uncommon (e.g., Coel ho 1974; Keisling 1974; Alexander 1980). A7so, an iterative procedure, such as that used by Arya and Paris, could be used to calibrate the model to optimize the fit of predicted values to measured data for the soils in this study. This should help reduce the differences between measured and predicted hydraulic conductivities. Other possible explanations for the variations between measured and predicted conductivities are differences in the field- and laboratory-tested soil materials, withinplot variability, and the initial parameter estimates used in the curvefitting process. 


\subsection{CONCLUSIONS AND RECOMMENDATIONS}

The most important conclusion, based on the results of this study, is that no single method or measurement technique should be used for generating unsaturated hydraulic conductivity data for the Hanford Site. Each method used in this study produced results sufficiently different from the other methods, that to rely solely on one method would be unwise. The most appropriate method ultimately depends on the specific job or application. Ideally, more than one method should be used to take advantage of the strengths of each method, considering the data needs and resources available.

The laboratory steady-state flux control method provided accurate hydraulic conductivity measurements for repacked columns of L-soil from the Buried Waste Test Facility. These measurements agreed with field measurements within one order of magnitude. Using repacked columns may not yield results that are truly representative of natural conditions at other sites because of the disturbed nature of the samples. Therefore, using this method with undisturbed core samples would be preferable, and tests should be initiated using this method with undisturbed samples from the other field sites. This method is time consuming. It has an advantage, however, over other methods in that samples can be completely saturated so that true desorption curves, rather than intermediate scanning curves, can be measured.

The unsteady drainage-flux method provided relatively accurate hydraulic conductivity measurements at two of the three field sites. At the third site (Grass site), a textural transition (i .e., layering) resulted in lateral flow, so that the one-dimensional (vertical) flow assumption used to calculate hydraulic conductivity was not valid. This experiment is being repeated with modifications to ensure one-dimensional flow.

A power function relationship, using parameters estimated by the Lax (1972) solution (Sisson, Ferguson, and van Genuchten 1980), provided reasonable descriptions of the measured hydraul ic conductivity data from the BWTF and McGee Ranch sites. Scaling of water content data with a fixed gradient model (Sisson 1987) appears to be useful as a data reduction technique and for describing some layered soil profiles. The RETC.F77 computer program 
(van Genuchten 1985) provides accurate descriptions of measured data, especially when no restrictions are imposed on the curve-fitting parameters.

The Guelph permeameter method provides rapid, relatively accurate, field-saturated hydraulic conductivity data. Because of the portability of the apparatus, low water requirements, and speed with which measurements can be made, this method should be useful for spatial variability studies. The adequacy of the method for describing the $K(h)$ relationships of soils tested in this study, however, remains questionable. The failure of the $\boldsymbol{k}(\mathrm{h}) \mathrm{rela}-$ tionship determined from Guelph permeameter analyses to agree with other measured data may be a result of natural soil heterogeneity and scale differences between methods.

The predictions of hydraulic conductivity based on particle-size distribution and bulk density data were within one-half to one and one-half orders of magnitude of measured values, depending on soil type. This agreement may or may not be considered adequate, depending on the nature of the information needs, but the technique could be useful as a first approximation of hydraulic conductivity and would allow use of the Westinghouse Hanford Company grain-size data base.

The differences in hydraulic conductivities measured by the various techniques in this study illustrate several unresolved problems. One of these is how to reconcile laboratory and field data that have different $\mathbf{K}_{\mathbf{s}}$ and $\boldsymbol{\theta}_{\mathbf{s}}$ values; this is often attempted by scaling data or by using matching factors. With hysteresis effects resulting from incomplete saturation because of entrapped air, field-measured water retention curves wi 11 have different shapes than those measured in the laboratory regardless of matching factors. Consequently, it is not realistic to expect complete agreement between 1 aboratory and field data.

Field data are generally considered to be more representative of natural conditions and, thus, are preferable to laboratory data. On a large scale, it becomes impractical to try to characterize the variability of soil hydraulic properties with the detailed analyses used in this study. Therefore, geostatistical approaches should be evaluated as a means of using a small set of data to characterize large areas. 


\subsection{REFERENCES}

Alexander, E. B. 1980. "Bulk Densities of California Soils in Relation to Other Soil Properties." Soil Sci. Soc. Am J. 44:689-692.

Arya, L. M., and J. F. Paris. 1981. "A Physicoempirical Model to Predict the Soil Moisture Characteristic from Particle-Size Distribution and Bulk Density Data." Soil Sci. Soc. Am. J. 45:1023-1030.

Black, T. A., W. R. Gardner, and G. W. Thurtell. 1969. "The Prediction of Evaporation, Drainage, and Soil Water Storage for a Bare Soil." Soil Sci. Soc. Am. Proc. 33:655-660.

Cass, A., G. S. Campbell, and T. L. Jones. 1981. Hydraulic and Thermal Properties of Soil Samples from the Buried Waste Test Facility. PNL-4015, Pacific Northwest Laboratory, Richland, Washington.

Coelho, M. A. 1974. Spatial Variability of Water Related Soil Physical Properties. Ph.D. Thesis, University of Arizona. University Microfilms, Ann Arbor, Michigan (Diss. Abstr. 75-11061).

Davidson. J. M.. L. R. Stone, D. R. Nielsen, and M. E. LaRue. 1969. "Field Measurement and Use of Soil-Water Properties." Water Resour. Res. $5: 1312-1321$.

Fayer, M. J., G. W. Gee, and T. L. Jones. 1986. UNSAT-H Version 1.0: Unsaturated Flow Code Documentation and Applications for the Hanford Site. PNL-5899, Pacific Northwest Laboratory, Richland, Washington.

Gardner, W. R. 1958. "Some Steady-State Solutions of the Unsaturated Moisture Flow Equation with Application to Evaporation from a Water Table." Soil Sci. 85(4) $=228-232$.

Gee, G. W., and J. W. Bauder. 1986. "Particle-Size Analysis." In Methods of Soil Analysis, Part I- 2nd ed. Editor A. Klute, pp. 383-411. American Society of Agronomy, Madison, Wisconsin.

Gee, G. W., and R. R. Kirkham. 1984. Arid Site Water Balance: Evapotranspiration Modeling and Measurements. PNL-5177, Pacific Northwest Laboratory, Richland, Washington.

Green, R. E., L. R. Ahuja, and S. K Chong. 1986. "Hydraulic Conductivity, Diffusivity, and Sorptivity of Unsaturated Soils: Field Methods. "In Methods of Soil Analysis, Part I- 2nd ed. Editor A Klute, pp. 771-798. American Society of Agronomy, Madison, Wisconsin.

Gupta, S. C., and W. E. Larson. 1979. "Estimating Soil-Water Retention Characterfstics from Particle-Size Distribution, Organic Matter Percent, and Bulk Density." Water Resour. Res. 15:1633-1635. 
Hall, D. G. M., M. J. Reeve, A. J. Thomasson, and V. F. Wright. 1977. Water Retention, Porosity, and Density of Field Soils. Tech. Monograph No. 9, Rothamsted Experiment Station, Harpenden, England.

Hillel, D. 1980. Fundamentals of Soil Physics. Academic Press, New York.

Keisling, T. C. 1974. Precision with Which Selected Physical Properties of Similar Soils can be Estimated. Ph.D. Thesis, Oklahoma State University., University Microfilms, Ann Arbor, Michigan. (Diss. Abstr. 75-8812) .

Kirkham, R. R., and G. W. Gee. 1987. Field Lysimeter Test Facility for Protective Barriers: Experimental Plan. PNL-6351, Pacific Northwest Laboratory, Richland, Washington.

Klute, A. 1986. "Water Retention: Laboratory Methods." In Methods of Soil Analysis, Part I. 2nd ed. Editor A. Klute, pp. 635-662. American Society of Agronomy, Madison, Wisconsin.

Klute, A., and C. Dirksen. 1986. "Hydraulic Conductivity and Diffusivity: Laboratory Methods." In Methods of Soil Analysis, Part I. 2nd ed. Editor A. Klute, pp. 687-734. American Society of Agronomy, Madison, Wisconsin.

Last, G. V., M. A. Glennon, M. A. Young, and G. W. Gee, 1987. Protective Barrier Materials Analysis: Fine Soil Site Characterization. PNL-6314, Pacific Northwest Laboratory, Richland, Washington

Lax, P. D. 1972. "The Formation and Decay of Shock Waves." Am. Math Monthly 79:227-241.

Mualem, Y. 1976. "A New Model for Predicting the Hydraulic Conductivity of Unsaturated Porous Media." Water Resour. Res. 12(3):513-522.

Mualem, Y. 1986. "Hydraulic Conductivity of Unsaturated Soils: Prediction and Formulas." In Methods of Soil Analysis, Part I. 2nd ed. Editor A. Klute, pp. 799-823. American Society of Agronomy, Madison, Wisconsin.

Nielsen, D. R., J. W. Biggar, and K. T. Erh. 1973. "Spatial Variability of Field-Measured Soil-Water Properties." Hilgardia 42:215-259.

Nielsen, D. R., J. M. Davidson, J. W. Biggar, and R. J. Miller. 1964. "Water Movement Through Panoche Clay Loam Soil." Hilqardia 35:491-506.

Parlange, J. -Y., and D. E. Hill. 1976. "Theoretical Analysis of Wetting Front Instability in Soils." Soi 1 Sci. 122:236-239.

Philip, J. R. 1975. "Stability Analysis of Infiltration." Soil Sci. Soc. Amer. Proc. 39:1042-1049. 
Phillips, S. J., A C. Campbell, M. D. Campbell, G. W. Gee, H. H. Hoober, and K. 0. Schwartzmiller. 1979. A Field Test Facility for Monitoring Water/ Radionuclide Transport Through Partially Saturated Geologic Media: Desian, Construction, and Preliminary Description. PNL-3226, Pacific Northwest Laboratory, Richland, Washington.

Raats, P. A. C. 1973. "Unstable Wetting Fronts in Uniform and Nonuniform Soils." Soil Sci. Soc. Amer. Proc. 37:681-685.

Reynolds, W. D., and D. E. Elrick. $1985 . \quad$ "In-Situ Measurement of FieldSaturated Hydraulic Conductivity, Sorptivity and the a-Parameter Using the Guelph Permeameter." Soil Sci. 140:292-302.

Reynolds, W. D., D. E Elrick, and B. E. Clothier. 1985. "The Constant Head Wel1 Permeameter: Effect of Unsaturated Flow." Soil Sci. 139(2):172-180.

Richards, L. A 1931. "Capillary Conduction of Liquids in Porous Mediums." Physics 1:318-333.

Richards, L. A., W. R. Gardner, and G. Ogata. 1956. "Physical Processes Determining Water Loss from Soil." Soil Sci. Soc. Am. Proc. 20:310-314.

Rose, C. W., W. R. Stern, and J. E Drummond. 1965. "Determination of Hydraulic Conductivity as a Function of Depth and Water Content for Soil in Situ." Aust. J. Soil Res. 3:1-9.

Scotter, D. R., B. E. Clothier, and E. R. Harper. 1982. "Measuring Saturated Hydraulic Conductivity and Sorptivity Using Twin Rings." Aust. J. Soil Res. 20(4):295-304.

Sisson, J. B. 1987. "Drainage from Layered Field Soils: Fixed Gradient Models." Water Resour. Res. 23(11) :2071-2075.

Sisson, J. B., A. H. Ferguson, and M. Th. van Genuchten. 1980. "Simple Method for Predicting Drainage from Field Plots." Soil Sci. Soc. Am. J. $44: 1147-1152$.

Starr, J. L., J. -Y. Parlange, and C. R. Frink. 1986. "Water and Chloride Movement Through a Field Soil." Soil Sci. Soc. Am. J. 50:1384-1390.

Stephens, D. B., S. Tyler, K. Lambert, and S. Yates. 1983. "Field Experiments to Determine Saturated Hydraulic Conductivity in the Vadose Zone." In Role of the Unsaturated Zone in Radioactive and Hazardous Waste Disposal. Editor J. W. Mercer. Ann Arbor Science, Ann Arbor, Michigan, pp. 113-126.

Stephens, D. B., K. Lambert, and D. Watson. 1984. "Influence of Entrapped A ir on Field Determinations of Hvdraulic Properties in the Vadose Zone." Proc. Conf. Characterization and Monitoring in the Vadose Zone. National Water We11 Association, Worthington, pp. 57-76. 
U.S. Department of Energy. 1987. Final Environmental Impact Statement, Disposal of Hanford Defense High-Level, Transuranic and Tank Wastes, Hanford Site, Richland, Washington. DOE/EIS-0113F (Vol. 3), U.S. Department of Energy, Washington, D.C.

van Genuchten, M. Th. 1978. Calculating the Unsaturated Hydraulic Conductivity with a New Closed-Form Analytical Model. Report 78-WR-08, Department of Civil Engineering, Princeton, New Jersey, pp. 63.

van Genuchten, M. Th. 1985. Program to Analyze Observed Soil Water Tension and Hydrauli c Conductivity Data. U.S. Salinity Laboratory Special Report, Riverside, California.

Watson, K. K. 1966. "An Instantaneous Profile Method for Determining the Hydraulic Conductivity of Unsaturated Porous Materials." Water Resour. Res. 1:577-586.

Watson, K. K. 1967. "The Measurement of the Hydraulic Conductivity of Unsaturated Porous Materials Utilizing a Zone of Entrapped Air." Soil Sci. Soc. Am. Proc. 32:716-720.

Wierenga, P. J., L. W. Gelhar, C. S. Simmons, G. W. Gee, and T. J. Nicholson. 1986. Validation of Stochastic Flow and Transport Models for Unsaturated Soi 1s: A Comprehensive Field Study. NUREG/CR-4622, U.S. Nuclear Regulatory Commission, Washington D.C. 
APPENDIX A

WATER RETENTION AND HYDRAULIC CONDUCTIVITY DATA 
APPENDIX A

WATER RETENTION AND HYDRAULIC CONDUCTIVITY DATA

TABLE A.1. Steady-State Flux Control Method Results for L-Soil

\begin{tabular}{|c|c|c|}
\hline$\frac{\text { Col umn }}{8, \mathrm{~cm}^{3} / \mathrm{cm}^{3}}$ & $\begin{array}{l}p b=1 . \\
h, a m\end{array}$ & $\mathrm{~K}, \mathrm{~cm} / \mathrm{s}$ \\
\hline 0.435 & $\approx 0$ & $7.62 E-3$ \\
\hline 0.308 & 18 & $1.74 \mathrm{E}-3$ \\
\hline 0.233 & 21 & $7.89 \mathrm{E}-4$ \\
\hline 0.173 & 29 & $1.01 \mathrm{E}-4$ \\
\hline 0.129 & 47 & $1.32 \mathrm{E}-5$ \\
\hline 0.100 & 83 & $1.09 \mathrm{E}-6$ \\
\hline 0.086 & 140 & $7.70 \mathrm{E}-8$ \\
\hline
\end{tabular}

\begin{tabular}{|c|c|c|c|c|c|}
\hline \multicolumn{3}{|c|}{ Column $E_{,} \rho \mathrm{h}=1.7 \mathrm{~g} / \mathrm{cm}^{3}$} & \multicolumn{3}{|c|}{ Column $F, \rho b=1.7 \mathrm{~g} / \mathrm{cm}^{3}$} \\
\hline $8, \mathrm{~cm}^{3} / \mathrm{cm}^{3}$ & $h, a m$ & $\underline{\mathrm{K}}, \mathrm{cm} / \mathrm{s}$ & $\underline{0, \mathrm{~cm}^{3} / \mathrm{cm}^{3}}$ & $\mathrm{~h}, \mathrm{an}$ & $\underline{\mathrm{k}}, \mathrm{cm} / \mathrm{s}$ \\
\hline 0.400 & $\approx 0$ & $7.12 E-3$ & 0.386 & $\approx 0$ & $8.91 \mathrm{E}-3$ \\
\hline 0.307 & 20 & $2.57 E-3$ & 0.297 & 20 & $2.52 E-3$ \\
\hline 0.227 & 23 & $5.15 \mathrm{E}-4$ & 0.229 & 23 & $5.07 E-4$ \\
\hline 0.189 & 35 & $1.72 E-4$ & 0.186 & 35 & $1.68 \mathrm{E}-4$ \\
\hline 0.145 & 52 & $2.15 \mathrm{E}-5$ & 0.155 & 42 & $4.23 E-5$ \\
\hline 0.125 & 72 & $5.32 \mathrm{E}-6$ & 0.124 & 76 & $4.98 E-6$ \\
\hline 0.100 & 130 & $3.36 \mathrm{E}-7$ & 0.100 & 125 & $3.47 \mathrm{E}-7$ \\
\hline 0.091 & 175 & $1.08 \mathrm{E}-7$ & 0.092 & 170 & $1.12 E-7$ \\
\hline 0.083 & 215 & $5.40 \mathrm{E}-8$ & 0.086 & 200 & $5.58 \mathrm{E}-8$ \\
\hline
\end{tabular}

\footnotetext{
8 = volumetric water content

$\mathrm{h}=$ matric head

$\mathrm{K}=$ hydraulic conductivity

$\rho b=$ bulk density.
}

\begin{tabular}{|c|c|c|}
\hline $\begin{array}{r}\text { Column } \\
\underline{0, \mathrm{~cm}^{3} / \mathrm{cm}^{3}}\end{array}$ & $\begin{array}{l}\rho b=1 . \\
h, a m\end{array}$ & $\frac{/ \mathrm{cm}^{3}}{\mathrm{~K}, \mathrm{~cm} / \mathrm{s}}$ \\
\hline 0.422 & $\approx 0$ & $9.78 \mathrm{E}-3$ \\
\hline 0.310 & 18 & $3.16 \mathrm{E}-3$ \\
\hline 0.250 & 22 & $9.90 \mathrm{E}-4$ \\
\hline 0.177 & 29 & $1.01 \mathrm{E}-4$ \\
\hline 0.138 & 47 & $1.36 \mathrm{E}-5$ \\
\hline 0.110 & 84 & $1.59 \mathrm{E}-6$ \\
\hline
\end{tabular}




\section{TABLE A.2. Water Content Data from BWIF Southeast Caisson}

Water Content, $\mathbf{c m}^{3} / \mathbf{c m}^{3}$, at Depth, $\mathbf{c m}$

\begin{tabular}{|c|c|c|c|c|c|c|c|c|c|c|c|}
\hline Time, $\mathbf{s}$ & 45 & 68 & 75 & 98 & 185 & 128 & 135 & 158 & 186 & 210 & 240 \\
\hline $8 . \theta 0 E+\theta 0$ & 6.301 & 0.363 & 6.272 & 8.248 & 8.256 & 8.248 & 8.243 & 8.246 & 6.257 & 6.258 & 6.250 \\
\hline $4.84 E+82$ & 0.362 & 6.363 & 6.257 & 8.238 & 8.247 & 8.242 & 8.238 & 0.243 & 0.255 & 0.280 & 0.248 \\
\hline $1.08 \mathrm{E}+63$ & 0.276 & 6.291 & 6.250 & 8.225 & 8.231 & 8.232 & 8.231 & 8.229 & 0.247 & 6.258 & 6.245 \\
\hline $1.68 E+03$ & 0.252 & ø. 272 & 0.246 & 8.212 & 8.219 & 8.218 & 8.218 & 8.224 & 0.238 & 6.245 & 6.238 \\
\hline $2.28 E+03$ & 6.241 & 0.266 & 6.234 & 8.281 & 8.215 & 8.289 & 8.286 & 8.216 & 0.223 & 0.238 & 6.233 \\
\hline $2.88 \mathrm{E}+63$ & 6.226 & 0.245 & 0.223 & 8.189 & 8.281 & 8.281 & 8.283 & 8.284 & 6.217 & 6.232 & 0.226 \\
\hline $3.48 \mathrm{E}+63$ & 0.219 & 0.231 & 0.215 & 0.187 & 8.193 & 8.192 & 8.194 & 8.197 & 0.267 & 0.227 & 0.216 \\
\hline $4.38 E+83$ & 6.216 & 0.223 & 6.211 & 8.182 & 8.186 & 8.188 & 8.185 & 0.191 & 0.262 & 0.213 & 6.208 \\
\hline $7.98 E+63$ & 6.196 & 0.204 & 6.199 & 8.167 & 8.172 & 8.176 & 8.176 & 8.175 & 0.183 & 0.198 & 0.186 \\
\hline $8.88 E+63$ & 6.178 & 0.194 & 0.186 & 8.163 & 8.168 & 8.167 & 8.165 & 8.168 & 0.176 & 0.186 & 0.179 \\
\hline $1.43 E+64$ & 6.183 & 0.176 & 0.174 & 8.158 & 8.153 & 8.163 & 8.154 & 8.166 & D. 160 & 0.171 & 0.164 \\
\hline $1.79 E+94$ & 0.160 & D. 166 & 0.169 & 8.147 & 8.151 & 8.147 & 8.151 & 8.151 & 0.155 & 0.168 & 0.158 \\
\hline $2.22 E+64$ & 6.151 & 0.165 & 0.158 & 8.142 & 8.141 & 8.142 & 8.143 & 8.146 & 6.152 & 0.159 & 0.151 \\
\hline $2.65 E+64$ & 6.148 & 6.162 & 0.156 & 8.148 & 8.148 & 8.143 & 8.139 & 8.143 & 6.147 & 6.155 & 6. 149 \\
\hline $8.16 E+64$ & 6.132 & 6.141 & c.134 & 8.121 & 8.123 & 8.128 & 8.122 & 8.121 & 0.127 & 0.136 & b.129 \\
\hline $1.67 \mathrm{E}+65$ & 0.129 & 6.135 & 0.133 & 6.118 & 0.118 & 8.119 & 8.118 & 8.128 & 0.124 & 0.131 & 0.122 \\
\hline $1.96 E+65$ & 0.121 & 6.131 & c.125 & 8.118 & 8.115 & 8.111 & 8.112 & 8.113 & 0.119 & 0.123 & 6.116 \\
\hline $3.67 E+65$ & 0.118 & 0.128 & B. 121 & 8.187 & 8.111 & 8.189 & 8.111 & 8.112 & 0.114 & 0.118 & 0.111 \\
\hline $7.11 E+65$ & 0.115 & 6.123 & 6.115 & 8.186 & 8.187 & 8.188 & 8.186 & 8.189 & 6.111 & 6.112 & 6.165 \\
\hline $1.65 \mathrm{E}+66$ & 6.114 & 0.121 & 6.113 & 8.182 & 8.182 & 8.184 & 8.184 & 8.183 & 0.107 & 0.111 & 0.106 \\
\hline
\end{tabular}

TABLE A.3. Hydraulic Conductivity Data from the BWIF Southeast Caisson

Hydraulic Conductivity, cm/s, at Depth, cm

\begin{tabular}{|c|c|c|c|c|c|c|c|c|c|c|c|}
\hline Time, $\mathbf{s}$ & 45 & 60 & 75 & 96 & 165 & 120 & 135 & 150 & 180 & 216 & 240 \\
\hline $84 E+62$ & $7.46 \mathrm{E}-64$ & & & & & & & & & & \\
\hline 93 & 7.81E-64 & & & $83 E-63$ & $16 \mathrm{E}-63$ & & $.75 E-63$ & & & & \\
\hline+63 & $.61 E-64$ & $.63 E-63$ & $.32 E-63$ & $.67 E-63$ & $1.83 \mathrm{E}-63$ & $2.69 \mathrm{E}-63$ & $.33 E-63$ & $56 E-63$ & $.62 E-63$ & & $3.75 \mathrm{E}-83$ \\
\hline 63 & $5.34 E-64$ & $.42 \mathrm{E}-64$ & $.69 \mathrm{E}-63$ & $.29 E-63$ & $1.59 \mathrm{E}-63$ & $1.71 E-63$ & $.91 E-63$ & $11 E-63$ & $.51 E-63$ & & $3.21 E-63$ \\
\hline 2.88 & 4.33E- 64 & $6.89 E-64$ & $.61 E-94$ & $.67 E-63$ & $24 E-63$ & 41E-93 & $1.58 E-63$ & $.74 E-93$ & $.69 E-63$ & $.43 \mathrm{E}-63$ & 63 \\
\hline & $.55 E-64$ & $.69 E-64$ & $.49 E-64$ & $7 E-64$ & $E-63$ & $7 E-63$ & $31 E-63$ & $45 \mathrm{E}-63$ & -63 & $.66 \mathrm{E}-63$ & \\
\hline+63 & $2.71 E-64$ & $1.38 E-64$ & $5.81 E-64$ & $.96 \mathrm{E}-64$ & $7.99 \mathrm{E}-64$ & $9.12 E-64$ & $1.62 E-63$ & $.14 E-63$ & $.38 E-63$ & $.64 E-63$ & $1.89 E-63$ \\
\hline 7.08 & $1.44 E-84$ & 2.35E-64 & $.17 E-64$ & $.80 E-64$ & $.41 E-64$ & $5.65 \mathrm{E}-64$ & $5.76 E-64$ & $6.36 \mathrm{E}-84$ & $7.80 \mathrm{E}-64$ & $9.46 \mathrm{E}-64$ & $1.11 \mathrm{E}$ \\
\hline 93 & $.64 E-64$ & $.71 E-64$ & $2.31 E-64$ & $79 E-94$ & $24 E-64$ & $73 E-64$ & $1.21 E-64$ & $.71 E-64$ & $.86 E-64$ & $.63 \mathrm{E}-64$ & 8.32E- 84 \\
\hline 1.43 & & & $6 \mathrm{E}-64$ & & & $92 E-64$ & $8 E-64$ & $.44 E-84$ & $3.02 E-64$ & $3.68 E-64$ & \\
\hline $1.79 \mathrm{E}$ & $3.66 \mathrm{E}-65$ & 6.60E-65 & 8.29E-65 & $.02 E-64$ & $1.20 \mathrm{E}-64$ & $1.39 E-64$ & $1.58 \mathrm{E}-64$ & $1.77 E-64$ & $.19 E-64$ & 2.67E-64 & $3.19 \mathrm{E}-64$ \\
\hline $2.22 \mathrm{E}$ & $2.63 \mathrm{E}-95$ & 4.29E- 65 & $5.97 E-65$ & $7.42 E-65$ & 8.75E- 65 & $1.01 E-64$ & $1.16 \mathrm{E}-04$ & $1.39 \mathrm{E}-64$ & $1.61 E-64$ & $1.96 \mathrm{E}-64$ & $2.34 E-04$ \\
\hline+64 & $1.99 \mathrm{E}-65$ & $3.26 E-65$ & 4.55E- 95 & $5.69 E-95$ & $6.74 E-95$ & $7.82 E-65$ & 8. $92 E-95$ & $1.00 \mathrm{E}-04$ & $1.24 E-64$ & $1.51 E-64$ & $1.80 \mathrm{E}-04$ \\
\hline 8.16 & $3.44 \mathrm{E}-66$ & 5.57E-66 & B. $66 \mathrm{E}-66$ & $1.65 \mathrm{E}-65$ & 1.27E-65 & $1.49 \mathrm{E}-65$ & $1.71 E-95$ & $1.93 \mathrm{E}-65$ & $2.38 E-65$ & $2.87 E-65$ & $3.38 E-85$ \\
\hline 1.07 & $2.23 E-66$ & $3.61 E-66$ & $5.28 E-66$ & $6.97 \mathrm{E}-66$ & $8.46 E-86$ & $9.95 E-66$ & $1.14 E-65$ & $1.29 E-65$ & $1.59 \mathrm{E}-65$ & $1.91 \mathrm{E}-65$ & $2.24 \mathrm{E}-85$ \\
\hline $1.96 \mathrm{E}+95$ & $8.64 E-87$ & 1. $39 \mathrm{E}-96$ & $2.68 \mathrm{E}-66$ & 2.82E-66 & $3.46 E-66$ & 4. $.99 \mathrm{E}-66$ & $4.71 E-96$ & 5. $32 E-66$ & $6.54 E-66$ & $7.79 \mathrm{E}-106$ & $9.69 \mathrm{E}-66$ \\
\hline 3.67 & 3.22E-67 & 5.16E-67 & $7.91 E-67$ & $1.16 \mathrm{E}-66$ & 1.37E-66 & $1.62 \mathrm{E}-66$ & 1. $87 E-96$ & $2.12 E-66$ & $2.66 \mathrm{E}-66$ & $3.67 \mathrm{E}-66$ & 3. $55 \mathrm{E}-66$ \\
\hline $7.11 E+85$ & $1.14 \mathrm{E}-67$ & 1. B1E- 97 & 2.86E-67 & 4.12E-67 & 5.17E-97 & 6.17E-67 & $7.12 \mathrm{E}-97$ & B. $66 E-67$ & $9.83 E-67$ & $1.15 E-66$ & $1.32 E-86$ \\
\hline $1.65 \mathrm{E}+96$ & $6.11 E-98$ & $9.73 E-98$ & 1.67E-67 & $2.36 E-67$ & $2.96 E-67$ & $3.47 E-67$ & $4.61 E-97$ & 4.54E-67 & $5.52 E-67$ & $6,45 \mathrm{E}-67$ & 7.35E- 97 \\
\hline
\end{tabular}


TABLE A.4. Water Content Data from the BWIF North Caisson

Water Content, $\mathrm{cm}^{3} / \mathrm{cm}^{3}$, at Depth, om

\begin{tabular}{|c|c|c|c|c|c|c|c|c|c|}
\hline me, $s$ & 30 & 45 & 60 & 90 & 120 & 150 & 180 & 210 & 240 \\
\hline & & & & .297 & & 307 & .300 & 0.295 & .2 \\
\hline & & & & .298 & & & & & \\
\hline & & & & ).222 & 2 & & & & \\
\hline & & 0.1 & & 0.199 & 0.2 & & & & \\
\hline & & & & 0.188 & & & & & \\
\hline & 0.1 & 0.1 & & 0.179 & & & & 0.2 & \\
\hline & & & & & & & & & \\
\hline & 0 & & & & & & & & \\
\hline & & & & & & & & & \\
\hline & & 0.1 & & 0.1 & & & & & \\
\hline & & & & & & & & & \\
\hline & & & & & & & & & \\
\hline & & & & & & & & & \\
\hline & & 0.1 & & & & & & & \\
\hline & & & & & & & & & \\
\hline & & & & & & & & & \\
\hline & & 0.0 & & & & 0.10 & 0.1 & & \\
\hline
\end{tabular}

TABLE A.5. Matric Head Data for the BWIF North Caisson

Matric Head, $\mathrm{cm}$, at Depth, om

\begin{tabular}{|c|c|c|c|c|c|c|c|c|}
\hline Time, $\mathbf{s}$ & 15 & 30 & 45 & 60 & $\underline{90}$ & 120 & 150 & 180 \\
\hline $\begin{array}{l}0.00 \mathrm{E}+00 \\
4.80 \mathrm{E}+02 \\
8.40 \mathrm{E}+02 \\
1.38 \mathrm{E}+03 \\
2.04 \mathrm{E}+03 \\
2.88 \mathrm{E}+03 \\
4.68 \mathrm{E}+03 \\
6.48 \mathrm{E}+03 \\
8.28 \mathrm{E}+03 \\
1.43 \mathrm{E}+04 \\
2.03 \mathrm{E}+04 \\
2.75 \mathrm{E}+04 \\
8.93 \mathrm{E}+04 \\
1.88 \mathrm{E}+05 \\
2.75 \mathrm{E}+05 \\
6.23 \mathrm{E}+05 \\
1.15 \mathrm{E}+06\end{array}$ & $\begin{array}{l}7 \\
-19 \\
-20 \\
-20 \\
-21 \\
-22 \\
-25 \\
-26 \\
-26 \\
-36 \\
-34 \\
-41 \\
-44 \\
-48 \\
-42 \\
-42 \\
-41\end{array}$ & $\begin{array}{l}1 \\
-12 \\
-14 \\
-15 \\
-17 \\
-16 \\
-20 \\
-19 \\
-21 \\
-24 \\
-27 \\
-23 \\
-34 \\
-37 \\
-32 \\
-35 \\
-32\end{array}$ & $\begin{array}{l}2 \\
-13 \\
-13 \\
-13 \\
-15 \\
-14 \\
-15 \\
-16 \\
-17 \\
-22 \\
-24 \\
-20 \\
-30 \\
-31 \\
-26 \\
-32 \\
-24\end{array}$ & $\begin{array}{r}8 \\
-12 \\
-14 \\
-12 \\
-14 \\
-14 \\
-15 \\
-15 \\
-16 \\
-20 \\
-22 \\
-19 \\
-28 \\
-33 \\
-28 \\
-34 \\
-27\end{array}$ & $\begin{array}{l}12 \\
-12 \\
-13 \\
-13 \\
-14 \\
-12 \\
-14 \\
-12 \\
-14 \\
-17 \\
-20 \\
-18 \\
-24 \\
-29 \\
-26 \\
-31 \\
-33\end{array}$ & $\begin{array}{r}8 \\
-9 \\
-12 \\
-13 \\
-13 \\
-9 \\
-13 \\
-10 \\
-13 \\
-17 \\
-17 \\
-15 \\
-23 \\
-26 \\
-24 \\
-26 \\
-28\end{array}$ & $\begin{array}{l}10 \\
-2 \\
-7 \\
-14 \\
-14 \\
-15 \\
-15 \\
-14 \\
-16 \\
-20 \\
-24 \\
-21 \\
-28 \\
-34 \\
-32 \\
-35 \\
-38\end{array}$ & $\begin{array}{r}8 \\
-2 \\
-7 \\
-15 \\
-14 \\
-14 \\
-14 \\
-13 \\
-14 \\
-18 \\
-19 \\
-18 \\
-24 \\
-29 \\
-26 \\
-30 \\
-33\end{array}$ \\
\hline
\end{tabular}


TABLE A.6. Hydraulic Conductivity Data from the BWIF North Caisson Hydraulic Conductivity, $\mathrm{cm} / \mathrm{s}$, at Depth, ca

\begin{tabular}{|c|c|c|c|c|c|c|c|c|c|}
\hline Time, $\mathbf{s}$ & 30 & 45 & 60 & 90 & 120 & 150 & 180 & 210 & 240 \\
\hline $4.80 E+62$ & $1.72 E-63$ & 3.22E-63 & 4.89E-63 & $6.56 \mathrm{E}-63$ & 8.56E-63 & $6.56 E-63$ & $6.56 \mathrm{E}-63$ & $6.56 \mathrm{E}-63$ & 6.56E-63 \\
\hline $8.40 E+62$ & $9.17 E-64$ & $1.43 \mathrm{E}-63$ & $2.18 \mathrm{E}-63$ & $4.17 E-63$ & $1.69 \mathrm{E}-62$ & $1.83 E-62$ & $2.62 E-62$ & $2.62 E-62$ & $2.62 \mathrm{E}-62$ \\
\hline $1.38 E+63$ & $4.77 E-64$ & $7.47 \mathrm{E}-64$ & $1.66 \mathrm{E}-63$ & $1.85 \mathrm{E}-63$ & $2.71 E-63$ & $3.94 E-63$ & $7.18 \mathrm{E}-63$ & 1.63E-62 & $1.09 \mathrm{E}-62$ \\
\hline $2.64 E+63$ & $2.94 E-64$ & $4.56 \mathrm{E}-64$ & $6.19 \mathrm{E}-64$ & $1.08 \mathrm{E}-63$ & $1.58 \mathrm{E}-63$ & $2.13 E-63$ & $2.95 \mathrm{E}-63$ & $4.24 E-63$ & B. $81 E-63$ \\
\hline $2.88 E+63$ & $1.85 E-64$ & $2.92 \mathrm{E}-64$ & $3.88 E-64$ & 6.79E-64 & $9.92 E-64$ & $1.33 \mathrm{E}-63$ & $1.70 \mathrm{E}-63$ & $2.68 \mathrm{E}-63$ & 2.58E-63 \\
\hline $4.68 E+63$ & $9.86 \mathrm{E}-65$ & $1.65 \mathrm{E}-64$ & 2.62E-64 & $3.53 \mathrm{E}-64$ & $5.16 E-64$ & $6.92 E-64$ & $8.81 E-64$ & $1.68 \mathrm{E}-63$ & $1.28 \mathrm{E}-63$ \\
\hline $6.48 E+63$ & $6.48 \mathrm{E}-65$ & $1.01 E-64$ & $1.31 E-64$ & $2.28 \mathrm{E}-04$ & $3.33 E-64$ & $4.47 E-64$ & $5.69 E-64$ & $6.98 \mathrm{E}-64$ & B. $34 E-64$ \\
\hline $8.28 E+63$ & $4.86 \mathrm{E}-65$ & $7.31 E-65$ & 9.37E-65 & $1.63 \mathrm{E}-64$ & $2.39 E-64$ & $3.26 E-64$ & 4.07E-64 & $5.61 E-64$ & $5.99 \mathrm{E}-64$ \\
\hline $1.43 E+64$ & $2.46 \mathrm{E}-65$ & $3.56 \mathrm{E}-65$ & 4.47E-65 & $7.79 E-65$ & $1.14 E-64$ & $1.52 E-64$ & $1.94 \mathrm{E}-04$ & $2.38 E-64$ & 2.86E-04 \\
\hline $2.63 E+64$ & $2.61 E-65$ & $2.14 E-85$ & 2.77E-65 & $4.83 E-65$ & $7.06 \mathrm{E}-05$ & $9.43 E-65$ & 1.20E-64 & $1.48 E-64$ & $1.78 E-64$ \\
\hline $2.75 E+64$ & $1.36 \mathrm{E}-65$ & $1.39 E-65$ & $1.84 E-65$ & $3.26 \mathrm{E}-65$ & $4.68 E-65$ & $6.24 E-65$ & $7.95 E-65$ & $9.79 \mathrm{E}-65$ & $1.18 \mathrm{E}-64$ \\
\hline $8.93 E+64$ & $2.75 \mathrm{E}-66$ & $2.58 E-66$ & $3.71 E-66$ & $6.46 \mathrm{E}-68$ & $9.46 \mathrm{E}-66$ & $1.26 \mathrm{E}-65$ & $1.60 \mathrm{E}-05$ & $1.98 \mathrm{E}-65$ & $2.40 \mathrm{E}-05$ \\
\hline $1.88 E+65$ & $1.69 \mathrm{E}-66$ & $9.77 \mathrm{E}-07$ & 1.33E- 96 & $2.30 \mathrm{E}-66$ & $3.37 E-66$ & 4. $48 \mathrm{E}-66$ & $5.71 E-86$ & $7.06 \mathrm{E}-66$ & 8. $66 E-66$ \\
\hline $2.75 E+65$ & $6.85 E-67$ & $5.98 E-67$ & $7.83 E-67$ & $1.36 \mathrm{E}-66$ & $1.99 E-66$ & $2.64 E-66$ & 3.37E-66 & 4.17E-66 & $5.69 \mathrm{E}-66$ \\
\hline $6.23 E+65$ & 2.50E-07 & 2.68E- 67 & 2. 52E-67 & 4.38E-67 & $6.41 E-67$ & B. 56E-07 & $1.68 E-66$ & $1.34 \mathrm{E}-68$ & $1.65 E-66$ \\
\hline $1.15 E+66$ & 1.17E-67 & $9.20 E-68$ & 1.67E-67 & $1.86 \mathrm{E}-67$ & $2.73 E-67$ & $3.61 E-67$ & 4.61E-67 & $5.71 E-67$ & $7.66 \mathrm{E}-67$ \\
\hline
\end{tabular}

TABLE A.7. Water Content Data from the Grass Site

Water Content, $\mathrm{cm}^{3} / \mathrm{cm}^{3}$, at Depth, om

\begin{tabular}{|c|c|c|c|c|c|c|c|c|}
\hline Time, $s$ & 15 & 30 & 45 & 60 & 90 & 120 & 150 & 180 \\
\hline $0.00 \mathrm{E}+00$ & 0.218 & 0.191 & 0.146 & 0.132 & 0.132 & 0.128 & 0.130 & 0.142 \\
\hline $4.84 E+02$ & & & 0.144 & & & 0.131 & 0.128 & 0.141 \\
\hline $1.08 \mathrm{E}+03$ & 0.213 & 0.177 & 0.140 & 0.121 & 0.125 & & & 0.143 \\
\hline $1.68 \mathrm{E}+03$ & 0.204 & 0.173 & 0.133 & 0.116 & 0.122 & 0.117 & 0.124 & 0.136 \\
\hline $2.88 \mathrm{E}+$ & 0.203 & 0.170 & 0.124 & 0.108 & 0.114 & 0.121 & 0.121 & 0.132 \\
\hline $4.08 \mathrm{E}+03$ & 0.205 & 0.161 & 0.118 & 0.105 & 0.112 & & & 0.129 \\
\hline $5.28 \mathrm{E}+03$ & 0.207 & 0.159 & 0.116 & 0.102 & 0.105 & 0.106 & 0.111 & 0.123 \\
\hline $7.08 \mathrm{E}+03$ & 0.204 & 0.161 & 0.109 & 0.094 & 0.099 & & 0.103 & 0.116 \\
\hline & 0.209 & 0.158 & 0.110 & 0.089 & 0.100 & 0.094 & 0.101 & 0.112 \\
\hline $1.31 \mathrm{E}+04$ & 0.201 & 0.160 & 0.105 & 0.0 & 0.091 & 0.087 & 0.091 & \\
\hline $1.67 \mathrm{E}+04$ & 0.201 & 0.154 & 0.104 & 0.087 & 0.086 & 0.085 & 0.083 & 0.096 \\
\hline $1.97 E+04$ & 0.205 & 0.154 & 0.101 & 0.087 & 0.083 & & 0.086 & 0.090 \\
\hline $6.89 \mathrm{E}+04$ & 0.21 & 0.146 & 0.094 & 0.079 & 0.077 & 0.072 & 0.073 & 0.074 \\
\hline $9.93 E+04$ & 0.19 & 0.147 & 0.095 & 0.076 & 0.073 & 0.070 & 0.070 & 0.070 \\
\hline $1.87 E+05$ & & 0.138 & 0.083 & 0.069 & 0.070 & 0.1 & 0. & 0.066 \\
\hline $4.27 E+05$ & 0.1 & 0.128 & 0.074 & 0.061 & 0.066 & 0.065 & 0.060 & 0.061 \\
\hline $6.18 \mathrm{E}+05$ & & 0.12 & 0.072 & 0.057 & 0.066 & & & 0.059 \\
\hline $7.67 E+05$ & & 0.118 & 0.070 & 0.059 & 0.0 & 0.057 & 0.057 & 0.058 \\
\hline & & & 0.0 & 0.0 & & & & 0.056 \\
\hline & 0.1 & 0.1 & 0.068 & 0.0 & 0.0 & 0.05 & 0.05 & 0.054 \\
\hline & & 0.108 & 0.065 & 0.052 & 0.055 & 0.052 & 0.048 & 0.052 \\
\hline
\end{tabular}


TABLE A.8. Matric Head Data from the Grass Site

Matric Head, cm, at Depth, om

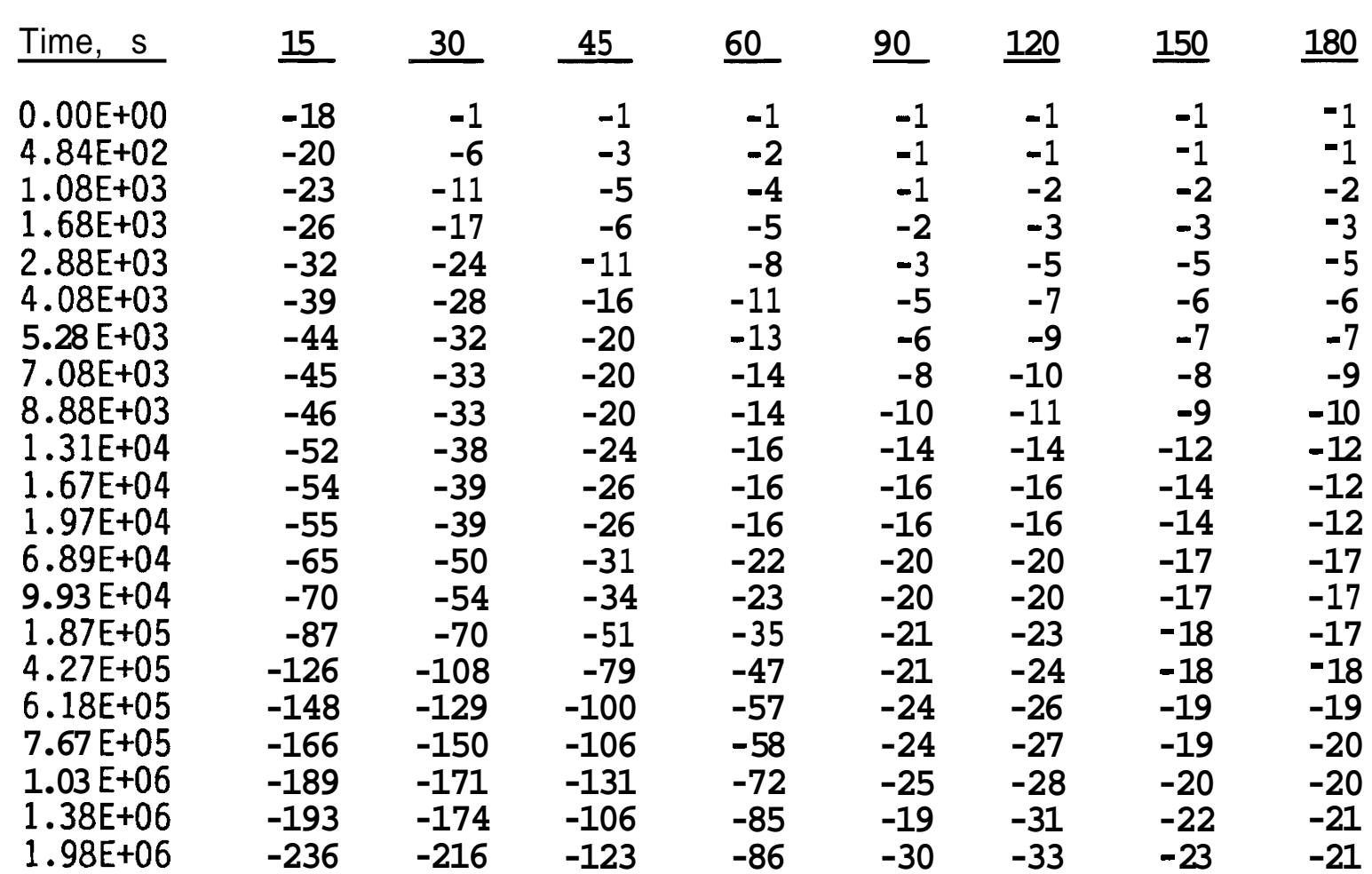

TABLE A.9. Water Content Data from the McGee Ranch Site

Water Content, $\mathrm{cm}^{3} / \mathrm{cm}^{3}$, at Depth, om

\begin{tabular}{|c|c|c|c|c|c|}
\hline Time, $s$ & 15 & 30 & 45 & 60 & 90 \\
\hline $\begin{array}{l}0.00 \mathrm{E}+00 \\
5.96 \mathrm{E}+02 \\
1.50 \mathrm{E}+03 \\
2.70 \mathrm{E}+03 \\
4.20 \mathrm{E}+03 \\
6.30 \mathrm{E}+03 \\
9.90 \mathrm{E}+03 \\
5.97 \mathrm{E}+04 \\
8.07 \mathrm{E}+04 \\
3.23 \mathrm{E}+05 \\
6.67 \mathrm{E}+05\end{array}$ & $\begin{array}{l}0.397 \\
0.381 \\
0.374 \\
0.364 \\
0.357 \\
0.342 \\
0.327 \\
0.250 \\
0.237 \\
0.186 \\
0.163 \\
0.153\end{array}$ & $\begin{array}{l}0.413 \\
0.405 \\
0.398 \\
0.395 \\
0.386 \\
0.375 \\
0.365 \\
0.266 \\
0.253 \\
0.197 \\
0.176 \\
0.158\end{array}$ & $\begin{array}{l}0.399 \\
0.397 \\
0.393 \\
0.385 \\
0.386 \\
0.379 \\
0.373 \\
0.302 \\
0.286 \\
0.224 \\
0.196 \\
0.176\end{array}$ & $\begin{array}{l}0.395 \\
0.394 \\
0.387 \\
0.386 \\
0.388 \\
0.381 \\
0.375 \\
0.313 \\
0.298 \\
0.231 \\
0.204 \\
0.183\end{array}$ & $\begin{array}{l}0.391 \\
0.389 \\
0.389 \\
0.386 \\
0.385 \\
0.383 \\
0.381 \\
0.343 \\
0.324 \\
0.226 \\
0.186 \\
0.157\end{array}$ \\
\hline
\end{tabular}


TABLE A.9. (contd)

Time-Averaged Water Content, $\mathrm{cm}^{3} / \mathrm{cm}^{3}$, at Depth, om

\begin{tabular}{|c|c|c|c|c|c|}
\hline Time, s & 15 & 30 & 45 & 60 & 90 \\
\hline $\begin{array}{l}2.59 \mathrm{E}+02 \\
1.04 \mathrm{E}+03 \\
2.07 \mathrm{E}+03 \\
3.46 \mathrm{E}+03 \\
5.27 \mathrm{E}+03 \\
8.12 \mathrm{E}+03 \\
3.48 \mathrm{E}+04 \\
7.02 \mathrm{E}+04 \\
2.02 \mathrm{E}+05 \\
4.95 \mathrm{E}+05 \\
9.70 \mathrm{E}+05\end{array}$ & $\begin{array}{l}0.389 \\
0.378 \\
0.369 \\
0.360 \\
0.350 \\
0.335 \\
0.289 \\
0.243 \\
0.211 \\
0.174 \\
0.158\end{array}$ & $\begin{array}{l}0.409 \\
0.402 \\
0.397 \\
0.390 \\
0.381 \\
0.370 \\
0.315 \\
0.259 \\
0.225 \\
0.186 \\
0.167\end{array}$ & $\begin{array}{l}0.398 \\
0.395 \\
0.389 \\
0.386 \\
0.382 \\
0.376 \\
0.338 \\
0.294 \\
0.255 \\
0.210 \\
0.186\end{array}$ & $\begin{array}{l}0.394 \\
0.390 \\
0.386 \\
0.387 \\
0.384 \\
0.378 \\
0.344 \\
0.305 \\
0.264 \\
0.217 \\
0.193\end{array}$ & $\begin{array}{l}0.390 \\
0.389 \\
0.388 \\
0.386 \\
0.384 \\
0.382 \\
0.362 \\
0.334 \\
0.275 \\
0.206 \\
0.172\end{array}$ \\
\hline
\end{tabular}

TABLE A.IO. Matric Head Data from the McGee Ranch Site Matric Head, cm, at Depth, om

\begin{tabular}{|c|c|c|c|c|c|}
\hline Time, $s$ & 15 & 30 & 45 & 60 & 90 \\
\hline $\begin{array}{l}0.00 E+00 \\
5.96 E+02 \\
1.50 E+03 \\
2.70 E+03 \\
4.20 E+03 \\
6.30 E+03 \\
9.90 E+03 \\
5.97 E+04 \\
8.07 E+04 \\
3.23 E+05 \\
6.67 E+05\end{array}$ & $\begin{array}{l}-29 \\
-38 \\
-53 \\
-72 \\
-89 \\
-98 \\
-110 \\
-154 \\
-167 \\
-236 \\
-286 \\
-340\end{array}$ & $\begin{array}{l}-30 \\
-39 \\
-53 \\
-71 \\
-87 \\
-96 \\
-107 \\
-152 \\
-164 \\
-231 \\
-278 \\
-327\end{array}$ & $\begin{array}{l}-37 \\
-44 \\
-56 \\
-72 \\
-87 \\
-97 \\
-107 \\
-154 \\
-165 \\
-229 \\
-271 \\
-327\end{array}$ & $\begin{array}{l}-42 \\
-49 \\
-58 \\
-71 \\
-83 \\
-91 \\
-100 \\
-143 \\
-153 \\
-217 \\
-269 \\
-323\end{array}$ & $\begin{array}{l}-43 \\
-48 \\
-56 \\
-67 \\
-77 \\
-84 \\
-91 \\
-131 \\
-144 \\
-212 \\
-268 \\
-326\end{array}$ \\
\hline
\end{tabular}

Time-Averaged Matric Head Data, cm, at Depth, cm

\begin{tabular}{|c|c|c|c|c|}
\hline $\begin{array}{l}\text { Time, } \mathrm{s} \\
2.59 \mathrm{E}+02 \\
1.04 \mathrm{E}+03 \\
2.07 \mathrm{E}+03 \\
3.46 \mathrm{E}+03 \\
5.27 \mathrm{E}+03 \\
8.12 \mathrm{E}+03 \\
3.48 \mathrm{E}+04 \\
7.02 \mathrm{E}+04 \\
2.02 \mathrm{E}+05 \\
4.95 \mathrm{E}+05 \\
9.70 \mathrm{E}+05\end{array}$ & $\begin{array}{l}15 \\
-34 \\
-46 \\
-63 \\
-81 \\
-94 \\
-104 \\
-132 \\
-161 \\
-202 \\
-261 \\
-313\end{array}$ & $\begin{array}{l}30 \\
-35 \\
-46 \\
-62 \\
-79 \\
-92 \\
-102 \\
-130 \\
-158 \\
-198 \\
-255 \\
-303\end{array}$ & $\begin{array}{l}45 \\
-41 \\
-50 \\
-64 \\
-80 \\
-92 \\
-102 \\
-131 \\
-160 \\
-197 \\
-250 \\
-299\end{array}$ & $\begin{array}{l}60 \\
-46 \\
-54 \\
-65 \\
-77 \\
-87 \\
-96 \\
-122 \\
-148 \\
-185 \\
-243 \\
-296\end{array}$ \\
\hline
\end{tabular}


TABLE A.II. Hydraulic Conductivity Data from the McGee Ranch Site Hydraulic Conductivity, $\mathrm{cm} / \mathrm{s}$, at Depth, cm

\begin{tabular}{|c|c|c|c|c|c|}
\hline $1 e, s$ & 15 & 30 & 45 & 60 & 90 \\
\hline $\begin{array}{l}2.59 \mathrm{E}+02 \\
1.04 \mathrm{E}+03 \\
2.07 \mathrm{E}+03 \\
3.46 \mathrm{E}+03 \\
5.27 \mathrm{E}+03 \\
3.12 \mathrm{E}+03 \\
3.48 \mathrm{E}+04 \\
7.02 \mathrm{E}+04\end{array}$ & $\begin{array}{l}3.63 \mathrm{E}-04 \\
1.10 \mathrm{E}-04 \\
1.36 \mathrm{E}-04 \\
7.58 \mathrm{E}-05 \\
1.24 \mathrm{E}-04 \\
7.29 \mathrm{E}-05 \\
2.79 \mathrm{E}-05 \\
1.13 \mathrm{E}-05 \\
4.33 \mathrm{E}-06 \\
1.70 \mathrm{E}-06 \\
8.51 \mathrm{E}-07\end{array}$ & $\begin{array}{l}1.9 \\
2.0 \\
1.5 \\
2.1 \\
1.2 \\
5.2 \\
1.9 \\
7.6 \\
3.0\end{array}$ & & $\begin{array}{l}7.64 \mathrm{E}-04 \\
3.76 \mathrm{E}-04 \\
3.78 \mathrm{E}-04 \\
1.97 \mathrm{E}-04 \\
4.29 \mathrm{E}-04 \\
2.50 \mathrm{E}-04 \\
1.69 \mathrm{E}-04 \\
7.80 \mathrm{E}-05 \\
2.45 \mathrm{E}-05 \\
5.36 \mathrm{E}-06 \\
1.67 \mathrm{E}-06\end{array}$ & \\
\hline
\end{tabular}


APPENDIX B

PARTICLE-SIZE DATA 


\section{APPENDIX B}

\section{PARTICLE-SIZE DATA}

TABLE B.1. Particle-Size Distribution Data for Samples from the BWTF Site. Where discrepencies were found in the particle-size distribution, data were interpolated to obtain smooth curves.

\begin{tabular}{|c|c|c|c|c|c|}
\hline Sample ID & $\begin{array}{l}\text { Particle Size } \\
\text { (microns) }\end{array}$ & $\%$ Less Than & Sample ID & $\begin{array}{l}\text { Particle Size } \\
\text { (microns) }\end{array}$ & $\%$ Less Than \\
\hline $\begin{array}{c}\text { BWTF-15A } \\
96 \% \text { Sand } \\
3 \% \text { S i I t } \\
1 \% \text { Clay }\end{array}$ & $\begin{array}{l}2.0 \mathrm{E}+3 \\
1.0 \mathrm{E}+3 \\
5.0 \mathrm{E}+2 \\
2.5 \mathrm{E}+2 \\
1.1 \mathrm{E}+2 \\
7.5 \mathrm{E}+1 \\
5.3 \mathrm{E}+1 \\
5.1 \mathrm{E}+1 \\
3.0 \mathrm{E}+1 \\
1.6 \mathrm{E}+1 \\
9.4 \mathrm{E}+0 \\
6.6 \mathrm{E}+0 \\
5 \cdot 4 \mathrm{E}+0 \\
4.7 \mathrm{E}+0 \\
1.4 \mathrm{E}+0\end{array}$ & $\begin{array}{r}98.0 \\
88.6 \\
36.2 \\
9.5 \\
5.0 \\
4.0 \\
3.5 \\
3.8 \\
3.4 \\
3.1 \\
2.3 \\
1.3 \\
1.3 \\
1.1 \\
1.1\end{array}$ & $\begin{array}{c}\text { BWTF-15B } \\
96 \% \text { Sand } \\
3 \% \text { S il t } \\
1 \% \text { Clay }\end{array}$ & $\begin{array}{l}2.0 \mathrm{E}+3 \\
1.0 \mathrm{E}+3 \\
5.0 \mathrm{E}+2 \\
2.5 \mathrm{E}+2 \\
1.1 \mathrm{E}+2 \\
7.5 \mathrm{E}+1 \\
5.3 \mathrm{E}+1 \\
5.1 \mathrm{E}+1 \\
3.0 \mathrm{E}+1 \\
1.6 \mathrm{E}+1 \\
9.5 \mathrm{E}+0 \\
6.6 \mathrm{E}+0 \\
5.4 \mathrm{E}+0 \\
4.7 \mathrm{E}+0 \\
1.4 \mathrm{E}+0\end{array}$ & $\begin{array}{r}97.7 \\
85.2 \\
29.7 \\
8.4 \\
4.6 \\
3.9 \\
3.5 \\
3.8 \\
3.5 \\
3.3 \\
1.5 \\
1.3 \\
1.1 \\
1.1 \\
1.1\end{array}$ \\
\hline $\begin{array}{r}\text { BWTF-16A } \\
97 \% \text { Sand } \\
2 \% \text { S i I t } \\
1 \% \text { Clay }\end{array}$ & $\begin{array}{l}2.0 E+3 \\
1.0 E+3 \\
5 \cdot 0 E+2 \\
2.5 E+2 \\
1.1 E+2 \\
7 \cdot 5 E+1 \\
5.3 E+1 \\
5 \cdot 1 E+1 \\
3 \cdot 0 E+1 \\
1.6 E+1 \\
9.4 E+0 \\
6 \cdot 6 E+0 \\
5 \cdot 4 E+0 \\
4 \cdot 7 E+0 \\
1 \cdot 4 E+0\end{array}$ & $\begin{array}{r}96.7 \\
86.2 \\
42.2 \\
11.1 \\
5.2 \\
3.8 \\
3.2 \\
3.6 \\
3.6 \\
3.1 \\
1.9 \\
1.3 \\
1.3 \\
1.3 \\
1.0\end{array}$ & $\begin{array}{r}\text { BWTF-16B } \\
96 \% \text { Sand } \\
3 \% \text { S il t } \\
1 \% \text { Clay }\end{array}$ & $\begin{array}{l}2.0 \mathrm{E}+3 \\
1.0 \mathrm{E}+3 \\
5.0 \mathrm{E}+2 \\
2.5 \mathrm{E}+2 \\
1.1 \mathrm{E}+2 \\
7.5 \mathrm{E}+1 \\
5.3 \mathrm{E}+1 \\
5.1 \mathrm{E}+1 \\
3.0 \mathrm{E}+1 \\
1.6 \mathrm{E}+1 \\
9.5 \mathrm{E}+0 \\
6.6 \mathrm{E}+0 \\
5.4 \mathrm{E}+0 \\
4.7 \mathrm{E}+0 \\
1.4 \mathrm{E}+0\end{array}$ & $\begin{array}{r}98.6 \\
88.4 \\
37.2 \\
10.9 \\
5.4 \\
4.2 \\
3.6 \\
3.8 \\
3.8 \\
2.8 \\
1.5 \\
1.3 \\
1.1 \\
0.8 \\
0.8\end{array}$ \\
\hline
\end{tabular}


TABLE B.1. (contd)

\begin{tabular}{|c|c|c|c|c|c|}
\hline Sample ID & $\begin{array}{c}\text { Particle Size } \\
\text { (microns) }\end{array}$ & $\%$ Less Than & Sample ID & $\begin{array}{c}\text { Particle Size } \\
\text { (microns) }\end{array}$ & $\%$ Less Than \\
\hline $\begin{array}{c}\text { BWTF-17A } \\
98 \% \text { Sand } \\
1 \% \text { Silt } \\
1 \% \text { Clay }\end{array}$ & $\begin{array}{l}2.0 \mathrm{E}+3 \\
1.0 \mathrm{E}+3 \\
5.0 \mathrm{E}+2 \\
2.5 \mathrm{E}+2 \\
1.1 \mathrm{E}+2 \\
7.5 \mathrm{E}+1 \\
5.3 \mathrm{E}+1 \\
5.1 \mathrm{E}+1 \\
2.9 \mathrm{E}+1 \\
1.6 \mathrm{E}+1 \\
9.4 \mathrm{E}+0 \\
6.6 \mathrm{E}+0 \\
5.4 \mathrm{E}+0 \\
4.7 \mathrm{E}+0 \\
1.4 \mathrm{E}+0\end{array}$ & $\begin{array}{c}98.0 \\
89.0 \\
37.6 \\
12.0 \\
2.8 \\
1.4 \\
0.7 \\
4.4 \\
4.1 \\
2.8 \\
2.5 \\
1.9 \\
1.8 \\
1.4 \\
1.0\end{array}$ & $\begin{array}{c}\text { BWTF-17B } \\
97 \% \text { Sand } \\
2 \% \text { Silt } \\
1 \% \text { Clay }\end{array}$ & $\begin{array}{l}2.0 \mathrm{E}+3 \\
1.0 \mathrm{E}+3 \\
5.0 \mathrm{E}+2 \\
2.5 \mathrm{E}+2 \\
1.1 \mathrm{E}+2 \\
7.5 \mathrm{E}+1 \\
5.3 \mathrm{E}+1 \\
5.1 \mathrm{E}+1 \\
3.0 \mathrm{E}+1 \\
1.6 \mathrm{E}+1 \\
9.4 \mathrm{E}+0 \\
6.6 \mathrm{E}+0 \\
5.4 \mathrm{E}+0 \\
4.7 \mathrm{E}+0 \\
1.4 \mathrm{E}+0\end{array}$ & $\begin{array}{r}96.8 \\
85.5 \\
32.8 \\
9.8 \\
5.2 \\
4.0 \\
3.3 \\
4.0 \\
3.4 \\
3.1 \\
2.5 \\
1.9 \\
1.5 \\
1.4 \\
1.0\end{array}$ \\
\hline $\begin{array}{c}\text { BWTF-18A } \\
96 \% \text { Sand } \\
3 \% \text { Silt } \\
1 \% \text { Clay }\end{array}$ & $\begin{array}{l}2.0 \mathrm{E}+3 \\
1.0 \mathrm{E}+3 \\
5.0 \mathrm{E}+2 \\
2.5 \mathrm{E}+2 \\
1.1 \mathrm{E}+2 \\
7.5 \mathrm{E}+1 \\
5.3 \mathrm{E}+1 \\
5.1 \mathrm{E}+1 \\
2.9 \mathrm{E}+1 \\
1.6 \mathrm{E}+1 \\
9.4 \mathrm{E}+0 \\
6.6 \mathrm{E}+0 \\
5.4 \mathrm{E}+0 \\
4.7 \mathrm{E}+0 \\
1.4 \mathrm{E}+0\end{array}$ & $\begin{array}{r}96.2 \\
84.3 \\
32.7 \\
9.3 \\
5.3 \\
4.3 \\
3.9 \\
3.1 \\
3.0 \\
2.5 \\
2.5 \\
1.9 \\
1.9 \\
1.3 \\
1.1\end{array}$ & $\begin{array}{c}\text { BWTF-18B } \\
95 \% \text { Sand } \\
3 \% \text { Silt } \\
2 \% \text { Clay }\end{array}$ & $\begin{array}{l}2.0 \mathrm{E}+3 \\
1.0 \mathrm{E}+3 \\
5.0 \mathrm{E}+2 \\
2.5 \mathrm{E}+2 \\
1.1 \mathrm{E}+2 \\
7.5 \mathrm{E}+1 \\
5.3 \mathrm{E}+1 \\
5.1 \mathrm{E}+1 \\
2.9 \mathrm{E}+1 \\
1.6 \mathrm{E}+1 \\
9.4 \mathrm{E}+0 \\
6.6 \mathrm{E}+0 \\
5.4 \mathrm{E}+0 \\
4.7 \mathrm{E}+0 \\
1.4 \mathrm{E}+0\end{array}$ & $\begin{array}{r}97.6 \\
87.0 \\
46.9 \\
11.7 \\
6.4 \\
5.3 \\
4.7 \\
4.0 \\
3.8 \\
3.5 \\
3.1 \\
2.5 \\
2.5 \\
2.0 \\
2.0\end{array}$ \\
\hline $\begin{array}{r}\text { BWTF-19B } \\
96 \% \text { Sand } \\
2 \% \text { Silt } \\
2 \% \text { C lay }\end{array}$ & $\begin{array}{l}2.0 \mathrm{E}+3 \\
1.0 \mathrm{E}+3 \\
5.0 \mathrm{E}+2 \\
2.5 \mathrm{E}+2 \\
1.1 \mathrm{E}+2 \\
7.5 \mathrm{E}+1 \\
5.3 \mathrm{E}+1 \\
5.1 \mathrm{E}+1 \\
2.9 \mathrm{E}+1 \\
1.6 \mathrm{E}+1 \\
9.4 \mathrm{E}+0 \\
6.6 \mathrm{E}+0 \\
5.4 \mathrm{E}+0 \\
4.7 \mathrm{E}+0 \\
1.4 \mathrm{E}+0\end{array}$ & $\begin{array}{r}96.9 \\
85.7 \\
39.8 \\
10.5 \\
5.8 \\
4.8 \\
4.3 \\
3.6 \\
3.4 \\
3.0 \\
2.8 \\
2.2 \\
2.2 \\
1.6 \\
1.6\end{array}$ & & & \\
\hline
\end{tabular}


TABLE B.2. Particle-Size Distribution Data from the Grass Site

\begin{tabular}{|c|c|c|c|c|c|}
\hline Sample ID & $\begin{array}{c}\text { Particle Size } \\
\text { (microns) } \\
\end{array}$ & $\%$ Less Than & Sample ID & $\begin{array}{l}\text { Particle Size } \\
\text { (mi crons) } \\
\end{array}$ & $\%$ Less Than \\
\hline $\begin{array}{l}\frac{\text { GS-6A }}{79 \% \text { Sand }} \\
18 \% \text { Si } 1 \text { t } \\
3 \% \text { Clay }\end{array}$ & $\begin{array}{l}2.0 \mathrm{E}+3 \\
1.0 \mathrm{E}+3 \\
5.0 \mathrm{E}+2 \\
2 \cdot 5 \mathrm{E}+2 \\
1.1 \mathrm{E}+2 \\
7.5 \mathrm{E}+1 \\
5.3 \mathrm{E}+1 \\
4 \cdot 9 \mathrm{E}+1 \\
2 \cdot 9 \mathrm{E}+1 \\
1.6 \mathrm{E}+1 \\
9 \cdot 2 \mathrm{E}+0 \\
6.5 \mathrm{E}+0 \\
5 \cdot 3 \mathrm{E}+0 \\
4 \cdot 6 \mathrm{E}+0 \\
1 \cdot 3 \mathrm{E}+0\end{array}$ & $\begin{array}{l}98.7 \\
95.7 \\
44.2 \\
33.2 \\
28.3 \\
24.9 \\
21.2 \\
17.5 \\
12.5 \\
10.0 \\
7.5 \\
6.5 \\
5.0 \\
4.0 \\
3.3\end{array}$ & $\begin{array}{c}\text { GS-6B } \\
91 \% \text { Sand } \\
7 \% \text { Silt } \\
2 \% \text { Clay }\end{array}$ & $\begin{array}{l}2.0 \mathrm{E}+3 \\
1.0 \mathrm{E}+3 \\
5.0 \mathrm{E}+2 \\
2.5 \mathrm{E}+2 \\
1.1 \mathrm{E}+2 \\
7.5 \mathrm{E}+1 \\
5.3 \mathrm{E}+1 \\
4 \cdot 9 \mathrm{E}+1 \\
2 \cdot 8 \mathrm{E}+1 \\
1.6 \mathrm{E}+1 \\
9.3 \mathrm{E}+0 \\
6.6 \mathrm{E}+0 \\
5.4 \mathrm{E}+0 \\
4 \cdot 6 \mathrm{E}+0 \\
1 \cdot 3 \mathrm{E}+0\end{array}$ & $\begin{array}{r}99.7 \\
97.7 \\
25.2 \\
13.1 \\
11.1 \\
10.2 \\
9.2 \\
20.0 \\
19.8 \\
18.0 \\
5.0 \\
4.3 \\
3.3 \\
3.0 \\
2.0\end{array}$ \\
\hline $\begin{array}{l}\text { GS-7A } \\
73 \% \text { Sand } \\
23 \% \text { Silt } \\
4 \% \text { Clay }\end{array}$ & $\begin{array}{l}2.0 E+3 \\
1.0 E+3 \\
5.0 E+2 \\
2.5 E+2 \\
1.1 E+2 \\
7.5 E+1 \\
5.3 E+1 \\
4.9 E+1 \\
2.9 E+1 \\
1.6 E+1 \\
9.3 E+0 \\
6.5 E+0 \\
5.3 E+0 \\
4.6 E+0 \\
1.4 E+0\end{array}$ & $\begin{array}{l}99.1 \\
95.1 \\
61.7 \\
42.0 \\
35.8 \\
31.3 \\
26.9 \\
21.0 \\
14.8 \\
10.0 \\
7.5 \\
5.8 \\
5.0 \\
4.8 \\
3.8\end{array}$ & $\begin{array}{c}\frac{\text { GS-7B }}{92 \% \text { Sand }} \\
5 \% \text { Silt } \\
3 \% \text { Clay }\end{array}$ & $\begin{array}{l}2.0 \mathrm{E}+3 \\
1.0 \mathrm{E}+3 \\
5.0 \mathrm{E}+2 \\
2 \cdot 5 \mathrm{E}+2 \\
1.1 \mathrm{E}+2 \\
7 \cdot 5 \mathrm{E}+1 \\
5.3 \mathrm{E}+1 \\
5.0 \mathrm{E}+1 \\
2 \cdot 9 \mathrm{E}+1 \\
1.6 \mathrm{E}+1 \\
9.3 \mathrm{E}+0 \\
6.5 \mathrm{E}+0 \\
5 \cdot 4 \mathrm{E}+0 \\
4 \cdot 6 \mathrm{E}+0 \\
1.4 \mathrm{E}+0\end{array}$ & $\begin{array}{r}99.0 \\
90.3 \\
44.8 \\
13.8 \\
10.4 \\
9.1 \\
8.2 \\
6.5 \\
5.8 \\
5.0 \\
3.5 \\
3.3 \\
2.8 \\
2.8 \\
2.8\end{array}$ \\
\hline $\begin{array}{l}\frac{\text { GS-8A }}{69 \% \text { Sand }} \\
26 \% \text { Silt } \\
5 \% \text { Clay }\end{array}$ & $\begin{array}{l}2.0 \mathrm{E}+3 \\
1.0 \mathrm{E}+3 \\
5 \cdot 0 \mathrm{E}+2 \\
2 \cdot 5 \mathrm{E}+2 \\
1.1 \mathrm{E}+2 \\
7 \cdot 5 \mathrm{E}+1 \\
5.3 \mathrm{E}+1 \\
4 \cdot 8 \mathrm{E}+1 \\
2 \cdot 8 \mathrm{E}+1 \\
1.6 \mathrm{E}+1 \\
9.3 \mathrm{E}+0 \\
6 \cdot 5 \mathrm{E}+0 \\
5 \cdot 3 \mathrm{E}+0 \\
4 \cdot 6 \mathrm{E}+0 \\
1.3 \mathrm{E}+0\end{array}$ & $\begin{array}{l}98.0 \\
92.3 \\
62.9 \\
51.3 \\
42.9 \\
37.4 \\
31.2 \\
25.3 \\
17.5 \\
12.3 \\
8.0 \\
7.3 \\
5.5 \\
5.3 \\
5.0\end{array}$ & $\begin{array}{l}\frac{\text { GS-BD }}{71 \% \text { Sand }} \\
24 \% \text { Silt } \\
5 \% \text { Clay }\end{array}$ & $\begin{array}{l}2.0 E+3 \\
1.0 E+3 \\
5.0 E+2 \\
2.5 E+2 \\
1.1 E+2 \\
7.5 E+1 \\
5.3 E+1 \\
4.9 E+1 \\
2.9 E+1 \\
1.6 E+1 \\
9.1 E+0 \\
6.6 E+0 \\
5.4 E+0 \\
4.6 E+0 \\
1.4 E+0\end{array}$ & $\begin{array}{r}100.0 \\
97.8 \\
59.2 \\
46.9 \\
39.2 \\
34.9 \\
30.0 \\
26.0 \\
17.1 \\
11.4 \\
7.9 \\
6.7 \\
6.3 \\
6.0 \\
4.7\end{array}$ \\
\hline
\end{tabular}


TABLE 6.2. (contd)

\begin{tabular}{|c|c|c|c|c|c|}
\hline Sample ID & $\begin{array}{c}\text { Particle Size } \\
\text { (microns) }\end{array}$ & $\%$ Less Than & Sample ID & $\begin{array}{c}\text { Particle Size } \\
\text { (microns) }\end{array}$ & $\%$ Less Than \\
\hline $\begin{array}{l}\frac{G S-9 A}{76 \% \text { Sand }} \\
20 \% \text { S i I t } \\
4 \% \text { C I ay }\end{array}$ & $\begin{array}{l}2.0 \mathrm{E}+3 \\
1.0 \mathrm{E}+3 \\
5.0 \mathrm{E}+2 \\
2.5 \mathrm{E}+2 \\
1.1 \mathrm{E}+2 \\
7.5 \mathrm{E}+1 \\
5.3 \mathrm{E}+1 \\
4.9 \mathrm{E}+1 \\
2.9 \mathrm{E}+1 \\
1.6 \mathrm{E}+1 \\
9.2 \mathrm{E}+0 \\
6.5 \mathrm{E}+0 \\
5.3 \mathrm{E}+0 \\
4.6 \mathrm{E}+0 \\
1.3 \mathrm{E}+0\end{array}$ & $\begin{array}{l}98.7 \\
96.6 \\
53.4 \\
37.1 \\
32.1 \\
28.4 \\
24.4 \\
18.5 \\
14.0 \\
10.0 \\
7.3 \\
6.0 \\
5.0 \\
5.0 \\
3.8\end{array}$ & $\begin{array}{l}\frac{\text { GS }-9 B}{91 \% \text { Sand }} \\
6 \% \text { S i I t } \\
3 \% \text { Clay }\end{array}$ & $\begin{array}{l}2.0 \mathrm{E}+3 \\
1.0 \mathrm{E}+3 \\
5.0 \mathrm{E}+2 \\
2.5 \mathrm{E}+2 \\
1.1 \mathrm{E}+2 \\
7.5 \mathrm{E}+1 \\
5.3 \mathrm{E}+1 \\
5.0 \mathrm{E}+1 \\
2.9 \mathrm{E}+1 \\
1.6 \mathrm{E}+1 \\
9.3 \mathrm{E}+0 \\
6.6 \mathrm{E}+0 \\
5.4 \mathrm{E}+0 \\
4.6 \mathrm{E}+0 \\
1.4 \mathrm{E}+0\end{array}$ & $\begin{array}{l}99.7 \\
95.0 \\
40.1 \\
14.1 \\
11.1 \\
9.9 \\
9.1 \\
6.3 \\
5.3 \\
4.8 \\
3.3 \\
2.8 \\
2.5 \\
2.5 \\
2.5\end{array}$ \\
\hline $\begin{array}{l}\text { GS-10A } \\
73 \% \text { Sand } \\
22 \% \text { S i I t } \\
5 \% \text { Clay }\end{array}$ & $\begin{array}{l}2.0 \mathrm{E}+3 \\
1.0 \mathrm{E}+3 \\
5.0 \mathrm{E}+2 \\
2.5 \mathrm{E}+2 \\
1.1 \mathrm{E}+2 \\
7.5 \mathrm{E}+1 \\
5.3 \mathrm{E}+1 \\
4.9 \mathrm{E}+1 \\
2.9 \mathrm{E}+1 \\
1.6 \mathrm{E}+1 \\
9.3 \mathrm{E}+0 \\
6.6 \mathrm{E}+0 \\
5.4 \mathrm{E}+0 \\
4.6 \mathrm{E}+0 \\
1.4 \mathrm{E}+0\end{array}$ & $\begin{array}{r}100.0 \\
97.4 \\
50.0 \\
39.5 \\
34.0 \\
30.0 \\
25.4 \\
22.3 \\
17.0 \\
12.6 \\
9.8 \\
8.3 \\
7.4 \\
6.9 \\
5.7\end{array}$ & & & \\
\hline
\end{tabular}


TABLE B.3. Particle-Size Distribution Data from the McGee Ranch Site

\begin{tabular}{|c|c|c|c|c|c|}
\hline$\underline{\text { Sample } \mathbb{D}}$ & $\begin{array}{c}\text { Particle Size } \\
\text { (microns) }\end{array}$ & $\%$ Less Than & Sample $\mathbb{D}$ & $\begin{array}{c}\text { Particle Size } \\
\text { (microns) }\end{array}$ & $\%$ Less Than \\
\hline $\begin{array}{l}\frac{M C G-1 A}{41 \% \text { Sand }} \\
42 \% \text { S i it } \\
17 \% \text { Clay }\end{array}$ & $\begin{array}{l}2.0 \mathrm{E}+3 \\
1.0 \mathrm{E}+3 \\
5.0 \mathrm{E}+2 \\
2.5 \mathrm{E}+2 \\
1.1 \mathrm{E}+2 \\
7.5 \mathrm{E}+1 \\
5.3 \mathrm{E}+1 \\
4 \cdot 4 \mathrm{E}+1 \\
2.7 \mathrm{E}+1 \\
1.5 \mathrm{E}+1 \\
8 \cdot 8 \mathrm{E}+0 \\
6 \cdot 3 \mathrm{E}+0 \\
5 \cdot 1 \mathrm{E}+0 \\
4 \cdot 5 \mathrm{E}+0 \\
1.3 \mathrm{E}+0\end{array}$ & $\begin{array}{r}100.0 \\
99.3 \\
97.3 \\
95.8 \\
86.9 \\
70.4 \\
59.5 \\
60.0 \\
45.0 \\
35.0 \\
28.8 \\
23.3 \\
21.3 \\
20.0 \\
15.8\end{array}$ & $\begin{array}{l}\frac{M C G-1 B}{53 \% \text { Sand }} \\
32 \% \text { S i lt } \\
15 \% \text { Clay }\end{array}$ & $\begin{array}{l}2.0 \mathrm{E}+3 \\
1.0 \mathrm{E}+3 \\
5.0 \mathrm{E}+2 \\
2.5 \mathrm{E}+2 \\
1.1 \mathrm{E}+2 \\
7 \cdot 5 \mathrm{E}+1 \\
5.3 \mathrm{E}+1 \\
4 \cdot 5 \mathrm{E}+1 \\
2 \cdot 7 \mathrm{E}+1 \\
1 \cdot 5 \mathrm{E}+1 \\
9.0 \mathrm{E}+0 \\
6 \cdot 3 \mathrm{E}+0 \\
5 \cdot 2 \mathrm{E}+0 \\
4 \cdot 5 \mathrm{E}+0 \\
1.3 \mathrm{E}+0\end{array}$ & $\begin{array}{r}100.0 \\
99.8 \\
98.7 \\
96.3 \\
80.6 \\
59.1 \\
46.6 \\
50.0 \\
35.0 \\
27.3 \\
22.0 \\
19.0 \\
17.5 \\
17.0 \\
14.5\end{array}$ \\
\hline $\begin{array}{l}\frac{M C G-2 A}{35 \% \text { Sand }} \\
57 \% \text { S i l t } \\
8 \% \text { C lay }\end{array}$ & $\begin{array}{l}2 \cdot 0 \mathrm{E}+3 \\
1 \cdot 0 \mathrm{E}+3 \\
5 \cdot 0 \mathrm{E}+2 \\
2 \cdot 5 \mathrm{E}+2 \\
1 \cdot 1 \mathrm{E}+2 \\
7 \cdot 5 \mathrm{E}+1 \\
5 \cdot 3 \mathrm{E}+1 \\
4 \cdot 4 \mathrm{E}+1 \\
2 \cdot 7 \mathrm{E}+1 \\
1 \cdot 5 \mathrm{E}+1 \\
9 \cdot 0 \mathrm{E}+0 \\
6 \cdot 4 \mathrm{E}+0 \\
5 \cdot 2 \mathrm{E}+0 \\
4 \cdot 6 \mathrm{E}+0 \\
1 \cdot 3 \mathrm{E}+0\end{array}$ & $\begin{array}{r}100.0 \\
99.8 \\
98.8 \\
96.9 \\
89.6 \\
75.9 \\
64.8 \\
58.8 \\
41.3 \\
27.5 \\
19.3 \\
14.8 \\
12.5 \\
11.0 \\
7.3\end{array}$ & $\begin{array}{l}\frac{M C G-2 B}{7 \% \text { Sand }} \\
75 \% \text { S i l t } \\
18 \% \text { Clay }\end{array}$ & $\begin{array}{l}2.0 \mathrm{E}+3 \\
1 \cdot 0 \mathrm{E}+3 \\
5 \cdot 0 \mathrm{E}+2 \\
2.5 \mathrm{E}+2 \\
1.1 \mathrm{E}+2 \\
7 \cdot 5 \mathrm{E}+1 \\
5.3 \mathrm{E}+1 \\
4.1 \mathrm{E}+1 \\
2 \cdot 5 \mathrm{E}+1 \\
1.4 \mathrm{E}+1 \\
8.5 \mathrm{E}+0 \\
6 \cdot 1 \mathrm{E}+0 \\
5 \cdot 1 \mathrm{E}+0 \\
4 \cdot 4 \mathrm{E}+0 \\
1.3 \mathrm{E}+0\end{array}$ & $\begin{array}{r}100.0 \\
100.0 \\
99.9 \\
99.6 \\
97.8 \\
94.8 \\
92.6 \\
85.0 \\
73.8 \\
60.0 \\
44.0 \\
33.8 \\
28.0 \\
25.3 \\
14.0\end{array}$ \\
\hline $\begin{array}{l}\frac{\text { MCG-3A }}{44 \% \text { Sand }} \\
37 \% \text { S i l t } \\
19 \% \text { Clay }\end{array}$ & $\begin{array}{l}2.0 \mathrm{E}+3 \\
1.0 \mathrm{E}+3 \\
5 \cdot 0 \mathrm{E}+2 \\
2 \cdot 5 \mathrm{E}+2 \\
1.1 \mathrm{E}+2 \\
7 \cdot 5 \mathrm{E}+1 \\
5.3 \mathrm{E}+1 \\
4 \cdot 4 \mathrm{E}+1 \\
2 \cdot 7 \mathrm{E}+1 \\
1.5 \mathrm{E}+1 \\
8 \cdot 9 \mathrm{E}+0 \\
6.2 \mathrm{E}+0 \\
5 \cdot 1 \mathrm{E}+0 \\
4 \cdot 4 \mathrm{E}+0 \\
1.3 \mathrm{E}+0\end{array}$ & $\begin{array}{l}99.9 \\
99.7 \\
98.2 \\
92.9 \\
75.8 \\
64.2 \\
56.1 \\
58.3 \\
44.0 \\
35.0 \\
25.8 \\
25.0 \\
22.5 \\
22.0 \\
17.5\end{array}$ & $\begin{array}{l}\frac{\text { MCG-3B }}{33 \% \text { Sand }} \\
53 \% \text { S i l t } \\
14 \% \text { Clay }\end{array}$ & $\begin{array}{l}2 \cdot 0 \mathrm{E}+3 \\
1 \cdot 0 \mathrm{E}+3 \\
5 \cdot 0 \mathrm{E}+2 \\
2 \cdot 5 \mathrm{E}+2 \\
1 \cdot 1 \mathrm{E}+2 \\
7 \cdot 5 \mathrm{E}+1 \\
5 \cdot 3 \mathrm{E}+1 \\
4 \cdot 4 \mathrm{E}+1 \\
2 \cdot 7 \mathrm{E}+1 \\
1 \cdot 5 \mathrm{E}+1 \\
9 \cdot 0 \mathrm{E}+0 \\
6 \cdot 3 \mathrm{E}+0 \\
5 \cdot 2 \mathrm{E}+0 \\
4 \cdot 5 \mathrm{E}+0 \\
1 \cdot 3 \mathrm{E}+0\end{array}$ & $\begin{array}{r}100.0 \\
100.0 \\
100.0 \\
99.7 \\
95.4 \\
80.4 \\
67.5 \\
63.8 \\
45.0 \\
31.3 \\
24.0 \\
20.0 \\
17.8 \\
17.0 \\
13.0\end{array}$ \\
\hline
\end{tabular}


TABLE B.3. (contd)

\begin{tabular}{|c|c|c|c|c|c|}
\hline Sample ID & $\begin{array}{c}\text { Particle Size } \\
\text { (microns) }\end{array}$ & $\%$ Less Than & Sample ID & $\begin{array}{c}\text { Particle Size } \\
\text { (microns) }\end{array}$ & $\%$ Less Than \\
\hline \begin{tabular}{ll}
\multicolumn{2}{c}{ MCG-4A } \\
$45 \%$ & Sand \\
$38 \%$ & Silt \\
$17 \%$ & Clay
\end{tabular} & $\begin{array}{l}2 \cdot 0 \mathrm{E}+3 \\
1.0 \mathrm{E}+3 \\
5 \cdot 0 \mathrm{E}+2 \\
2 \cdot 5 \mathrm{E}+2 \\
1.1 \mathrm{E}+2 \\
7 \cdot 5 \mathrm{E}+1 \\
5 \cdot 3 \mathrm{E}+1 \\
4 \cdot 5 \mathrm{E}+1 \\
2 \cdot 7 \mathrm{E}+1 \\
1.5 \mathrm{E}+1 \\
8 \cdot 9 \mathrm{E}+0 \\
6 \cdot 3 \mathrm{E}+0 \\
5 \cdot 2 \mathrm{E}+0 \\
4 \cdot 5 \mathrm{E}+0 \\
1 \cdot 3 \mathrm{E}+0\end{array}$ & $\begin{array}{r}100.0 \\
99.8 \\
96.7 \\
93.5 \\
77.8 \\
63.8 \\
55.0 \\
54.5 \\
41.0 \\
32.5 \\
25.5 \\
22.5 \\
20.0 \\
19.5 \\
16.3\end{array}$ & \begin{tabular}{ll}
\multicolumn{2}{c}{ MCG-4B } \\
$28 \%$ & Sand \\
$55 \%$ & Silt \\
$17 \%$ & Clay
\end{tabular} & $\begin{array}{l}2.0 E+3 \\
1.0 E+3 \\
5.0 E+2 \\
2.5 E+2 \\
1.1 E+2 \\
7.5 E+1 \\
5.3 E+1 \\
4.3 E+1 \\
2.6 E+1 \\
1.5 E+1 \\
8.8 E+0 \\
6.2 E+0 \\
5.1 E+0 \\
4.5 E+0 \\
1.3 E+0\end{array}$ & $\begin{array}{c}100.0 \\
100.0 \\
97.9 \\
95.8 \\
91.2 \\
81.5 \\
72.5 \\
70.0 \\
53.3 \\
39.5 \\
29.8 \\
24.0 \\
21.3 \\
20.0 \\
14.8\end{array}$ \\
\hline \begin{tabular}{ll}
\multicolumn{2}{c}{ MCG-9A } \\
$35 \%$ & Sand \\
$54 \%$ & Silt \\
$11 \%$ & Clay
\end{tabular} & $\begin{array}{l}2.0 \mathrm{E}+3 \\
1.0 \mathrm{E}+3 \\
5.0 \mathrm{E}+2 \\
2.5 \mathrm{E}+2 \\
1.1 \mathrm{E}+2 \\
7.5 \mathrm{E}+1 \\
5.3 \mathrm{E}+1 \\
4.5 \mathrm{E}+1 \\
2.7 \mathrm{E}+1 \\
1.5 \mathrm{E}+1 \\
9.0 \mathrm{E}+0 \\
6.4 \mathrm{E}+0 \\
5.1 \mathrm{E}+0 \\
4.5 \mathrm{E}+0 \\
1.3 \mathrm{E}+0\end{array}$ & $\begin{array}{r}100.0 \\
99.8 \\
98.6 \\
96.7 \\
87.8 \\
76.2 \\
63.8 \\
56.1 \\
40.6 \\
31.6 \\
23.1 \\
18.1 \\
15.4 \\
14.8 \\
8.9\end{array}$ & \begin{aligned} & \multicolumn{2}{c}{ MCG-9B } \\
& $43 \%$ Sand \\
& $51 \%$ Silt \\
& $6 \%$ Clay \end{aligned} & $\begin{array}{l}2.0 \mathrm{E}+3 \\
1.0 \mathrm{E}+3 \\
5.0 \mathrm{E}+2 \\
2.5 \mathrm{E}+2 \\
1.1 \mathrm{E}+2 \\
7.5 \mathrm{E}+1 \\
5.3 \mathrm{E}+1 \\
4.6 \mathrm{E}+1 \\
2.8 \mathrm{E}+1 \\
1.6 \mathrm{E}+1 \\
9.2 \mathrm{E}+0 \\
6.5 \mathrm{E}+0 \\
5.3 \mathrm{E}+0 \\
4.6 \mathrm{E}+0 \\
1.3 \mathrm{E}+0\end{array}$ & $\begin{array}{r}100.0 \\
99.9 \\
98.9 \\
97.7 \\
90.4 \\
78.0 \\
48.8 \\
49.1 \\
25.3 \\
15.9 \\
10.5 \\
8.1 \\
7.4 \\
7.1 \\
5.4\end{array}$ \\
\hline $\begin{aligned} & M C G-10 A \\
& 48 \% \text { Sand } \\
& 46 \% \text { Silt } \\
& 6 \% \text { Clay }\end{aligned}$ & $\begin{array}{l}2.0 \mathrm{E}+3 \\
1.0 \mathrm{E}+3 \\
5.0 \mathrm{E}+2 \\
2.5 \mathrm{E}+2 \\
1.1 \mathrm{E}+2 \\
7.5 \mathrm{E}+1 \\
5.3 \mathrm{E}+1 \\
4.6 \mathrm{E}+1 \\
2.8 \mathrm{E}+1 \\
1.6 \mathrm{E}+1 \\
9.1 \mathrm{E}+0 \\
6.5 \mathrm{E}+0 \\
5.3 \mathrm{E}+0 \\
4.6 \mathrm{E}+0 \\
1.3 \mathrm{E}+0\end{array}$ & $\begin{array}{l}99.7 \\
98.8 \\
94.9 \\
91.5 \\
80.1 \\
66.8 \\
52.4 \\
45.1 \\
28.3 \\
19.6 \\
12.8 \\
10.3 \\
9.3 \\
8.3 \\
6.3\end{array}$ & $\begin{array}{rr}\text { MCG-10B } \\
48 \% & \text { Sand } \\
47 \% & \text { Silt } \\
5 \% & \text { Cl ay }\end{array}$ & $\begin{array}{l}2.0 \mathrm{E}+3 \\
1.0 \mathrm{E}+3 \\
5.0 \mathrm{E}+2 \\
2.5 \mathrm{E}+2 \\
1.1 \mathrm{E}+2 \\
7.5 \mathrm{E}+1 \\
5.3 \mathrm{E}+1 \\
4.6 \mathrm{E}+1 \\
2.8 \mathrm{E}+1 \\
1.6 \mathrm{E}+1 \\
9.2 \mathrm{E}+0 \\
6.5 \mathrm{E}+0 \\
5.3 \mathrm{E}+0 \\
4.6 \mathrm{E}+0 \\
1.3 \mathrm{E}+0\end{array}$ & $\begin{array}{r}99.5 \\
99.5 \\
97.3 \\
95.4 \\
87.8 \\
70.7 \\
51.7 \\
43.8 \\
24.4 \\
14.9 \\
9.8 \\
7.4 \\
6.1 \\
5.1 \\
4.6\end{array}$ \\
\hline
\end{tabular}




\section{DISTRIBUTION}

No. of

Copies

OFFSITE

10 DOE/Office of Scientific and Technical Information Center

6 DOE Office of Civilian

Radioactive Waste Management Forrestal Building

Washington, DC 20585

ATTN: L. H. Barrett, RW-33

C. R. Cooley, RW-40

J. R. Hilley, RW-30

S. H. Kale, RW-20

D. E Shelor, RW-32

R. Stein, RW-23

4 DOE Office of Defense Waste \& GTN

Washington, DC 20545

ATTN: T. C. Chee, DP-123

K. A. Chorey, DP-123

G. H. Daly, DP-124

J. E. Lytle, DP-124

4 DOE Office of Remedial Action GTN

\& Waste Technology

Washington, DC 20545

ATTN: J. A. Coleman, NE-24

T. W. McIntosh, NE-24

W. R. Voight, NE-20

H. F. Walter, NE-24

3 DOE Idaho Operations Office

550 Second Street

Idaho Falls, ID 83401

ATTN: J. P. Hamric

S. T. Hinschberger

J. L. Lyle
No. of

$\underline{\text { Copies }}$

W. J. Brumley

DOE Savannah River Operations Office

P.O. Box A

Aiken, SC 29801

F. T. Fong

DOE San Francisco Operations

1333 Broadway

Oakland, CA 94612

M. R. Jugan

DOE Oak Ridge Operations Office

P.O. Box E

Oak Ridge, TN 37830

E. Maestas

DOE West Valley Project Office

P.O. Box 191

West Valley, NY 14171

J. M. McGough

DOE Albuquerque Operations Office

P.O. Box 5400

Albuquerque, NM 87185

C. S. Abrams

Argonne National Laboratory

P.O. Box 2528

Idaho Falls, ID 83401

Battelle Memorial Institute

Project Management Division

505 King Avenue

Columbus, $\mathrm{OH} 43201$

ATTN: W. A. Carbeiner

W. S. Madia

Technical Library 
No. of

$\underline{\text { Copies }}$

Paul Bembia

U.S. Nuclear Regulatory Commission

Geochemical Section

Mail Stop 62355

Washington, D.C. 20555

J. R. Berreth

Westinghouse Idaho Nuclear Co., Inc.

P.O. Box 4000

Idaho Falls, ID 83401

W. Brewer

Office of High-Level Nuclear Waste Management

Washington State Department of Ecology

Mail Stop PV-11

Olympia, WA 98504

G. S. Campbell

Agronomy Department

Washington State University

Pullman, WA 99164

\section{A. T. Clark}

Division of Fuel Material Safety

Nuclear Regulatory Commission

Washington, DC 20555

G. A. Dinwiddie

U. S. Geological Survey 12201 Sunrise Valley Drive

Reston, VA 22092

E. I _ du Pont de Nemours Company

Savannah River Plant

Building 704S

Aiken, SC 29808

ATTN: R. G. Baxter

M. D. Boersma

J. G. Glasscock

J. R. Knight

M. J. Plodinec

C. T. Randal 1
No. of

Copies

J. Fischer

Low-Level Radioactive Waste

Program

U.S. Geological Survey

Water Resources Division

12201 Sunrise Valley Drive

Reston, VA 22092

L. Frank

Department of Energy

625 Marion Street, N.E.

Salem, OR 97310

P. G. Hagan

Joint Integration Office

Carlmont Executive 1

4308 Carlisle N.E.

Albuquerque, NM 87107

T. E. Hakonson

Los Alamos National Laboratory

P.O. Box 1663

Los Alamos, NM 87545

D. Hillel

Department of Plant and Soil Science

$12 \mathrm{~A}$ Stockbridge Hall

University of Massachusetts

Amherst, MA 01003

E. A. Jennrich

EG\&G Idaho

P.O. Box 1625

Idaho Falls, ID 83415

W. A. Jury

Department of Soils

University of California

at Riverside

Riverside, CA 92502

D. A. Knecht

Westinghouse Idaho Nuclear Company

P.O. Box 4000

Idaho Falls, ID 83403 
No. of $\underline{\text { Copies }}$

S. Meyers

Environmental Protection Agency

Office of Radiation Programs (ANR-458)

$401 \mathrm{M}$ Street S.W.

Washington, DC 20460

T. J. Nicholson

U.S. Nuclear Regulatory Commission

Div. of Engineering Safety

MS NL-005

Washington, DC 20555

J. W. Nyhan

Los Alamos National Laboratory

P.O. Box 1663

Los Alamos, NM 87545

Oak Ridge National Laboratory

P.O. Box Y

Oak Ridge, TN 37830

ATTN: J. 0. Blomeke

W. D. Burch

R. T. Jubin

L. J. Mezga

D. T. Oakley, MS 619

Los Alamos Scientific Laboratory

P.O. Box 1663

Los Alamos, NM 87544

E. O'Donnel1

Earth Sciences Branch

Division of Health, Siting and Waste Management Research

U. S. Nuclear Regulatory Commis sion

Washington, DC 20555

L. D. Ramspott

Lawrence Livermore National Laboratory

University of California

P.O. Box 808

Livermore, CA 94550
No. of

Copies

J. Rensel

High-Level Waste Management

Washington State Department of Ecology

Mail Stop Pu II

Olympia, WA 98504

E. M. Romney

Laboratory of Biomedical and Environmental Sciences

University of California at Los Angeles

Los Angeles, CA 90024

Sandia Laboratories

P.O. Box 5800

Albuquerque, NM 87185

ATTN: R. W. Lynch

Technical Library

R. Shaw

Electric Power Research

Institute

3412 Hillview Avenue

P.O. Box 10412

Palo Alto, CA 94304

R. Stanley

Supervisor Hanford Section

Washington State Department of Ecology

Mail Stop PV-11

Olympia, WA 98504

M. J. Steindler

Argonne National Laboratory

9700 South Cass Avenue

Argonne, IL 60439

V. Stello

Office of the Executive Director for Operations

Mail Station 6209

Nuclear Regulatory Commission

Washington, DC 20555 
No. of

Copies

D. Stephens

Dept. of Geosciences

New Mexico Institute of Mining and Technology

Socorro, NM 87801

S. Tyler

Desert Research Institute

P.O. Box 60220

Reno, NV 89506

E. P. Weeks

U.S. Geological Survey

Federal Center Mail Stop 413

Denver, CO 80225

West Valley Nuclear Services Company

P.O. Box 191

West Valley, NY 14171

ATTN: C. C. Chapman

J. C. Cwynar

J. E. Krauss

S. J. Marchette

J. M. Pope

J. L. White, Chairman

Energy Research \& Development Authority

Empire State Plaza

Albany, NY 12223

P. J. Wierenga

Dept. of Soil Science

New Mexico State University

Las Cruces, NM 88004

I J. Winograd

U. S. Geological Survey

National Center - Mail Stop 432

Reston, VA 22092

\section{ONSITE}

7 DOE Richland Operations Office

E. A Bracken

G. J. Bracken

R. D. Gerton

R. D. Izatt
No. of

$\underline{\text { Copies }}$
J. M. Peterson
G. W. Rosenwald
M. W. Shupe

18 Westinghouse Hanford Company

M R. Adams

T. B. Bergman

L. C. Brown

J. W. Cammann

R. A Carlson

J. D. Davis

C. DeFigh-Price

C. J. Geier

D. S. Landeen

R. E. Lerch

H. E McGuire

K. W. Owens

S. J. Phillips

J. F. Relyea

W. W. Schulz

N. R. Wing

D. D. Wodrich

R. D. Wojtasek

56 Pacific Northwest Laboratory

W. W. Ballard, Jr.

P. A. Beedlow

L. L. Cadwe 11

M. D. Campbell

J. W. Cary

J. L. Downs

D. W. Dragnich

M. J. Fayer (5)

M. G. Foley

H. D. Freeman

G. W. Gee

S. M. Goodwin

M. J. Graham

J. M. Hales

P. C. Hays

P. R. Heller

T. L. Jones

C. T. Kincaid

R. R. Kirkham

G. V. Last

M. W. Ligotke

S. 0. Link 
No. of

Copies

J. F. McBride

J. I. McElroy

D. H. Mitchell

E. M. Murphy

R. W. Nelson

M. L. Rockhold (10)

L. E. Roger

B. Sagar
No. of

Copies

C. S. Simmons

R. L. Skaggs

J. A. Stottlemyre

G. P. Streile

R. L. Treat

R. E. Wildung

Publishing Coordination (2)

Technical Report Files (5) 